\title{
STRATEGIES IN UNDERWRITING THE COSTS OF CATASTROPHIC DISEASE*
}

\author{
Clark C. Havighurst $\dagger$, \\ James F. Blumstein $\dagger$, \\ \& RANDALL BovBJERG $\dagger+\dagger$
}

\section{INTRODUCTION}

"Catastrophic" illness has recently been recognized as a major problem of public policy. Diseases may be considered "catastrophic" for policy purposes simply because of their calamitous nature or because of their high treatment costs. Early steps extending protection against catastrophic illness were confined to identifying specific diseases as catastrophic so as to concentrate governmental efforts on a limited class of patients; ${ }^{1}$ the advantage of this categorical approach was the greater control that it provided over the government's financial commitment, which could be gradually expanded as political pressures built on behalf of new diseases and as resources became available. Now, however, concern about catastrophic illness seems to be focused not on specific diseases but on the general hazard of financial disaster associated with high health care costs. A patient's disease is considered catastrophic in this sense only if it is extraordinarily expensive to treat. Thus, contrary to popular

* Work on this article was supported by grant number HS 01539 from the National Center for Health Services Research, U.S. Department of Health, Education and Welfare, by the Vanderbilt Institute for Public Policy Studies, and by the Department of Community Medicine of Dartmouth Medical School. The authors gratefully acknowledge the editorial assistance of Peter C. Buck, I.D., 1976, Duke University School of Law, Member of the North Carolina Bar, and the research assistance of Andrew Shookhoff, J.D., 1977, and Craig Gabbert, J.D., 1976, Vanderbilt Law School.

$\dagger$ Professor of Law and Director, Program on Legal Issues in Health Care, Duke University.

$\dagger \dagger$ Professor of Law, Vanderbilt University.

$\dagger \dagger \dagger$ Research Attorney, Program on Legal Issues in Health Care, Duke University.

1. In 1965, Congress enacted disease-specific legislation aimed at improving care for heart disease, cancer, and strokes. Heart Disease, Cancer, and Stroke Amendments of 1965, Pub. L. No. 89-239, 79 Stat. 926 [codified at 42 U.S.C. $\S \S 299-299 i(1970)$ ]. In 1969, Congress voted to assist miners suffering from another specific disease, "black lung" (pneumoconiosis), Federal Coal Mine Health \& Safety Act of 1969, P.L. 91-173, 83 Stat. 792 [codified at 30 U.S.C. $\$ \S 901-36$ (1970)], an effort continued by the 1972 black lung amendments, Black Lung Benefits Act of 1972, P.L. 92-303, 86 Stat. 153 [codified at 30 U.S.C. $\$ 901-41$ (Supp. IV 1974)]. See generally Usery v. Turner Elkhorn Mining Co., 428 U.S. 1 (1976) (upholding black lung amendments). In 1972, most victims of end-stage kidney disease were brought under Medicare. Social Security Amendments of 1972, P.L. 92-603, § 299I, 86 Stat. 1463, 42 U.S.C. $\S 426$ (f)- $\$ 426$ (g) (Supp. IV 1974). See generally Rettig, Valuing Lives: The Policy Debate on Patient Care Financing for Victims of End-Stage Renal Disease, 40 LAw \& Contemp. Prob. 196 (1976). The disease-by-disease approach, however, has been extensively criticized. See Office of the Ass't. Sec'y for Planning and Evaluation, Dep't of Health, Educ. and Welfare, Task Force Report on Catastrophic Illnesses and Costs (W. Herman, director, May 1971) [hereinafter cited as Catastrophic Illnesses and Costs]; INSTITUTE OF Medicine, National Academy of Sciences, Disease by Disease Toward National Health Insurance? (Panel Report, June 1973). 
usage, a sudden fatal heart attack would not be deemed catastrophic, while a chronic but nonfatal condition might be-if the accepted therapy or rehabilitative regimen were very costly. ${ }^{2}$ Medical costs have risen in recent years significantly faster than the rate of general inflation, ${ }^{3}$ so that many illnesses, including some that were previously untreatable, now threaten bankruptcy, even for persons covered by private insurance or government programs. Resulting public concern has given rise to a variety of proposals to transfer more, or even all, of the costs of catastrophic illness from individuals and families to a deeper pocket, either a private insurance fund or a government financing program.

The thesis of this article is that, although there are good reasons for our society to seek to spare its individual members catastrophic health care costs, in doing so it will almost inevitably commit more resources than it really wants to commit, ${ }^{4}$ or should commit, ${ }^{5}$ to such a purpose. This result is probable

2. Our discussion will focus primarily on life-threatening or terminal illnesses rather than on chronic diseases, since lifesaving efforts illustrate most graphically the major financing problem-the difficulty of setting the appropriate level of funding, especially where government financing is available. Long-term care for those with nonfatal chronic illness, on the other hand, may be quite expensive, and if a government program defines illnesses as "catastrophic" according to their cost, it will probably be more concerned with chronic than with life-threatening cases. See Congressional Budget Office, Catastrophic Health Insurance 9 (Budget Issue Paper, Jan. 1977) [hereinafter cited as CBO Issue Paper] ("long term care . . . is the most frequent cause of catastrophic expense.") Because long-term care as presently understood includes a host of services-both in and out of institutions-not traditionally considered medical, see Murnaghan, Review of the Conference Proceedings, 14 MED. Care, Supp., May 1976, at 1 (1976), cost control is especially difficult, and family bankruptcy may be induced by more problems than meeting medical bills.

3. See, e.g., Council on Wage and Price Stability, Executive Office of the President, The Problem of Rising Health Care Costs (Staff Report, April 1976).

4. The notion that a democratic society's collective decision on catastrophic health insurance might cause unintended overspending may strike some as a contradiction, since in theory the legislature accurately represents societal desires. But, even though a democratic legislature speaks for the people in some general sense, it is capable of creating conditions under which serious and largely unintended misallocations of resources can occur. Uncritical acceptance of the allocative consequences of a democratic process is comparable to blind faith in the invisible hand of a laissez-faire marketplace. See T. Lowi, The End of Liberalism 294-97 (1969). See also J. Buchanan \& G. Tullock, The Calculus of Consent (1962).

5. The normative benchmark applied here is the hypothetical optimal allocation of resources which would result from the purchasing decisions of reasonable and knowledgeable individuals (none with less than a specified income) in a smoothly functioning marketplace for both insurance and medical care. See Havighurst \& Blumstein, Coping with Quality/Cost Trade-Offs in Medical Care: The Role of PSRO's, 70 Nw. U.L. Rev. 6, 15-20 \& nn. 35, 36, 45 (1975). This notion primarily illustrates the distorting effect of third-party payment for medical care, but it also reveals "the enormity of the practical problem presented and the social and political dynamics of [attempting to achieve optimality] through nonmarket mechanisms." Id. at $6 \mathrm{n} .1$. The general idea that health policy should strive for providing a "decent minimum" rather than everything possible, or all that might be desired, or perfect equality, has recently been well stated by Professor Charles Fried, who nevertheless stops short of considering how the necessary lines can or should be drawn. Fried, Equality and Rights in Medical Care, in Instrtute of Medicine, National Academy of Sciences, Implications of Guaranteeing Medical Care 3 (J. Perpich ed. 1975). See also Rosenthal, Setting the Floor: A Missing Ingredient in an Effective Health Policy, $1 \mathrm{~J}$. Health Politics, Policy \& LAw 2 (1976). 
because government will find it difficult to impose, or even tolerate, needed limits on very expensive medical efforts to save lives and preserve health without seeming to deny the sanctity of human life. The challenge is thus to design social institutions which neither unduly sacrifice society's humanitarian ideals nor overspend on medical services not warranted by the benefits they yield. It is our view that government cannot safely assume too central a role in decisionmaking on life-and-death and similar issues and that society will be better off if institutional arrangements are such that death and suffering from catastrophic disease continue to be perceived as "more an act of God than of the legislature." 6 Careful attention to program details and to the allocation of decisionmaking responsibility is necessary if society is to succeed, in the context of expanded protection against catastrophic medical expenses, in preserving both humanitarian values and democratic government's benign-if not its beneficent-image.

This article reviews current and proposed efforts to help those faced with catastrophic medical expenses, focusing particularly on methods of containing program costs. It identifies a critical need to keep government's profile low in order to facilitate saying "no" when it is appropriate to do so. In examining some possible techniques for doing this, the article seeks to help government limit its moral as well as its financial exposure while honoring a substantial commitment to assist victims of catastrophic disease.

Present Coverage of Catastrophic Medical Expense

\section{A. Private Health Insurance}

Health care expenditures-particularly when catastrophically high-are a classic example of the type of risk people attempt to insure against. By the very nature of illness and accident, most people are unsure of the future state of their health and their prospective demand for medical services and must protect themselves against an unexpected medical-financial calamity. Rational consumers can therefore be expected to purchase insurance as a means of converting unpredictable, episodic medical expenses into fixed periodic premiums and of pooling their risks with others in roughly similar circumstances. ${ }^{7}$ Further incentive to purchase insurance comes from the rapidly rising cost and sophistication of medical care itself (which increase potential costs and in-

6. Artificial Heart assessment Panel, Nat'l Heart \& Lung inst., The Totally Implantable Artificial Heart 247 (DHEW Pub. No. (NIH) 74-191, 1973) (separate views of C. Havighurst).

7. See generally Arrow, Uncertainty and the Welfare Economics of Medical Care, 53 Am. Econ. Rev. 941 (1963). 
surable risks) ${ }^{8}$ and from tax subsidies (which decrease the net premium). ${ }^{9}$

Most Americans are in fact covered by some form of private health care insurance. In 1974, over three-quarters of the population had substantial economic protection through private health insurance against the expenses of hospital and surgical care, including in-hospital physician visits, whereas a generation ago, comparatively few had such protection. ${ }^{10}$ Although the population covered is broad and growing, a major drawback of private health insurance remains-namely, its emphasis on "shallow" coverage. Insurance has concentrated on paying for short hospital stays and other modest bills while insufficiently protecting against large medical expenses, which, being both less predictable and more burdensome when they occur, would seem to be more appropriate for insurance coverage. ${ }^{11}$ The recent trend toward more comprehensive "major medical" insurance, first introduced on a large scale in the early 1950 s and extending in some form to fully 130 million people in $1974,{ }^{12}$

8. The precise relationship between increasing prices and the actual demand for medical insurance is still the subject of empirical debate. See Newhouse, Inflation and Health Insurance, in Health: A Victim or Cause of Inflation? 210, 212-13 (M. Zubkoff ed. 1976).

9. See B. Mitchell \& R. Vogel, Health and Taxes (Rand Report No. R-1222-OEO, Aug. 1973), partially reprinted in 41 So. Economic J. 660 (1975); see also K. Davis, National Health Insurance 14-17 (1975); Feldstein, The Medical Economy, Scientific American 1973, at 151.

10. Mueller \& Piro, Private Health Insurance in 1974: A Review of Coverage Enrollment, and Financial Experience, Soc. Security Bull., Mar. 1976, at 3. See also Health Insurance Institute, Source Book of Health Data 1975-76, at 21-28. Though still substantial, coverage was less for various types of outpatient care. In all, consumers pay out of pocket only about one third of personal health care expenditures. Mueller \& Gibson, National Health Expenditures, Fiscal Year 1975, Soc. Security Bull., Feb. 1976, at 3, 14. The private health insurance industry has experienced very rapid growth as, encouraged by the tax laws, such insurance has become a major fringe benefit for working Americans. See sources cited note 9 supra. Moreover, provider interests-reflected in Blue Cross and Blue Shield plans-have also encouraged coverage as a means of improving patients' ability to pay for services received. See S. Law, Blue Cross: What Went Wrong? 6-12 (2d ed. 1976); Kessel, Price Discrimination in Medicine, 1 J. Law \& Econ. 20, 32-33 (1958).

11. Normally, one would expect people to seek to pool mainly the larger risks through "deep" insurance, covering smaller bills out of pocket to avoid the high administrative and other costs of insuring them. However, because tax subsidies make insurance seem such a bargain (more than compensating for administrative costs, K. DAvis, supra note 9, at 16), various interests can more easily indulge their preference for "first dollar" coverage of routine expenses. Insureds may opt for shallow coverage because they wish to use insurance premiums as easy and convenient forced savings budgeted for health care, e.g., V. Fuchs, WHO Shall Live? 135 (1974), but see Blumstein \& Zubkoff, Perspectives on Government Policy in the Health Sector, 51 Milbank Mem. Fund Q.: Health \& Soc'y 395, 410-11 (1973), or because they underrate the probability of serious illness or accident, or because they rely on government or charity to provide for them in such cases. Both employers and the unions with which they bargain over the provision of much insurance may prefer to benefit everyone with high-visibility shallow coverage rather than deep coverage of direct benefit to only a few. Finally, medical providers clearly prefer insurance that pays the first dollar (or nearly so) of their bills, simplifying their collection problems and reducing consumer cost consciousness. And the private health insurance market has long been dominated by Blue Cross and Blue Shield plans, originated by providers and operated largely in their interest. See generally S. LAw, supra note 10.

12. Mueller \& Piro, supra note 10, at 10, Table 8. See also Health Insurance Institute, 1975-76, supra note 10, at 12, 24-28. 
has reduced the shallowness of coverage somewhat; but, despite its name, a major medical policy does not necessarily provide complete catastrophic coverage. Beneficiaries share costs through deductibles, coinsurance, and "internal limits" on subcategories of expenses; ${ }^{13}$ and coverage may often be restricted or terminated under certain conditions. Moreover, although benefit maximums have grown and now range as high as $\$ 250$ thousand or $\$ 1$ million, with a few plans providing unlimited coverage, ${ }^{14}$ many major medical insureds may still face high medical care costs from expenses above low overall policy limits. ${ }^{15}$

The final recourse of uninsured or underinsured private patients can be described as charity, although providers often benefit from treating "charity patients" in teaching or experimental contexts. ${ }^{16}$ Individual physicians, hospitals, and medical centers have traditionally dispensed a great deal of charitable care, relying on other patients to pay substantially more than the cost of service, on complaisant third-party payers to support such services through bad-debt allowances or otherwise, and on such sources as research and other grants, local government, or private philanthropy to help fund institutional deficits. This unrationalized "system" undoubtedly continues to meet many important health needs, though others may be neglected for lack of a provider with the requisite resources and willingness to accept the financial burden. In particular, the ability of hospitals to act as "monopolistic charities" has been substantially eroded by higher costs and a range of developments limiting internal cross-subsidization. ${ }^{17}$ Nonetheless, there are probably many com-

13. "Internal limits" are coverage maximums for defined subgroups of expenses; certain benefits (for example, mental health care coverage) may thus be exhausted even before the overall coverage limit is reached.

14. Health Insurance Institute, Source Book of Health Insurance Data 1974-75, at 10-11. This deeper coverage is a significant improvement over early limits of $\$ 5,000$ to $\$ 10,000$ designed to provide improved shallow coverage by supplementing basic hospital-surgical insurance. Id. Nonetheless, by 1973 over half of all Americans under age sixty-five did not have even "near catastrophic" coverage $(\$ 25,000$ or more lifetime benefits). 1 A.D. Little, Inc., Financing of Catastrophically Expensive Health Care at 33 (Rep. No. NCHSR-75/104 to DHEW, HRA, Nat'l Ctr. for Health Services Research, Jan. 1975). 36.7 million persons are estimated to have major medical limits of $\$ 250,000$ or above in fiscal 1978. CBO Issue Paper, supra note 2, at 19.

15. See generally Hallman, True Catastrophe Medical Expense Insurance, 39 J. Risk \& Ixs., Mar. 1972 , at 1 .

16. Kessel, The A.M.A. and the Supply of Physicians, 35 Law \& Contemp. Prob. 267, 273 (1970).

17. Potentially one of the most significant of these developments is the National Health Planning and Resources Development Act of 1974, Pub. L. No. 93-641, 88 Stat. 2225 [codified at 42 U.S.C. $\$ 300$ (Supp. IV 1974)]. It requires the Department of Health, Education, and Welfare to develop a uniform institutional rate system reflecting the true cost of providing each type of insured service: "[R]evenues derived from patients in one category shall not be used to support the provision of services to patients in any other category." 42 U.S.C. $\$ 300 n-2(d)(3)(b)$ (Supp. IV 1974). This could substantially alter the currently widespread practice of internal crosssubsidization. See generally Newhouse \& Acton, Compulsory Health Planning Laws and National Health Insurance, in Regulating Health Facilities Construction 217, 228-30 (C. Havighurst ed. 1974); Havighurst, Regulation of Health Facilities and Services by "Certificate of Need," 59 VA. L. Rev. 1143, 1 164-65, 1188-94 (1973); Posner, Taxation by Regulation, 2 Bell J. Econ. \& Mgt. Sc1. 22 (1971). 
munities where uninsured residents still have reasonable expectations of being privately cared for in cases of medical emergency or catastrophically high cost, and reliance on this support may in turn lead some people not to insure against catastrophic risks. ${ }^{18}$

\section{B. Government Programs}

Government is already heavily involved in financing health care, with public programs of various types contributing more than private insurers to total outlays. In fiscal 1975, government spending (two thirds federal, one third state and local) totaled over $\$ 45$ billion and covered about forty percent of total personal health care expenditures. ${ }^{19}$ Although some programs-such as the Veterans Administration, public hospitals, public health activities, and numerous other special programs-provide care directly to recipients, the major governmental role is that of a third-party payer for health care services rendered by private sector providers. The most important such programs are, of course, Medicare and Medicaid, which account for sixty percent of all government health spending. ${ }^{20}$ The federal tax system, by allowing deductions for medical expenses in excess of three percent of adjusted gross income, ${ }^{21}$ also provides a kind of catastrophic health insurance-with a high coinsurance rate inversely related to income. ${ }^{22} \mathrm{~A}$ variety of government programs has also addressed the problem of income lost by sick or disabled people. ${ }^{23}$

Most Americans sixty-five or over are covered by Medicare, as are Social Security disability beneficiaries-those disabled for twenty-four months or having end-stage kidney disease. ${ }^{24}$ Hospital insurance is automatically available under Part A, and voluntary supplementary medical insurance may be

18. See note 38 and accompanying text infra.

19. Mueller \& Gibson, supra note 10 , at 6 , table $1 ; 8$, table 3 ; \& table 5 .

20. See generally id. at 6-11.

21. InT. Rev. CODE of $1954 \S 213$ (a)(1). See also sources cited note 9 supra. The deductibility of medical expenses is estimated to cost $\$ 2.3$ billion in lost tax revenues for fiscal 1978. CBO Issue Paper, supra note 2, at 27.

22. See geneally Mitchell \& Vogel, supra note 9. The "coinsurance rate" is the portion of medical expenses borne by taxpayers, rather than by the government "insurer." Because the federal tax scale is progressive and medical deductions reduce the last dollars of income, upper-income taxpayers pay the lowest coinsurance rate.

23. The federal government provides, mandates, or otherwise encourages income support payments to categorically defined groups of eligible citizens through such programs as Social Security, 42 U.S.C. $\$ 401$ et seq. (1970) (old age, survivors, and disability) and 42 U.S.C. $\$ 1381$ et seq. (Supp. IV 1974) (supplemental security income for the aged, blind, and disabled); public assistance, 42 U.S.C. $\$ 601 \mathrm{et} \mathrm{seq.} \mathrm{(1970)} \mathrm{(aid} \mathrm{to} \mathrm{families} \mathrm{with} \mathrm{dependent} \mathrm{children)} \mathrm{and} 42$ U.S.C. $\$ 1201 \mathrm{et} \mathrm{seq.} \mathrm{(Supp.} \mathrm{IV} \mathrm{1974)} \mathrm{(blind);} \mathrm{Workmen's} \mathrm{Compensation,} 5$ U.S.C. $\$ 8101$ et seq. (1970) (federal employees) and 45 U.S.C. $\$ 51$ et seq. (1970) (railroad employees); unemployment compensation, 5 U.S.C. $\$ 8501$ et seq. (1970) (federal) and 42 U.S.C. $\$ 501$ et seq. (1970) (state); and black lung disability, 30 U.S.C. $\$ 901 \mathrm{et} \mathrm{seq.} \mathrm{(1970).}$

24. 42 U.S.C. $\S 1395$ et seq. (1970); 42 U.S.C. $\$ 426$ (Supp. IV 1974). On Medicare coverage, see generally 1 Medicare \& Medicaid Guide (CCH) I 1000 et seq. (1976). On the kidney provisions, see generally Rettig, supra note 2. 
purchased at a subsidized rate under Part B. Like the Blue Cross and Blue Shield plans after which it is patterned, Medicare emphasizes shallow coverage, though it provides for more hospitalization than do many private plans. Hospital days are limited to 150 , skilled nursing facility days and home health care visits to $100 .{ }^{25}$ Medicare also requires considerable cost sharing, particularly under Part B.

Medicaid covers categorically defined groups of needy persons-the aged, blind, disabled, and families with dependent children. ${ }^{26}$ The program varies considerably among states under the joint federal-state arrangement, but all states must cover people receiving welfare aid under the Social Security Act (the categorically needy), and about half have exercised their option to cover similar persons with income somewhat above welfare levels (the medically needy) as well. ${ }^{2-}$ Required benefits include hospital and physician services, skilled nursing facility care, and lab and X-ray fees; dental and many other health care services are optional. There are no patient cost-sharing requirements for the categorically needy, but states may place limits on coverage even of basic services. ${ }^{28}$

Neither Medicare nor Medicaid fully protects beneficiaries against catastrophic medical expenses. (Moreover, since Medicaid is a categorical program, many low-income people are ineligible for benefits. ${ }^{29}$ ) Under either program, a victim of catastrophic illness may exhaust his coverage and be left to rely upon personal resources and providers' charity. Coverage for hospital

25. Under Part A, home health visits are covered only after a hospital stay of at least three dar's duration. One hundred home health visits are also reimbursable under Part B, without a hospitalization prerequisite, but subject to the coinsurance provisions. 42 U.S.C. $\$ \$ 1395 d, 1395 k$, $1.395 \times(\mathrm{n})(1970)$.

26. 42 U.S.C. $\$ 1396$ et seq. (1970). On Medicaid coverage, see generally 2 MediCARE \& Medicaid Guide (CCH) $\uparrow 14,000$ et seq. (1976).

27. In addition, a complicated "spend down" provision helps protect victims of large medical bills in states covering the medically needy. Persons otherwise eligible for Medicaid but for having an income above welfare levels may nonetheless receive benefits after they "spend down" to the requisite level in paying for health care. 45 C.F.R. $\$ \S 248.1(\mathrm{~b})(2)(\mathrm{iii}), 248.3(1)(\mathrm{ii})(\mathrm{C}) ; 2$ MEDICARE \& Medicaid Guide (CCH) f 14.311 .73 (1976): Urban Systems Research \& Enginecring, Evaluation of Medical Spend-down (DHEW Contrace No. SRS 74-58). For a short and lucid explanation. see R. Stevens \& R. Stevens. Welfare Medicine In America 63-65 (1974). For those eligible, this is a form of catastrophic coverage with a deductible equal to the amount by which their income exceeds the Medicaid level. New York's Medicaid program provides catastrophic coverage for all inpatient expenses exceeding twenty-five per cent of the eligible beneficiary's annual net income where this figure is lower than the "spend down" otherwise required. N.Y. Social SERVICE LAW \& 366(2)(c) (McKinney 1976).

28. Although states may limit coverage they "may not arbitrarily deny or reduce the amount, duration, or scope of, such services... solely because of the diagnosis, type of illness or condition." 45 C.F.R. $\$ 249.10($ a)(5)(i) (1976), 3 Medicare \& Medicaid Guide (CCH) I 21,610 (1976). This would seem to indicate resistance to the disease-oriented approach to containing costs discussed in note 2 supra and in section V.B. infra.

29. Over 6 million people below the poverty line are not covered by Medicaid. K. Davis, supro note 9 , at 2. $43-44$. 
days under Medicaid, for example, is determined by the individual states and may be as little as fifteen days per year. ${ }^{30}$

\section{II}

\section{Proposals for Expanded Coverage}

Although most Americans thus have some form of public or private protection against health care costs, only a minority are well protected against the financial catastrophe which might occur. The inadequacy is clear enough to have caused public concern and new proposals to address the problem. There is reason to expect some form of mandatory coverage encompassing catastrophic illness to be enacted in the next few years. ${ }^{31}$ The design of any plan must take into account the powerful pull of the myth that life is beyond price and must seek institutional structures which will effectively neutralize the myth if optimal resource allocation is to be achieved.

Before analyzing specific proposals, it is useful to consider the rationale for an expanded governmental role in protecting against catastrophic medical costs.

\section{A. A Role for Government}

Viewing catastrophic illness as an independent policy problem calling for independent financing appears to presuppose that government's obligation to assure the provision of medical services is not unlimited. For this reason, proponents of a national cradle-to-grave health care system, typically regarding all health care as a "right"32 (or at least a "merit good"33), would not regard particular illnesses or particular levels of expenditure as a separate problem. ${ }^{34}$ In their view, equity requires a redistributive allocation of in-

30. 2 Medicare \& Medicaid Guide (CCH) ๆ 15,592 (1976). There is of course great disparity among the states; Massachusetts, for example, offers virtually unlimited hospital days. Id. at I 15,598

31. Catastrophic coverage may be provided either as the upper end of a fully comprehensive system or as a free-standing, independently financed program. See section II.B infra. Although the policy justifications for the two approaches are quite different, see section II.A infra, the implications for social involvement in decisions involving human life and health and the problems of correctly allocating resources at the highest level of expenditure are not dissimilar.

32. See e.g., Institute of Medicine, National Academy of Sciences, Implications of Guaranteeing Medical Care. (J. Perpich ed. 1975).

33. A "merit" good is one whose governmental provision or funding is justified by explicit political choice, not by traditional public finance criteria (e.g., externality, public good, monopoly, or market imperfection). Its provision reflects a communal, paternalistic judgment about what people should consume, regardless of their actual consumption decisions, and is thus similar to, but distinct from, concern for equitable distribution of resources. See Blumstein \& Zubkoff, supra note 11, at 400-12; see also Fein, On Achieving Access and Equity in Health Care, in Economic Aspects of Health Care 23 (J. McKinlay ed. 1973); Musgrave, Provision for Social Goods in the Market System, 26 Pub. Finance 304, 312-13 (1971).

34. For example, one comprehensive system (West Germany's) apparently does not even keep data that distinguish catastrophically expensive from other health expenditures. Interview with $U$. 
kind medical benefits across the board to assure equal access to all types of health care, whatever the health problem. Focusing on catastrophic care may be seen as betraying a fundamental tenet, unacceptably providing only half a loaf. ${ }^{35}$

In the absence of philosophical or political consensus in favor of a universal comprehensive government role, however, a catastrophic coverage approach might well seem justified by the perception that the current lack of protection against extremely high costs is a deficiency in current health care financing that warrants governmental redress. Such a plan may have widespread political appeal, since it protects middle-class families against financial hardship or disaster while assuring poorer families of the means of paying for treatment which they otherwise might not get at all. ${ }^{36}$ This approach also comports with the view that government intervention should proceed only incrementally, with each increment justified separately and each program tailored to fit the articulated rationale. ${ }^{37}$

Given a widespread acceptance of some governmental role in financing catastrophic health care, the nature of that role remains to be considered. Market-oriented advocates of limited government involvement might argue that catastrophically expensive illness is an insurable risk most efficiently dealt with in a private insurance market. Government, in this view, should intervene as necessary to improve the functioning of the market so as to allow those who wished catastrophic protection to buy it, but not to impose coverage on those who prefer to bear risks on their own. Equity concerns could be met by income supplements rather than by in-kind benefits, so that even the poor could make a free choice between risk-taking and insurance.

But such a limited role for government does not take into account the larger burden which society frequently assumes voluntarily when an individual is afflicted with a medical catastrophe. Through a variety of charitable acts and public agencies, as a society we do often act to help those who have not helped themselves. Knowing this, many individuals might not buy insurance, however readily available and fairly priced, because they know that

Geissler, Ministry of Labor \& Social Affairs, in Bonn, West Germany, June 1975.

35. Others who favor comprehensive national health insurance nonetheless support catastrophic-only coverage on the theory that half a loaf is better than none, at least as a first step toward a more inclusive program. This stance reflects both a political judgment that a comprehensive program is not fiscally feasible at present and a willingness to compromise by accepting one piece of the larger package they seek. See generally Meyer, The National Health Insurance Debate: Shifts Toulurds Reality? I J. Health Politics, Policy \& Law 13 (1976).

36. Catastrophic illness also typically causes considerable functional dislocation-inability to perform normal work or family roles. Many see this as a serious social disruption, warranting governmental action. See generally Blumstein \& Zubkoff, supra note 11, at 399, 423-25.

37. See Blumstein \& Zubkoff, Public Choice in Health: Problems, Politics and Perspectives On Formulating National Health Policy, Inr'l J. of Health Services (forthcoming); Blumstein \& Zubkoff, supra note 11 , at 395-96, 400-01, 418, 426. See also note 35 supra. 
some protection already exists in the willingness of others to come to their aid in an emergency. ${ }^{38}$ For persons having other uses for the cash, forgoing insurance might be quite rational, and mandating contributions by all may be the only way of preventing such "free riders" from taking advantage of society's good nature in this way. Moreover, regularizing financial support for such services better distributes these social costs, relieving particular providers, notably community hospitals, of their disproportionate financial burdens and of the even greater burden of turning away needy patients when the available resources are insufficient.

Individual decisions to self-insure have other types of social consequences as well, such as the "impact of a mistaken choice by a head of a household ... on others who are dependent"; ${ }^{39}$ society may well question whether that determination should be left solely in private hands. These externalities are especially significant for children, who do not have independent funds or sufficient information or experience to make an informed private choice. Moreover, the state has accepted a special responsibility for the welfare of children and will have to care for them if their parents are incapacitated or if their health needs are neglected by their parents. Given its own direct interest, the government might appropriately require some individual contribution toward catastrophic coverage. ${ }^{40}$

Although the theoretical underpinnings of a government catastrophic disease program are strong, there remain many practical questions of its design and potential cost.

\section{B. Current Proposals}

Almost all national health insurance proposals provide some form of coverage for catastrophic medical expense. A number of proposals, including the Kennedy-Corman Health Security Act, would not treat catastrophic expense as a separate category, but would instead cover it together with ordinary expenses under a unified plan with very extensive benefits. ${ }^{41}$ In contrast,

\footnotetext{
38. See Blumstein \& Zubkoff, supra note 11, at 421-25.

39. Id. at 423-24.

40. Id. See also V. Fuchs, supra note 11, at 133, 150 (compulsory coverage grounded in concern over "free riders" and children).

41. S. 3 \& H.R. 21, 94th Cong.. Ist Sess. (1975) in Hearings on National Health Insurance Major Proposals Before the Subcomm. on Health E the Entironment of the House Comm. on Interstate 8 Foreign Commerce, 94th Cong., Ist Sess. 475 (1975) [hereinafter cited as 1975 Hearings]. The former Nixon Administration plan, S. 2970 \& H.R. 12684, 93d Cong., 2d Sess. (1974) in 1 Hearings on National Health Insurance Before the House Comm. on Ways E Means, 93d Cong., 2d Sess. 262 (1974) [hereinafter cited as 1974 Hearings], and others are likewise comprehensive plans. Broad comparisons among bills are more easily made from summary treatments of insurance proposals than from the actual bills. See, e.g., K. Davis, supra note 9, at 80-128; OfFice of Research \& Statistics, Soc. Security Admin., U.S. Dep't of Health, Educ. \& Welfare, National Health Insurance Proposals (DHEW Pub. No. (SSA) 76-11920, 1976) [hereinafter cited as DHEW Summary]; Staff of Senate Comm. on Finance, 93d Cong., 2d Sess., National Health Insurance: Brief Outline of Pending Bills (Comm. Print 1974).
} 
several other plans now under active consideration address catastrophic expenses as a separate category, though they may also envision additional basic health insurance underlying the proposed catastrophic coverage. ${ }^{\mathbf{4 2}}$

Such proposals are quite complex and may profitably be analyzed from many points of view. This article is primarily concerned with the boundaries of any undertaking to meet catastrophic medical expenses. From this perspective two attributes of the proposals are salient-whether and how they establish lower and upper bounds to the financing commitment and what expenses or types of care (if any) are excluded from full coverage.

A proposal's deductible feature (for catastrophic-only plans, the coverage threshold) affects its total program cost, but does not directly limit total expenditures on the treatment of catastrophic disease. That function may be performed by upper limits of various sorts, by cost-sharing requirements, or by exclusions from coverage. Most plans would establish no total exclusions of care from catastrophic coverage, ${ }^{43}$ but internal limits on particular services are not uncommon. ${ }^{44}$ Many proposals include cost sharing for particular benefits, either as coinsurance percentages or as fixed deductible or copayment amounts, but cost-sharing requirements are typically eliminated entirely in catastrophic ranges. ${ }^{45}$

42. The Long-Ribicoff proposal, the leading catastrophic-only plan, would assure the availability of basic health insurance meeting minimum federal criteria. S. 2470, 94th Cong., 1st Sess., Title III (1975). Professor Feldstein's Major Risk Insurance (MRI) proposal, on the other hand, was designed in part to induce patient self-insurance below the sizeable deductible. Feldstein, A New Approach to National Health Insurance, 23 PUB. Interest 93 (Spr. 1971). The basic MRI goal was to limit family liability for medical expenses to a reasonable proportion of income, yet to maintain cost consciousness below that level. Given unlimited MRI coverage above a family's limit, families should not find it attractive to insure expenses below the MRI threshold, since coverage would cost almost as much as their maximum liability under MRI (and more than their expected average liability). $I d$. at 100 . Coinsurance above a basic deductible was proposed to increase the range of expenses for which a family would have some responsibility. Id. at 103-04.

Professor Feldstein has recently up-dated his analysis and re-emphasized the virtues of MRI. Address by Martin Feldstein, Carl Snyder Memorial Lecture, Univ. of Cal. at Santa Barbara, (Jan. 18, 1977). Patient responsibility for ordinary rather than catastrophic expenditures is still emphasized, but coinsurance would apply beginning with the first dollar of expenses rather than only above a deductible. $I d$. at $\mathbf{2 8}$.

43. It is not uncommon, however, for plans to exclude some relatively low-expense but highfrequency categories, such as outpatient drugs or eveglasses. E.g., H.R. 1. 94th Cong., Ist Sess. (1975) in 1975 Hearings, supra note 41 , at 302 (eyeglasses excluded for those aged thirteen and over).

44. These limit coverage of one kind without affecting maximum benefits for all care or treatment. Sep note 13 supra. Thus, the Long-Ribicoff bill would limit psychiatric hospital inpatient treatment to one hundred and ninety lifetime days and set a maximum of two hundred and fifty dollars payable for outpatient mental health care. S. 2470, 94th Cong. Ist Sess. (1975). The 1974 Nixon Administration plan would have limited skilled nursing facility days to one hundred per year. S. 2970 \& H.R. 12684. 93d Cong., 2d Sess. (1974) in 1974 Hearings, supra note 41, at 262.

45. For example, the 1974 Kennedy-Mills proposal, H.R. 13870 \& S. 3286, 93d Cong., 2d Sess. (1974) in 1974 Hearings, supra note 41, at 4, called for twenty-five per cent coinsurance, but limited yearly cost sharing to a maximum of one thousand dollars per family. Similarly, under 
Almost all federal bills to cover catastrophic medical expenses have theoretically unlimited overall benefits. ${ }^{46}$ This does not, however, constitute an unbounded financial commitment; it does mean that other cost-control mechanisms must be looked to. Cost sharing and internal limits have already been mentioned. A number of plans call for Professional Standards Review Organization (PSRO) or other review, which would set some individual limits (on days of hospitalization, redundant diagnostic tests, and so forth) independent of listed program benefits. ${ }^{47}$ Moreover, the Health Security proposal, though it would not directly limit benefits to any individual, does contemplate fixed, advance payments to designated health service areas, in which administrative processes would in turn have to limit overall payments to providers. ${ }^{48}$ Provision for care rendered by health maintenance organizations, a feature of several plans, would have a similar effect. ${ }^{49}$

Some proposals do set ceilings on total dollar expenditures per beneficiary per specified time period, such as spell of illness, year, or lifetime. The Nixon Administration's early proposal for a National Health Insurance Partnership Act, for example, would have imposed such a limit on supplemental catastrophic payments (above broad basic benefits). ${ }^{50}$

Interestingly, benefit limitations are seldom related to specific policy goals (other than the obvious cost savings). No distinction is made, for example, among types of care according to any social valuation of the lives threatened or saved or according to any estimate of the value of treating particular illnesses or of adopting particular modes of treatment. ${ }^{51}$ Although Congress

the Long-Ribicoff bill, patients would face no coinsurance payments after meeting the deductible amounts. S. 2470, 94th Cong.. Ist Sess. (1975).

46. For example, neither the Health Security proposal, S. 3 \& H.R. 21, 94th Cong.. Ist Sess. (1975) in 1975 Hearings, supre note 41, at 475 (a comprehensive plan). nor the Long-Ribicoff bill, S. 2470, 94th Cong.. Ist Sess. (1975) (catastrophic only) would place at ceiling on total expenditures in catastrophic ranges on behalf of an individual insured: in particular, hospital and physician services are fully covered.

47. See section III.B.2. and note $11.4 \mathrm{infra}$.

48. S. 3 \& H.R. 21, 94th Cong., Ist Sess. $\$ \$ 61-90(1975)$ in 1975 Herings, supra note 41, at 475. See also Section IV.C. infra.

49. Id. at $\S 87 ;$ H.R. 2049 \& 2050, 94th Cong. Ist Sess. (1975) (Rep. Staggers-10 per cent premium subsidy). See also section III.B.3. infra.

50. S. 1623 \& H.R. 7741, 92d Cong., 2d Sess. (1972). H.R. 2618, 93d Cong., 1st Sess. (1973) (Rep. Railsback) had a similar provision. The lifetime maximum was $\$ 50$ thousand and was to be reduced by the amount of each catastrophic expenditure (i.e., one not covered under the broad basic coverage). But maximum coverage was to be restored at the rate of wo thousand dollars each succeeding year (less any further catastrophic outlays in a given vear). For example. a beneficiary who receives $\$ 20$ thousand under the catastrophic coverage thus reduces to $\$ 30$ thousand the lifetime amount thereafter avalable to him under the catastrophic coverage. The full $\$ 50$ thousand maximum will be restored, however, after ten years without any further catastrophic expenditures. This add-back mechanism is a feature of the Federal Employees Health Benefits Act plans (high option), sometimes suggested as a model for comprehensive national health insurance. See 2 A.D. Little, supra note 14, at 33 .

51. Cf. note 28 supra (no such "arbitrary" distinctions allowed). 
frequently makes such judgments, at least implicitly, in establishing priorities for biomedical research and in defining eligibility for income support programs, policymakers apparently feel that treatment priorities should be determined by some other means. Although the commonly found restriction on mental health services may reflect an exception to this generalization, it can also be seen as a defense against the very high costs possible as a result of the high degree of patient discretion about the consumption of such services. The only catastrophic insurance "plan" seeming to embody a judgment about the worth of specific care is the current end-stage renal disease program under Medicare, and this start toward a "disease-by-disease" approach to catastrophic coverage has been much criticized..$^{2}$

\section{Predicting Potential Costs}

The current incidence of catastrophic illness and its costs, however defined, are poorly understood. The expected experience under some form of national program covering high expenses is therefore difficult to predict. Different methods of extrapolating from present knowledge yield varying estimates of catastrophic health insurance costs, ranging from very low to extremely high. All methods have deficiencies, perhaps the most important one being the ubiquitous problem of how to assess "induced" costs-those generated by creation of a new financing system.

Consideration of the present costs of treating various diseases and conditions thought to be "catastrophic" yields a rough idea of potential costs, even though current proposals themselves are not condition-specific. An annual $\$ 1$ billion for kidney disease (under current programs alone) is a widely cited figure. ${ }^{53}$ A like amount could easily go for joint replacement surgery. ${ }^{54}$ If all potential beneficiaries were treated, the coronary bypass operation alone could cost some $\$ 20$ billion in the first years of a catastrophic insurance program, and $\$ 2$ to 4 billion per year thereafter. ${ }^{55}$ The average cost of caring for a terminal cancer patient is $\$ 20,000$, according to one source. ${ }^{56}$ The expense

52. See note I supra.

53. InSTITUTE OF Medicine, supra note 1, at 1; see also ESRD: A Billion a Year for Direct Kidney Care, Med. World News, May 3. 1974, at 16: Iglehart, Kidney Treatment Problem Readies HEW for National Health Insurance. 8 NAT'L J. 895 (1976). Some sources foresee an ultimate annual cost of $\$ 2$ billion. Long-Term Dialysis Programs: Neu Selection Criteria, Neu Problems, Hastings Ctr. ReP., June 1976, at 8,11 .

54. Nat'l Center for Health Services Research Health Resources Admin., Public Health Service, U.S. Dep't of Health, Educ. \& Welfare. Report, Catastrophic lliness Conference, Dec. 1-3, 1974, at 12 (DHEW Pub. No. HRA 76-3133 1974).

55. McClure, The Medical Care System under National Health Insurance: Four Models. 1 J. HEALTH Politics, Policy \& Law 22, 24 (1976).

56. K. Davis, supra note 9, at 4. Terminally ill long-term alcoholics may also receive very extensive care. Those with bleeding esophageal varices can be kept from bleeding to death by many transfusions and two operations, although they usually die from kidney failure soon thereafter. "The cost per case may approach $\$ 20,000$ and the cost per year of life saved may approach a million dollars." Neuhauser, The REALLY Effective Health Service Delivery System, HeALTH CARE MANAGEMENT ReVIEW, Winter 1976, at 25, 27-28. 
of rehabilitating a quadriplegic accident victim is said to average $\$ 12,000$ (with success in one case out of four). ${ }^{57}$ The cost of as yet unavailable therapies, such as bone marrow transplants, cancer treatments and the often-cited artificial heart, ${ }^{58}$ is incalculable. Such a piecemeal recitation of potential expenditures is methodologically unsatisfying but does illustrate the potential of the health care system to absorb resources in vast quantities. ${ }^{59}$

A 1974 study by the Department of Health, Education, and Welfare (DHEW) estimated the costs of eight then-current proposals by adding to present expenditures the increased demand for services brought about by extra insurance coverage. That estimate, for fiscal 1975, was that the catastrophic coverage of the Long-Ribicoff bill would induce expenditures of only $\$ 4.4$ billion, raising the total national health bill only some 3.8 per cent. ${ }^{60} \mathrm{~A}$ major 1975 study by Arthur D. Little, Inc. estimated the cost of providing catastrophic coverage to the entire American population under age sixty-five. The study analyzed the 1970 experience of the Federal Employees Health Benefits Program, which provides very comprehensive coverage. Generalizing from data under an existing catastrophic plan was thought to justify ignoring induced costs on the assumption that demand under the private and any public plan would be very similar. This calculation led to an estimated incremental 1975 cost of only $\$ 1.94$ billion for Senator Long's catastrophic health insurance program. ${ }^{61}$ A 1976 study for DHEW foresaw a rise of $\$ 7.9$ billion by

57. 1974 Hearings, supra note 41, vol. 2, at 925 (statement of W. Spencer). Of course high costs are not unique to diseases or conditions commonly thought catastrophic. Long-term care has already been mentioned. See note 2 supra. Short-term intensive care for a variety of conditions is also very expensive. In one large urban teaching hospital, a recent study of two hundred twenty-six critically ill (primarily postoperative) patients showed an average hosputal charge of $\$ 14.304$, of which only six per cent was paid by patients. Over half died within a month: nearly three-quarters within a year: only one-eighth fully recovered. Cullen. Ferrara, Brigs, Walker \& Gilbert, Survizal, Hospitalization Charges and Follow-Up Results in Critically Ill Patients, 294 New ENG. J. MED. 982, 982, 986 (1976) [hereinafter cited as Cullen, at al.]; accord, Scott, Letter to the Editor, 295 NEW ENG. J. MED. 398 (1976).

58. See Artificial Heart Assessment Panel. supra note 6

59. Walter McClure notes that under a regime of universal and unlimited entitlement, "we run the risk of our medical care system becoming a kind of vast vacuum cleaner. sucking uncontrollable amounts of GNP and scarce tax dollars-urgently needed for other equally pressing national priorities-and putting them to medical care." McClure, supra note 55, at 25.

60. U.S. Dept. of Health. Educ. \& Welfare. Estimated Health Expenditures under Selected National Health Insurance Bills 3, 12 (July 1974). The particular version of the bill used for the estimates evidently was S. 2513.92 d Cong., 1st Sess. (1973), an earlier version of S. 2470 (1975), supra note 42. The figures for the more comprehensive Nixon Administration plan and the Health Security Act were $\$ 6.5$ and $\$ 13$ billion, respectively. $l d$. All figures were projected from fiscal 1973 data, yielding an estimated 1975 total health care expenditure of $\$ 116.4$ billion, of which \$103 billion was for personal health care-exclusive of research, construction, public health, and the like. The actual 1975 figures turned out to be $\$ 118.5$ and 103.2 billion, respectively. Mueller \& Gibson, supra note 10 , at 3, 14.

61. 1 A.D. Little, supra note 14, at 163. The bill evaluated was Senator Longs S. 1416, 92d Cong., Ist Sess. (1973). See also notes 14, 60 supra. The data and research design of the A.D. Little study have, however, been severely criticized. The Director of the National Center for Health Services Research, for which the study was done, inserted an introductory memorandum 
1980 under catastrophic coverage. ${ }^{62}$ Although such estimates indicate that a catastrophic health insurance plan might be instituted at a relatively small initial cost, a circumstance in no small measure responsible for the political appeal of catastrophic plans, the most difficult aspects of projecting costs are not satisfactorily dealt with by existing estimates.

Direct extrapolation from current insurance experience does not fully account for the impact of universal coverage with virtually no upper limits because emphasis on deep coverage could considerably alter medical care delivery as it now exists. Not only might cost inflation result from the infusion of virtually unlimited new financing into highly specialized institutional care, but inflationary pressure might extend to noncovered care as well, to the extent that there is added competition for scarce medical resources in the short run. Moreover, any program insuring upper-level expenditures may create a spectacular incentive for providers to offer the highest possible quality regardless of cost all along the line in the expectation that insurance would take over just as the patient begins to feel the pinch. In the long run, catastrophic-only coverage might skew resource allocation toward institutional care and away from outpatient care, home health care, and health maintenance, just at a time when the system's bias toward hospital-based acute care and its traditional failure to provide primary and preventive care are widely deplored. ${ }^{63}$ Expenditure increases of some magnitude could also be expected because improved catastrophic care will save some people who would otherwise have perished and who then must be maintained in a subnormal state at great cost. Although the value of cures achieved and lives prolonged should be recognized, expensive medical intervention may in some cases be more accurately seen as postponing death than as prolonging life.

The most significant and least predictable variable, however, is the change in medical practice or technology that might be induced by extensive catastrophic coverage. If a new program simply altered financing arrangements,

into the final report cautioning readers of its limitations, notably "that the cost estimates are inherently downward-biased." Id. at i-A.

Another study, Newhouse. Phelps \&. Schwartz. Policy Options and the Impact of National Health Insurance. 290 NEw ENG. J. MED. 1345 (1974), while giving no long-term dollar estimates. concluded that fully comprehensive coverage would cause only a small increase (about five to fifteen per cent) in demand for inpatient services (likely to compose the bulk of catastrophic expenditures). Id. at 1346 .

62. Total national health care expenditures of $\$ 233.3$ billion were projected for 1980 under the Long-Ribicoff bill, compared with $\$ 223.5$ billion under present law. Gordon R. Trapnel. Associates, a Comparison of the Costs of Major National Health insurance Proposals, Executive Summary (DHEW Rep't No. PB-259-153. Oct. 1976). The Congressional Budget Office has estimated the new costs generated by a variety of hypothetical catastrophic plans; they range from only $\$ 0.4$ billion to $\$ 16.0$ billion for fiscal 1978. CBO Issue Paper, supra note 2, at 38 . 42.

63. Sep, e.g. Somers, Catastrophic Health Insurance? A Catastrophe! Medical. Economics, May 10 , 1971. at 213 . 
one might expect the increase in aggregate costs to be manageable, since there are comparatively few catastrophes involved. But it is not reasonable to expect doctors' and patients' definition of a medical catastrophe to remain unchanged. Just as shallow hospital "insurance coverage has unnecessarily shifted many vertical ambulatory-care patients into the more expensive horizontal treatment in the hospital bed," deep insurance for large expenditures only may create "a raging epidemic of bigger and better medical catastrophes with a sharp increase in cost." 64 Moreover, the deep governmental or insurer pocket under any form of catastrophic illness program, by removing the financial constraint on demand, would stimulate heavy private investment in research to develop new forms of lifesaving and health-promoting technology. ${ }^{65}$ Not all new developments would generate benefits commensurate with their costs, yet, once they existed, their use would be difficult to control. ${ }^{66}$

For a variety of reasons, therefore, predicting the ultimate cost of a catastrophic health insurance plan is even more difficult than predicting first-year

64. Rutstein, Letter to the Editor, 294 NEw ENG. J. MeD. 346 (1976). The author, a doctor at Harvard Medical School, was responding to Harris \& Wissman, Impact of Nationuide Catastrophic Health Insurance, 293 NEw ENG. J. MED. 721 (1975), which summarized the A.D. Little report, supra note 14.

65. If catastrophic care were well financed, government would lose the control it potentially enjoys to influence the course of basic and applied biomedical research through its setting of funding priorities, since guaranteed insurance payments would probably attract sufficient risk capital even without specific grant funds. Such control has not been exercised in the past so as to prevent discoveries whose implementation would be costly and whose benefits would be small. See Gruenberg, The Failure of Success, 55 Milbank Mem. Fund Q: Health \& Soc'y 3 (1977); Inglehart, Is It Time for Biomedical Research to Hunt for New Fields? 8 NaT'L J. 1217 (1976). Recent years, however, have seen a growing interest in controlling medical technology, although technology assessment is a relatively new field, and "biomedical technology has been almost totally ignored." Walters, Technology Assessment and Genetics, 33 Theological Studies 666, 672 \& n.21 (1972). Some specific medical technologies have been scrutinized, e.g., Artificial Heart Assessment PANEL, supra note 6, and calls are beginning to be heard for more general reviews of research and development. See, e.g., C. Taft, P. Gertman, \& R. Egdahl, Health Care Technology (1977); Iglehart, The Cost and Regulation of Medical Technology: Future Policy Directions, 55 Milbank Mem. Fund Q.: Health \& Soc'y 25 (1977); Gaus, What Goes into Technology Must Come Out in Costs in National Leadership Conference on Americas Health Policy 12 (1976); Hiatt, Too Much Medical Technology? Wall St. J., June 24, 1976, at 16, col. 4; Schwartz, On Medical Progress, N.Y. Times, April 13. 1976, at 33, col. 5; Ebert. The New Technology-How Far, How Fast? Am. Med. New's/Impact, June 28, 1976, at 2, col. 1.

66. The major theme of this article is the difficulty of limiting low-value catastrophic spending, given the natural impulse to do everything possible for identified patients whose lives are endangered. Once a treatment is past the experimental stage, suppressing its application as too costly is extraordinarily difficult. See also notes 63 supra and 111 infra.

Of course, the prevalence of expensive therapies and maintenance is in itself an incentive for basic research on cures or prevention, as in the classic case of polio vaccine's supplanting very expensive iron-lung treatment. See Rettig, supra note 1 , at 211 \& $\mathrm{n} .48$. The iron lung is a "halfway technology," an expensive treatment of symptoms after the fact, whereas the vaccine is an example of "full technology," a comparatively simple measure born of "genuine understanding of disease mechanisms. "Thomas, Guessing and Knowing: Reflections on the Science and Technology of Medicine, Saturday Review 54, (Jan. 1973), discussed in Rettig, supra note 1, at 209. 
costs. It does seem appropriate to worry that unlimited financing of expensive hospital-based care could easily yield powerful inflationary effects, much as hospital costs have risen in the past in response to increasing insurance coverage ${ }^{67}$ There is some evidence that medical costs are already rising faster in catastrophic ranges than in general. ${ }^{68}$ Without some constraint, chronic pressure for cost escalation would continue and could even increase, with no equilibrium in sight, because of the capacity of technology to expand almost indefinitely to meet virtually unconstrained demand. ${ }^{69}$

\section{III}

\section{The Problem of Controlling Costs in a Catastrophic Disease Program}

Although expanding government's role in financing catastrophic care could be very expensive, high costs alone would not be objectionable if there were some assurance that particular expenditures would yield roughly commensurate benefits. ${ }^{70}$ Even without an expectation that a new program would routinely make such sophisticated evaluations of individual services, it could be considered worthwhile if its benefits outweighed its costs in the aggregate and if no practical alternative offered better control of marginal expenditures. ${ }^{71}$ It would be wrong, however, to maintain that any prospect (no matter

67. See generally M. Feldstein, The Rising Cost of Hospital Care (1971).

68. People with catastrophic expenses claim a very large and growing share of all medical spending. In 1970, the top one per cent of the population in amount of medical expenses accounted for fully twenty-six per cent of total medical expenses. (The bottom twenty-five per cent accounted for only one per cent of spending), R. Anderson, J. Lion, \& O. Anderson, Two Decades of Health Services 96. Table 3-11 (1976). For the 1963-70 period, the growth in total medical expenditures for the top one per cent was 17.2 per cent per year, compared with "only" 11.2 per cent for the population at large. Id. at 97. Table 3-12. See also CBO lssue Paper, supra note 2 , at 45-46 (the higher the catastrophic expenditure category, the faster spending increased in 1970-75).

69. The Congressional Budget Office, CBO Issue Paper, supra note 2, at 44 , summarizes:

Fifteen years' experience with private health insurance coverage, medicare, and medicaid suggests that catastrophic health insurance (or comprehensive national health insurance) would stimulate the use of high-cost treatments and the growth of expensive facilities, particularly hospitals. . .

The supply of medical services will probably expand rapidly to meet whatever demand is generated by a new insurance system. Expensive techniques and services will be adopted as rapidly as there are funds to pay for them. . . stantial.

70. This statement is less self-evident than it seems. One person's benefits must typically be weighed against costs to someone else, contrary to the neoclassical economic axiom that interpersonal comparisons of utility are unwarranted. Utilitarian benefit-cost comparisons nonetheless provide a very useful analytical framework and are widely used. The textual statement is, moreover, oversimplified, since many potential government expenditures may have benefits exceeding their costs. Other, possibly more beneficial programs must be considered, and normative questions about who should pay for what and who should receive what must be addressed.

71. The overall program would thus be justified on benefit-cost grounds; and no achievable program change could do better, even though some uncontrollable marginal expenditures would 
how improbable) of prolonging even a few lives is itself a priceless benefit that would justify any expenditure under a catastrophic health care program.

Although our society appropriately values lifesaving very highly, significant questions about the value of catastrophic health care expenditures can arise on at least three levels:

First, doubts can be raised about the effectiveness of, and necessity for, many of the particular medical services which would be subsidized: Not all possible medical services contribute meaningfully or in the same measure to patients' survival. ${ }^{72}$

Second, the value of the benefits derived in individual cases is highly variable: Not all catastrophic disease is actually life-threatening; ${ }^{73}$ not all lives threatened are in fact saved $7^{74}$ and not all prolongations of life achieved are quantitatively or qualitatively alike, since some patients are maintained in states of health which they would not value highly. ${ }^{75}$

Third, once a program has made us feel collectively responsible, we may over-exalt particular lifesaving efforts, almost independently of their benefit to patients, as a way of affirming our society's deeply felt reverence for the sanctity of life. Society obviously cannot indefinitely afford to indulge this propensity - which we label the "lifesaving imperative" ${ }^{6}$ _by applying all available means of modern medical technology to every case, but neither can society afford overtly to breach such a fundamental tenet. As a compassionate society seeking to do the most good with limited resources, we must be especially careful not to create a no-win dilemma where the only apparent alternatives are unlimited spending of questionable effectiveness or overt public sacrifice of human life. The former would surely prove unacceptably expensive, but the latter (which high costs could help to precipitate) would be ethically demoralizing.

not be worthwhile. The benefit-cost ratios of entirely different government programs should not, however, be forgotten.

72. Some expensive treatments may achieve at best only very small reductions in the probability of death or small increases in the likelihood of improved recovery. For example, recent research questions the value of intensive institutional care for heart attack victims. E.g. . Mather, Pearson. Read, Shaw. Steed. Thorne, Jones. Guerrier. Eraut, McHugh, Chowdhury, Jafary, \& Wallace, Acute Mrocardial Infartion: Home and Hospital Treatment, 1971-3 Brit. Med. J. 334. 336-37. Seo also A. Cochrane. Efrectiveness and Efficiency $50-54$ (1972).

73. See note 2 supra.

74. One study found that almost three-quarters of the intensive-care patients treated at great expense survived less than a year, Cullen, et al., supra note 57, at 983. Physicians can and often must make critical distinctions among patients and set treatment priorities. The patients just cited, for example, were chosen to receive the most intensive postoperative care; three other categories of lesser degrees of care were established. Id.

75. Indeed, many patients might be "saved" only to be maintained in states of "health" which they would not value highly. See, e.g., In re Quinlan, 70 N.J. 10, 41, 355 A.2d 647, 664 (1976) (most irreversibly comatose people would, if they could, choose to discontinue life-supporting treatment). $C f$. Gleitman v. Cosgrove, 49 N.J. 22, 227 A.2d 689 (1967) (wrongful life claim).

76. See generally section III.A. infra E passim. 
Avoiding this dilemma is not an easy task; this section of the article details the immense practical difficulty of using regulatory or other decisionmaking mechanisms to contend with the lifesaving imperative, an ethic which colors all attempts at realistic appraisal of risks, benefits, and costs. It is only natural for medical care providers to seek to frame all catastrophic care issues in lifesaving terms. They naturally prefer to take any step that might conceivably promote health or prolong life; indeed they fear legal liability for omitting any particular measure. Likewise, individual patients and their families cannot be expected to deny themselves any catastrophic ministration of potential medical value when it would be financed by others-except in circumstances where more fundamental ethical or religious values take precedence, as may sometimes occur in hopeless or terminal cases. ${ }^{77}$ And serious problems are encountered if some third party, particularly government, must take upon itself the responsibility for a decision setting a low value-or any value, for that matter-on an individual's survival, comfort, or welfare. The social, political, and legal dynamics of controlling catastrophic health care costs in this highly charged context present a major challenge to policymakers intent on achieving efficient and humane catastrophic treatment without offending deeply held values. Meeting the challenge requires considerable attention to the nature of government's role as it is expressed in the institutional structure of any program for softening the blow of catastrophically expensive, debilitating illness.

\section{A. The Lifesaving Imperative}

It is a basic tenet of our society that we will not give up a life to save dollars, even a great many dollars. ${ }^{78}$ This strong belief in the sanctity of life leads us to reject our usual weighing of benefits and costs when human life appears to be in our hands. Thus, whenever government is obviously placed in a position to undertake a specific lifesaving effort, we would all feel collectively responsible for the resulting loss of life if action were not taken. Because of this "lifesaving imperative," government is unlikely to allow an individual in jeopardy to perish for reasons of economy where any expenditure might save him. ${ }^{79}$ We are likely to be similarly uncomfortable if we observe

77. See generally section IV. D. infra.

78. See, e.g., Zeckhauser, Coverage for Catastrophic Illness. 21 Pub. Policr 149 (1973) [hereinafter cited as Zeckhauser, Catastrophic Illness]; Zeckhauser, Procedures for Valuing Lives, 23 Pub. Policy 419 (1975) [hereinafter cited as Zeckhauser, Valuing Lives].

79. In medicine, the lifesaving imperative is strengthened by the professional ethic of physicians that everything possible should be done for their patients-a similar phenomenon elsewhere called the "quality imperative," Havighurst \& Blumstein, supra note 5, at 20-30, or the "technological imperative." V. Fuchs, supra note 11, at 60; Fuchs, The Growing Demand for Medical Care in Essays in the Economics of Health and Medical Care 61, 66 (V. Fuchs ed. 1972). See also Hiatt, Protecting the Medical Commons: Who is Responsible?, 293 New Eng. J. Med. 235 (1975). But see sources cited note 251 infra (when physician may terminate care). 
government making close calculations about whether it is in fact worthwhile to take other, more general measures which might save lives.

We may recognize that the lifesaving imperative is to some extent a myth. While we do occasionally invest great amounts in saving identified lives in jeopardy, we also accept the loss of many "statistical" lives as part of the price of the many benefits of industrial society. ${ }^{80}$ But even if it is in part a myth, belief that life is beyond price is an important feature of our collective existence: Our treating identified victims differently from statistical victims should not be dismissed as a simple case of hypocrisy or as a mistake in valuing lives, ${ }^{81}$ for it is in large part a ritual homage paid to the sanctity of human life and to our collective commitment to maintain it. Policy actions that seemed

80. It has long been recognized that societv's devotion 10 lifesaving is greatest where the threat is to identifiable individuals, like trapped miners-or the victims of catastrophic disease. See. e.g., Fuller, The Case of the Speluncean Explorers, 62 Harv. L. REv, 616. 623 (1949). See also Fried, The Value of Life. 88 Harv. L. Rev. 1415 (1969); Havighurst \& Blumstein, supra note 5, at 21-25; Schelling. The Life You Sane May Be Your Oun. in Problems in Public EXPEnditure Analysis 127 (S. Chase ed. 1968); Zeckhauser, Valuing Lives, supra note 78, at 447, 458-59.

Not only does society spend more in attempting to save identified lives than statistical ones, but it also considers identified death a greater cost. Thus, the FDA has been very restrictive of new drugs-in part because the deaths that may result from allowing a drug to be marketed are clearly visible, whereas those who die because a drug is not available are impossible to identify. See D. Seidman, Protection and Overprotection: The Politics and Economics of Pharmaceutical Regulation 30 (paper presented at the 1976 Anmual Meeting of the Midwest Political Science Ass'n, April 29-May 1, 1976). Indeed. the highly personalized and visible horrors of thalidomide-averted in the United States by FDA caution-are often cited as strong support for continuing the current policy of stringent FDA review.

81. The "myth" is casily described, but the riddle of how a society might rationally choose to spend more to save identified than statistical lives has been addressed only inconclusively. The phenomenon has been seen as a means of concentrating limited resources on symbolically maintaining the sanctity of life in the affordable identified cases. Calabresi, Toward a Theory of Tragic Choices, April 1973 (lectures at U. Pa. Law School) [hereinafter cited as Calabresi, Tragic Choices]. Zeckhauser has described the myth as an all-or-nothing proposition (either life is beyond price or it isn't), calling it an "on-off variable." Overspending on identified lives, then. results from an "effort to maintain the variable in an on status. ." Zeckhauser, Catastrophic Illness, supra note 78, at 164. Neither of these formulations fully describes the reason as well as the result.

It is difficult to improve significantly on the more commonplace observations that human beings cannot empathize with faceless abstactions and that "squeaking wheels"-the complaints of known victims, such as the very vigorous lobbying of kidney-disease patients-not the silence of statistical unknowns, will get the governmental grease. Spending "millions of dollars to save a fool who has chosen to row across the Atlantic has external benefits" lacking from highway safety spending. Calabresi. Commentany, in Ethics of Health Care 48, 53 (L. Tancredi ed. 1974). For one thing, the single rescued rower will give a more dramatic and moving interview than millions of better protected motorists.

In any case, although many decisions, particularly in health and safety matters, reflect implicit finite valuations of human health and life. the importance of our society's belief in the sanctity of life should not be undervalued. Institutional arrangements for the financing of catastrophic illness must take this into account. Sep generally section V infra. But sep (. Fried. Medical. EXPERIMENTATION 69 (1974) (rejects "utterly" any "preference for the immediate and palpable [victim] over the statistical" solely to symbolize "concern for the individual" but supports such preference on other grounds). 
overtly to deny such an important value would impose significant costs not only on the politically vulnerable decisionmakers themselves but also on the society as a whole, whose faith in the benignity of government would be shaken. Yet such damage to the fabric of society is threatened whenever society directly confronts what Guido Calabresi calls "tragic choices" ${ }^{2}$-that is, dilemmas which require either overt sacrifice of a fundamental tenet, such as the sanctity of life, or the acceptance of such large costs of other kinds that this alternative will not seem satisfactory either.

Where "tragic choices" are confronted, the manner in which decisions are made may significantly influence the substantive outcome. Thus, when a case like that of Karen Quinlan becomes a public issue, ${ }^{83}$ a considerable overlay of symbolism may affect the decision whether to keep her "alive." 84 The decisionmaking process, whether formal or informal and whether consciously designed or simply evolved over time, largely determines the degree to which society's deeply held symbolic values come into play in particular cases, and this circumstance provides the policy analyst with a crucial insight: "There may be important results that stem from the choice of one procedure rather than another for assigning values to human life. And the decision whether to make this valuation process either visible or explicit may itself have a significant effect on the ultimate value assigned to human life." 85

Calabresi points out that some "tragic choices" are in fact finessed by society. This can occur when society's mores and institutions do not require that such choices be openly formulated and explicitly faced. As an example, Calabresi notes the operation of subtle societal pressures and incentives which ultimately determine the number of children individual families will have. ${ }^{86}$ The important point is that these choices occasion little or no discontent because there is no single, visible mechanism of choice. ${ }^{87}$ He argues, however,

82. "Tragic choices" arise in "situations where there is no right decision" because of conflicting fundamental values, and include, for example. deciding who shall be picked to fight in a limited war or who shall be allowed to use a limited number of kidney machines. Calabresi. Commentary, supra note 81 . Calabresi. Tragic Choices, supra note 81 .

83. In re Quinlan, 70 N.J. 10.355 A.2d 647 (1976), discussed in section IV.D. infra.

84. When "death" occurs or should be deemed to occur is a complicated question. See generally section IV.A. infra. But expert witnesses generally agreed that Karen Quinlan was "alive" under prevailing legal and medical definitions. Sep notes 231-33 infra and accompanving text. But of. Lachs, Humane Treatment and the Treatment of Humans, 294 New ENG. J. Ned. 838 (I976) (sometimes prospects for "life" may be so bad, as for very severely deformed newborns, that they should not be treated as persons).

85. Blumstein, Constitutional Perspectives on Government Decisions Affecting Human Life and Health, 40 Law \& Contemp. Prob. 233 (1976).

86. Calabresi, Commentar, supra note 81 , at 54.

87. When, however, the results of private decisions are particularly consequential and unusual circumstances bring them into public focus, considerable discontent may arise. See Tsukahara \& Siegel, Case Studies in Bioethics: Baby Making and the Public Interest, Hastings Ctr. Rep. Aug. 1976, at 13 (debate on propriety of choosing hazardous fertility-drug pregnancy, intentionally passing on to group insurance plan the great financial risk). 
that once tragic choices become explicit-are dragged into the open, as it were-no formal decisionmaking mechanism can be wholly stable over the long run, since each decision will be unsatisfying in some respect, either breaching some core societal value, such as equality, or perhaps just costing too much and offending our preference for efficiency. ${ }^{88} \mathrm{He}$ foresees a dynamic process of continual, cyclical change: Protesters will argue that a certain value is being ignored, prompting modification to take it into account but thereby sacrificing some other value, whose defenders will eventually appeal successfully for its reassertion. In this way, no important value or interest need be permanently sacrificed, and at least some of the demoralization costs which would flow from final rejection of a fundamental value are avoided by the prospect of its restoration.

Among the institutions Calabresi suggests to help avoid obvious breaches of fundamental values are "a-responsible" decisionmaking bodies, like juries, which, while in a sense representative, are not held publicly accountable or compelled to explain either their factual conclusions or the values which they apply. ${ }^{89}$ Such an institution is an attractive one for making some "tragic choices" because it lessens the likelihood of offending public sensibilities -precisely because it does not articulate priorities and keeps the basis of its decisions unclear. ${ }^{90}$ Moreover, government itself can effectively be kept in the background as long as these nongovernmental bodies have clearly circumscribed authority and draw legitimacy from tradition and consensus as well as from their legal mandate. ${ }^{91}$

Because direct government involvement in catastrophic medical care raises the prospect of inordinate spending in very many cases pursuant to the lifesaving imperative, it is arguable that government should seek to remain in the background as much as possible, playing its role in such a way as to avoid the destructive symbolic effect of its identification with specific human suffering. This would mean carefully selecting among a variety of agencies and

88. Calabresi. Tragic Choices, supra note 81. Although "it mav [sometimes] be desirable for society to spend an inordinate amount on each of a few lives to preserve a comforting myth." cost concerns are always present. Zeckhauser, Valuing Lives, supra note 78. at 447.

89. Calabresi, Tragic Choices, supra note 81

90. Cf. Leckhauser. Valuing Lites. supra note 78, at 458: "In situations in which the lives-fordollars tradeoff can be fuzzed over, decisions to sacrifice lives can be less discomforting." $B u t$ of. sources cited at notes 92-94 infra (favoring open and explicit due process) and accompanying text.

91. Although informal mechanisms such as those influencing family size may evolve and acceptably make implicit choices without people's being aware of them, similar decisionmaking by responsible agencies may be difficult to establish as a matter of conscious policy, since the acceptability of decisions made with limited accountability appears to depend on a legitimizing consensus and tradition, which cannot be fabricated. Nevertheless, some existing institutions already have a claim to legitimacy as a-responsible decisionmakers-the affected individual himself, his family, and his physician, for example-and might be allowed to continue bearing responsibility for some difficult choices. 
types of procedures for decisionmaking, deferring as much as possible to nongovernmental action, and giving government a generally low profile.

A policy of governmental nonassertiveness and delegation of flexible decisionmaking powers is not without risks, however. Failure to articulate openly and in easily understood terms what values are to be assigned to whose life -and on what criteria-might sometimes produce inefficient or inequitable results. One commentator recognizes that, "[g]iven that many of our received values deny the possibility of ranking the worth of individual human lives, it would conceivably be safer to conceal the process of decision from the public"; she nonetheless prefers openness because it allows comment, criticism, and perhaps "more efficient spending on medical resources." 92 In a similar vein, Jay Katz and Alexander Capron express their "preference for open, "visible' decisionmaking." They acknowledge that the "complex and hard choices" made in tragic situations may have a "less devastating impact on members of society and its institutions if they are arrived at by 'low visibility' rather than 'high visibility' decisionmaking." But they opt for "open" decisionmaking because of their concern about the potential for hidden abuse, "particularly of those groups within society who are traditionally the objects of neglect and mistreatment." 93

As government's role in these matters becomes attenuated, there is indeed an increased risk that the decisions made will be insufficiently sensitive to some core societal goals, since private decentralized decisionmaking always allows and indeed contemplates some inconsistency. ${ }^{\mathbf{9 4}}$ But it is our belief that this risk is outweighed by the advantages of decentralization, the very flexibility of which allows decisions to be open, visible, and accountable when so desired-as might be elected in a particular hospital, for example. Decentralized decisionmaking on the issues confronted in treating catastrophic disease would help to reduce both the nonpecuniary (but significant) costs to society of breaching important values through governmental action and the pecuniary costs of obeisance to symbolic values. It would also preserve the image of government as the provider of funds rather than the arbiter of life, while allowing private choice of and experimentation with different techniques for resolving tragic situations. The importance of not relying exclusively on governmental mechanisms for cost control in this difficult area may be illustrated by existing mechanisms for controlling health care costs and the

92. Note, Due Process in the Allocation of Scarce Lifesazing Medical Resources, 84 YALE L.J. 1734, 1749 (1975) [hereinafter cited as Note, Due Process].

93. J. Katz \& A. Capron. Catastrophic Diseases 3 [hereinafter cited as Katz \& Capron]. See also id. at 178-79, 189-92, 194-95, 217

94. Private decisionmakers may also use criteria that would be unacceptable if employed by government officials. See Sections III.C. \& IV. D. infra and accompanying text. Cf. Note, Scarce Medical Resources, 69 Colum. L. Rev. 620, 635 (1969) (favoring allocation of scarce resources under clear legislative guidelines, without which there is only "a collection of ad hoc procedures which may not serve any worthy values at all"). 
likely extent of their effectiveness in dealing with the costs of treating catastrophic disease.

\section{B. Current Cost-Control Strategies and Their Limitations}

Cost-sharing requirements and flat dollar or categorical limits on the coverage of public financing programs of the type found in some of the proposals outlined earlier are not the only cost-limiting strategies available to the health care system. Some more selective mechanisms are already in place or are being implemented under recently enacted legislation. ${ }^{95}$ In addition to offering hope that some obviously unnecessary health care spending can be curbed, these mechanisms provide some opportunities for reducing the provision of marginally beneficial care whose cost nevertheless exceeds a reasonable estimate of its benefit. It is quite possible, however, that these cost-control techniques will be less effective in dealing with catastrophic disease treatments than in dealing with the routine medical practice for which they are primarily designed. Indeed, those charged with implementing these approaches will have particular difficulty, given the lifesaving imperative, in forthrightly facing up to the benefit-cost issues presented by demands for medical management of life-threatening disease.

\section{Health Planning and Controls on Investment}

One important cost-control device currently in use is regulatory control over new capital investments in health facilities and equipment and over the introduction of new health services. Such regulation exists in over half the states, those already having so-called "certificate-of-need" laws, ${ }^{96}$ and will soon be universal as a result of obligations imposed on the states by the National Health Planning and Resources Development Act of 1974. ${ }^{97}$ Certificate-ofneed requirements have been primarily employed to rationalize growth and prevent duplication of services, but they might also be used to impose strict resource constraints on providers of care, forcing them to ration available facilities so that the clearest needs are attended to and more doubtful demands are not. ${ }^{98}$ It is thus at least theoretically possible to compensate through regulation for the system's weak cost consciousness by introducing resource constraints based on health planners' estimates of the amount of re-

95. This section reviews existing programs, not all potential cost-containment strategies. For brief discussions of other proposed cost-containment techniques, see note 111 and section $\mathrm{V}$. infra.

96. Am. Med. Ass' N, State Health Legislation Rep. 12 (Nov. 1976) (32 states had such laws as of August 1976). See generally Havighurst, supra note 17; Salkever \& Bice, The Impact of Certificate-of-Need Controls on Hospital linestment, 54 Milbank Mem. Fund Q.: Health \& Soc'y 185 (1976).

97. Pub. L. No. 93-641, 88 Stat. 2225 (codified at 42 U.S.C. $\$ 300 k-300 t$ (Supp. IV 1974)).

98. See generally Curran, A National Suriey and Analysis of State Certificate-of-Need Laws for Health Facilities, in Regulating Health Facilities Construction 85 (C. Havighurst ed. 1974). 
sources required to meet essential needs without inviting "unnecessary care" and "overutilization."99 It is relevant to consider whether planning-cumregulation can be counted upon to impose any reasonable limit on a societal commitment to the financing of medical care for catastrophic disease.

A strict limitation on the number of hospital beds, probably the most achievable cost-control measure, is unlikely to have much impact on the treatment of catastrophic disease, since patients with serious illnesses can be expected to get high-priority treatment in any event. ${ }^{100}$ On the other hand, limitation of facilities which are more closely associated with catastrophic care than are hospital beds could be expected to affect the provision of catastrophic care somewhat more significantly. For example, without regulatory restraint and with unlimited financing for treating catastrophic disease, hospitals would probably expand their intensive-care units (ICUs) to accommodate all potential patients at peak loads. Under regulation, the health planners might well be able to divert some of those resources to meeting needs they consider more important even if a few potential ICU users had to wait or were denied access altogether and even if an occasional death occurred in the queue.

Although responsibility for the adverse health consequences of planning decisions may sometimes be sufficiently diffused to minimize the effect of the lifesaving imperative, powerful forces continue to push decisionmakers away from effective overall cost control. Since the decisionmakers are not themselves responsible for paying the costs of care, they have no strong reason to implement rigorous cost counting. Providers and advocates for interests most directly affected are frequently able to invoke the lifesaving imperative with skill and impact, and the planners are understandably reluctant to offer in rebuttal benefit-cost analyses featuring specific values for the lives to be saved or lost or for the varying qualities of human life affected. ${ }^{101}$ Even though the

99. But see Salkever \& Bice, supra note 96 (hospital spending seems little affected).

100. This is apparently the case in Britain, where stringency results from limiting both beds and budgets. See section V.C. infra. According to a former Secretary of State for Social Services, "all the priority" is on "prolonging life in desperate cases" and not on "enabling healthy people to do their work by removing minor things which are wrong with them. . ." R. Crossman, A Politician's View of Health Service Planning 26 (1972). See also Bosanquet. Inequalities in the Health Serice, 17 New Soc'y 809 (1971): "This evidence also suggests that the NHS may be showing a bias towards more elaborate, specialized and technologically advanced types of care and neglecting less glamorous care." $I d$. at 912.

101. See generally Marmor, Wittman \& Heagy, Politics, Public Policy, and Medical Inflation, in Health: A Victim or Cause of Inflation? Recently another public group did overtly refer to the value of life. The Council on Wage and Price Stability opposed pending standards governing workers' exposure to emissions from coke ovens, arguing that the regulations "implicitly assign a value to human life" that is "extremely high, considering the amounts spent in other health and safety areas." Wall St. J., May 12, 1976, at 4, col. 2. The Council may have been able to take this unusual stance in part because it is only advisory, having no operational authority and lacking accountability to any identifiable political constituency. Notably, however, no explicit lower value of 
planners, distant from actual medical decisions, are in a better position to consider lifesaving in statistical terms and to focus on overall health benefits and costs, advocates for more and better services can easily castigate such analysis as callous, can frequently introduce anecdotal evidence to personify the victims, and can dramatize potential life-and-death issues in the media. ${ }^{102}$ Such tactics are likely to be quite effective, given the highly political environment of health planning. The planners' best defense is to frame issues in "either-or" rather than "yes-no" terms, so that conferring a particular health benefit is clearly seen to require denying another benefit and is not simply perceived as costing merely dollars, which are raised impersonally from a large number of taxpayers and premium payers, each of whom is only very slightly affected. It is not yet clear whether the mode of administration of the new system of planning and regulation will lend itself to framing issues in this way. ${ }^{103}$

Although saying "no" to new investments in health facilities will rarely be easy-except perhaps where unused, duplicative capacity would be createdplanners will probably have particular difficulty in limiting the supply of equipment which is used to treat only a single disease. Unlike the case of the ICU, which serves a variety of patients, a limited supply of disease-specific equipment compels treatments to be allocated among patients who seem to be similarly situated medically, thus inviting concern about discrimination. The seeming unfairness of saving only some of the victims of an identifiable disease is simply too great for health planners either to ignore or deny. ${ }^{104} \mathrm{Be}$ cause explicit rationing of lifesaving treatments on any basis is nearly intolerable to contemplate, the only viable alternatives will usually be for planners either to approve enough facilities to treat everyone or to treat no one with a particular condition. ${ }^{105}$ However, local planners are likely to find it difficult to

life was specified; even so, the reporter noted the agency's "awkward position" in opposing efforts to save steelworkers from cancer because it says the costs are too high." Id. See also note 102 infra.

102. This indeed occurred in the coke oven emission controversy discussed in note 101 supra. The United Steelworkers of America promptly derided the Council on Wage and Price Stability for "putting dollars ahead of human values" and implying that "the lives of coke oven workers aren't worth saving," Id.

103. See Havighurst \& Blumstein, supra note 5, at 33-35. See also section V.C. infra. If Health Systems Agencies rely heavily on their long-range, areawide health systems plans in reviewing individual projects, the system could emphasize "either-or" decisionmaking; if most decisions are made on a more ad hoc basis as approval for each project is sought, the "yes-no" approach could predominate.

104. See Calabresi, Tragic Choices, supra note 81.

105. For a discussion critical of the ethical proposition that "all should die when not all can be saved," see P. Ramsey, The Patient as Person 259-66 (1970). The idea that medical benefits, especially under public programs, should be equally available to all people similarly situated under medical criteria is nonetheless a deep-seated one-a viewpoint which lends support to a program of federal financing on a disease-specific basis. See section IV.B.2. infra; but see note 28 supra. 
deny their region expensive benefits available in other regions (and perhaps financed by nationwide taxes). ${ }^{106}$ Moreover, any refusal by local planners to provide services for catastrophic disease victims may simply cause patients to migrate to an area where facilities are available. ${ }^{107}$ Even one major medical center possessing new equipment or providing a new service-initially as a research endeavor but eventually as a regular service-would represent a leak in the health planning system, a leak which could quickly become a flood if an open-ended insurance program would pay providers for the catastrophic costs of ultra-sophisticated care, wherever provided. ${ }^{108}$

In this climate, planning for certain types of service would have to be coordinated at the national level ${ }^{109}$ unless society could be content with the rationing arhieved by high travel costs and by the comparative disadvantages of some in obtaining information on the availability of such treatments and the needed referrals. New forms of treatment, typified by coronary bypass surgery, ${ }^{10}$ would have to receive some kind of national clearance before their

Some commentators favor other means of allocating limited lifesaving efforts-including randomization or judgments of social worth. See, e.g., Childress, Who Shall Live When Not all Can Live?, 13 Soundings 339 (Winter 1970). The Seattle experience of weighing social factors in selecting kidney dialysis patients prior to nearly universal federal funding is often seen as highly undesirable. See, e.g., Rettig, supra note 1, at 196. Note, Scarce Medical Resources, supra note 94, at $658,622-66$.

106. Cf. Blumstein, Inflation and Quality: The Case of PSROs, in Health: A Victim or Cause of Inflation: 245, 283-85 (M. Zubkoff ed. 1976) [hereinafter cited as Blumstein, The Case of PSROs] (local PSROs have no incentive to deny their areas' claims for federally funded services to save money at a national level).

107. The right to migrate and settle is a "fundamental interest" entitled to a high degree of constitutional protection. See Dunn v. Blumstein, 405 U.S. 330 (1972); Shapiro v. Thompson, 394 U.S. 618 (1969). In particular, a state cannot condition its support of nonemergency medical services for indigents on their length of residence in a county. Memorial Hosp. v. Maricopa County, 415 U.S. 250 (1974).

108. A recent news story provides an international analogy. Washington Post, June 26, 1976. at A8, col. I. Under Holland's national health insurance plan. access to complicated heart surgery-largely controversial by pass operations, see note $110 \mathrm{infra}$-has been limited. The seven medical centers performing such procedures have been able to accommodate only 1,600 of the 6,000 patients who "need" them each year. After Houston's Dr. Denton A. Cooley was persuaded to accept Dutch patients at his Texas Health Institute (which performs some 5,500 operations a year), a Dutch lobbying group won an agreement for their government to pay for such operations in Texas-at a cost, including air fare, about the same as that incurred in Holland. The ensuing publicity has prompted the Dutch government to open wo new centers for heart surgery. Id.

109. Cf. Havighurst \& Blumstein, supra note 5, at 47-51 (need for federal oversight of PSROs).

110. The bypass operation replaces one or more diseased coronary arteries with a transplant of a patient's own healthy arteries. It is controversial for several reasons. (1) It is very expensive-about $\$ 10,000$ per operation. New Studies Should Settle Bypass Surgery Debate, 235 J. Am. MED. Ass'v 895 (1976) [hereinafter cited as New Siudies]. (2) There are many potential patients, perhaps up to 4 million candidates. McClure, supra note 55, at 24 . Sixty thousand operations were projected for 1976. New Studies, supra. (3) The procedure's efficacy in prolonging lives is not well established, although higher risk patients (with multiple-vessel disease) appear to have lower mortality with surgery than with medical treatment. See Corday, Status of Coronary Bypass Surgery, 231 J. Am. MEd. Ass's 1245 (1975); Mundth \& Austen, Surgical Measures for Cormary Heart Disease, 293 New Eng. J. Med. 124. 125 (1975). But see Selden, Neill, Ritzmann, Okies \& Anderson, Medical Versus Surgical Therapy for Acute Coronary Insufficiency, 293 New Enc. J. Med. 1329 
costs could be made reimbursable, and new types of equipment would have to be subjected to premarket screening not only for safety and efficacy but also for cost effectiveness. ${ }^{11}$ As yet, the mechanisms for imposing such controls

(1975) (small randomized study showed higher short-run mortality after surgery). (4) Coronary artery disease is progressive and cannot be cured by surgery, although painful symptoms of angina can be alleviated for some years. See Nezi Studies, supra. Further operations may be needed. (5) Despite symptomatic and functional improvement, surgical paticnts often do not return to work. Rimm, Barboriak, Anderson \& Simon, Changes in Occupation After Aontocoronary Vein-Bypass Operation, 236 J. AM. MED. Ass'v 361, 363 (1976) (bypass patients returned to work at same rate as survivors of heart attack).

111. It is, however, undeniably difficult to suppress even very costly technology, once it has developed beyond the experimental stage and doctors and patients have learned of it. A priori restraint of technological research and development may thus seem to be the best control. Indeed, the high cost of treating catastrophic disease would not be a policy issue of its curremt magnitude but for the astonishing recent advances in medical science. Technological proliferation may now be outpacing not only our ability to pay for it but also our careful consideration of its other effects on our way of life (and death). See section IV.A. infra. Policy analysts are beginning to question the wisdom of unbridled-indeed, heavily subsidized-medical research and development. See sources cited note 65 supra.

The essential concern is that existing technology develops its own lobby and nearly irresistible pressure for its widespread, even universal. adoption-at public expense. if necessary. Ser gener. ally Calabresi. Tragic Choices, supra note 81 . One response to this insight is to review proposed research, either addressing dispassionately in advance the eventual benefits and costs of achieving particular research goals or establishing general guidelines or criteria for the same purpose. Undesirable technology could theoretically be nipped in the bud, thereby successfully limiting its application to catastrophic disease. This would save considerable investment and treatment resources and patients would not need to be denied access to known therapies by planners fiat. PSRO order, or simple lack of cash.

Effectuating such a system poses some problems. Even though public spending supplies almost two-thirds of medical research dollars. Public Health Service. U.S. Dep't of Health. Educ. \& Welfare, Forward Plan for Health FY 1977-81, at 62 (June 1975), controlling research through federal funding has not proved effective, and private investment stimulated by a universal system of governmentally endowed entitlements would further weaken federal leverage. Sep note 65 supra and accompanying text. Control over private sector research could not be achieved without a drastic change in the regulatory environment. Denving rembursement for treatment modalities resulting from disapproved research-after the analogy of health planning-might well be insufficient, and outright prohibition of research, perhaps with criminal sanctions, might prove necessary. Such restraints on the freedom of thought and investigation would offend deeply rooted and constitutionally recognized values, making administrative problems, themselves immense, seem to pale in comparison. For an argument favoring freedom of inquiry with respect to recombinant DNA research (gene manipulation), see, e.g., Cohen, When May Research Be Stopped?, 296 New Engl. J. Med. 1203 (977). But see, e.g., Goldstein, Public-Health Policy and Recombinamt DNA, 296 NEW ENGL. J. MED. 1226 (1977) (favors caution and reasonable restraint).

Nonetheless, interest in imposing some constraints on technology mav well continue w grow. and any detailed proposals will merit serious consideration as a supplenent to more direct costcontainment approaches. But such control is at best a partial and long-term hope. Even a total moratorium of further research-a highly unlikely prospect-would not affect the application of existing knowledge, and currenty available or developing technology is probably far enough advanced already to call forth vastly expanded treatment expenditures, if sufficient resources become available. Selective controls would face the difficult problem of predicting where basic research will lead, and a new breakthrough might. on balance. just as easily be beneficial as detrimental. See note 66 supra. Controls could be limited to applied research and development, whose outcomes are more predictable, but even here advance judgments on the desirability of proposals would be extraordinarily difficult 6 make, if only because of the manifold ramifications involved: witness the struggles of the government panel trying to decide only whether to fund development. not universal availability. of the artificial heart. Sep Artificial Heari Assessment Panel, supra note 6. As difficult as it will be to implement effective health planning 
have not been devised, though the developing PSRO program is a candidate to assume the responsibility for establishing national policy on new therapies and the utilization of equipment of questionable value. ${ }^{112}$

\section{Professional Standards Review Organizations}

Professional Standards Review Organizations (PSROs) are federally mandated regional organizations of practicing physicians assigned responsibility for supervising the utilization and quality of inpatient care under the Medicare and Medicaid programs. ${ }^{113}$ Though few PSROs have yet become fully operational, many proposals have already suggested that they be maintained as cost and quality monitors under national health programs. ${ }^{114}$

PSROs are charged with assuring that federally funded health care services are medically necessary, meet professional standards, and are rendered in the proper institutional setting. ${ }^{115}$ They will act both as rulemakers and as adjudicatory agencies, establishing general guidelines for medical practice and also reviewing specific cases for compliance. ${ }^{116}$ Variances from general guidelines may be allowed if found justified in particular cases; otherwise, compliance is to be enforced by withholding federal payment for the disallowed services. ${ }^{117}$ PSRO review does succeed in keeping government itself from intruding in individual medical decisions, but PSRO's may nevertheless be perceived by many doctors as a form of government interference, even though they are largely under the control of local physicians. ${ }^{118}$

PSROs were designed primarily to regulate not catastrophic care but the more routine care that occasions the bulk of current federal health spending. Their principal cost-related concerns are preventing unnecessary hospital admissions and setting and enforcing length-of-stay standards for typical diagnoses. The standard of "medical necessity" which they are to employ is not likely to lead them, at least at the outset, to question what and how much care

and controls on investment, it would be an order of magnitude more difficult to carry out comprehensive controls on research. Some technological restraints might serve as one component of an overall cost-containment strategy, but such controls probably cannot succeed as the major element of such a strategs.

112. Another means of control is suggested by the recent Medical Device Amendments of 1976, Pub. L. No. 94-295, 90 Stat. 593 [codified in scattered sections of 5, 21 U.S.C.], which requires administrative approval of certain medical devices prior to marketing.

113. 42 U.S.C. \& 1320c et seq. (Supp. IV 1974). See generally Blumstein. The Case of PSROs. supra note 106: Havighurst \& Blumstein, supra note 5.

114. E.g. H.R. 14079 \& S. 2513, 93d Cong., 1st Sess. (1973); H.R. 12684 \& S. 2970. 93d Cong, 2d Sess. (1974) in 1974 Hearings, supra note 41. at 262. See. e.g. Greenberg, PSRO-On the Way. But to Where, 290 New. Eng. J. Med. 1493 (1974).

115. 42 U.S.C. $\$ 1320 \mathrm{c}-4(\mathrm{a})(1)$ (Supp. IV 1974). Sep Blumstein. The Case of PSROs, supra note 106. at $263-67$.

116. Ser Havighurst \& Blumstein, supra note 5. at 52-54.

117. 42 U.S.C. \$ 1320c-9 (Supp. IV 1974). See Blumstein, The Case of PSROs, supra note 106. at $288-90$.

118. Se Havighurst \& Blumstein, supra note 5, at 57 and n.196. 
for seriously ill patients is properly paid for under federal programs. ${ }^{119}$ Moreover, PSROs are to enforce professional rather than social norms, ${ }^{120}$ and cases of catastrophic illness will seldom present obvious problems under this standard. Also, because PSROs have no stake in the cost consequences of their decisions, they are unlikely to weigh cost as heavily as potential patient benefits in evaluating any level of care, routine or catastrophic. ${ }^{121}$ But, with extensive governmental financing of catastrophic disease treatments, cost issues will ultimately have to be addressed in some way.

PSROs are likely to have great difficulty in setting proper limits in dealing with catastrophic, life-threatening cases. In adjudicating the appropriate level of catastrophic care in a particular case, PSRO reviewers will frequently confront an individual patient whose survival is arguably dependent on treatments already begun and whose doctor is urging continuation of those treatments. ${ }^{122}$ The lifesaving imperative applies with full force here: The survival and well-being of an identified patient will appear to hang upon the PSRO decision, and PSROs in such circumstances will face enormous pressure to avoid overtly placing a limited value on such lives. Moreover, PSRO physicians will have nothing to gain from saying "no" and nothing to lose by saying "yes" to continued treatment. PSROs have no authority either to reallocate or to capture any cost savings they achieve, ${ }^{123}$ savings which accrue instead to the federal treasury. Although strong federal oversight might bring more cost consciousness to bear, it is still uncertain whether PSROs will be required to reflect national policy in their norms. ${ }^{124}$

119. Id. at 43. The notion of medical necessity, however, can be made to reflect some degree of economic awareness. See id. at 31-33. Stuart \& Stockton. Control oier the Utilization of Medical Serices, 51 Milbank Mem. Fund Q.: Health \& Soc'y 341. 342-43, 359-76 (1973).

120. 42 U.S.C. \$1320c-5(a) (Supp. IV 1974). See Blumstein, The Case of PSROs, supra note 106. at 282 .

121. Blumstein. The Case of PSROs, supra note 106, at 283-86; Havighurst \& Blumstein, supra note 5 , at $66-68$.

122. Although the statute authorizes prior review, 42 U.S.C. \$ 1320c-4(a) (2)(B) (Supp. IV 1974), PSROs will typically consider whether a specific therapy is necessary and appropriate only after treatment is begun. DHEW's implementing guidelines emphasize concurrent and continuing, periodic reviews. Bureau of Quality Assurance, Health Services Admin.. Public Health Service, U.S. Dep't of Health, Educ. \& Welfare, PSRO Program Manual $\$ \$ 701,705$ (1974). Moreover, a patient's doctor will ypically support continued therapy: otherwise. the issue could not arise for PSRO review, since only physicians may order hospital treatment.

The difficulty of publicly ceasing catastrophic, life-sustaining treatment once begun is shown by the Quimlan case, discussed in section IV.D. infra. Karen Quinlan was irreversibly comatose, and her parents sought court approval for removing life-supporting machinery against her physicians' wishes. The opposition by the State of New Jersey to discontinuing life support under those circumstances indicates just how difficult it could be for a PSRO's quasi-governmental reviewers to oppose treatment in the more usual case where patients or relatives as well as doctors seek continued funding. See generally In re Quinlan. 70 N.J. 10. 355 A.2d 647 (1976).

123. See Blumstein. The Case of PSROs, supra note 106, at 256-58, 290-92: Havighurst * Blumstein, supra note 5 , at $50-51$.

124. Blumstein. The Case of PSROs, supra note 106, at 256-58. 290-92; Havighurst \& Blumstein, supra note 5 , at 47-49 and $n .166$. 
Given these influences on their decisions in cases of catastrophic illness, PSROs would probably be able to refuse further financial support only where there was virtual professional unanimity that treatment is ineffective and wasteful. ${ }^{125}$ Indeed, the lifesaving imperative might still be difficult to overcome unless this consensus had been previously formulated in a clear rule directly applicable to the case and therefore did not have to be faced as a matter of first impression in the context of a particular patient's case. Thus, although providers are understandably concerned that PSRO rules will engender "cookbook medicine," the rulemaking function of PSROs may increase their ability to consider the value of catastrophic treatments dispassionately -in abstract statistical terms rather than with respect to identified patients. ${ }^{126}$ If decisions were made in this way, PSRO decisionmakers might be persuaded to view themselves not as arbiters of life and death itself but simply as delineators of federal reimbursement policy-that is, as particularizers of the proper scope and coverage of welfare programs designed to provide decent and adequate, but not unlimited, care to large populations at reasonable cost. ${ }^{127}$ Moreover, because PSROs' performance of their rulemaking function is more easily supervised by federal authorities than are their adjudicative activities, federal policy emphasizing statistical analysis and careful balancing of benefits and costs could be more readily implemented. On the other hand, PSRO doctors, as advocates for patient interests, could serve as an effective counterweight to possibly excessive concern for cost at the impersonal federal level and thereby help to achieve a proper balance.

Prediction of the ultimate impact of the PSRO program is difficult, but the prospects for approaching an optimal level of health care spending seem poor. To date, the medical profession has vigorously promoted the lifesaving and quality-of-care imperatives, causing federal administrators of the PSRO program to change the program's primary emphasis from cost control to quality assurance. ${ }^{128}$ Indeed, many anticipate increased rather than decreased

125. Indeed, the former head of the PSRO program spoke in just such terms: "PSRO is not a cost-control program-it is a waste control program. . . "Address by Dr. Henry Simmons, "PSRO and the Quality of Medical Care." before the Indiana Medical Association, May 16, 1974 [hereinafter cited as Simmons speech]. Waste control concerns only unproductive and counterproductive treatments, ignoring the difficult and important decisions regarding marginally productive care. Id. See Havighurst \& Blumstein, supra note 5, at 17-18 \& Figs. la \& 1b. See also Blumstein, The Case of PSROS, supra note 106, at 264-65, 286-87; notes 70-75 supra and accompanying text.

Professional consensus that a "patient" was technically dead could also ease a cut-off of federal funding. See section IV.A. infra.

126. See Havighurst \& Blumstein, supra note 5, at 52-54. The lifesaving imperative is strongest where identified patients are involved. See notes 75, 78, 79 supra and accompanying text.

127. See Blumstein, The Case of PSROs, supra note 106, at 288-90; Havighurst \& Blumstein, supra note 5 , at 54-58 \& n.196.

128. Quality Assurance in Hospitals 4 (R. Egdahl. P. German. C. Taft \& D. Giller eds. 1976); Havighurst \& Blumstein, supra note $\mathbf{5}$, at $40-45$. 
costs as a result of giving doctors such power to regulate themselves. ${ }^{129}$ Oriented by training, tradition, and the nature of their practice ${ }^{130}$ (and in some cases by their economic and professional self-interest ${ }^{131}$ ) to perceiving medical care in "micro" rather than "macro" terms-that is, as a problem of protecting individual patients' lives and health rather than as a problem of allocating society's resources to their best use-doctors are powerful antagonists in any quality-versus-cost debate. Moreover, PSRO decisions are structured so that issues are perceived only in "yes-no," never in "either-or," terms. ${ }^{132}$ PSROs, integrated as they are likely to be with the infrastructure of organized medicine, may thus become lobbyists for more and better services and for perpetuating the medical tradition that cost should be no object when health and particularly life itself may be at stake. ${ }^{133}$

\section{Health Maintenance Organizations}

A promising nongovernmental mechanism for containing the cost of health care while maintaining good quality is the Health Maintenance Organization (HMO). ${ }^{134}$ The special feature of HMOs is their commitment to provide all needed care for a fixed price paid in advance. ${ }^{135}$ The consequent

129. Under PSROs, "the total cost of medical care in this nation may well rise, and if it does, it will not mean that PSRO has failed. Total cost is not the key issue." Simmons speech, supra note 125. According to another DHEW official. PSROs could "induce a ratcheting up process, in which the most expensive levels of care would become the norms." Interview with $\mathrm{S}$. Fleming, DHEW Ass't Sec'y for Policy Development, Am. Med. News, Feb. 26, 1973, at 3. See also Quality Assurance in Hospitals, supra note 128 , at 10.

130. Havighurst \& Blumstein, supra note 5, at 25-28.

131. Blumstein. The Case of PSROs, supra note 106, at 270, 286. Nearly open-ended financing by third-party payers (including Medicare and Medicaid) encourages physicians to achieve the best care technically possible for their patients with little attention to weighing benefits and costs. "This is a comfortable position for the physician. The arrangement is made even more cozy by the coincidence of the physician's pecuniary interest with the welfare maximization interest of the patient." Id. at 270 . See also McClure, supra note 55 , at 25.

132. See Havighurst \& Blumstein, supra note 5, at 33-34, 36, 50-51, 53, 63

133. "Indeed, instead of serving as watch-dogs on behalf of the public at large. PSROs might well become potent, and virtually unopposed, political instruments for increasing rather than containing costs." Id. at 66. See also Stone, Professionalism and Accountability: Controlling Health Services in the United States and West Germany, J. Health Politics, Policy \& Law (forthcoming 1977).

134. Dr. Paul Ellwood and his colleagues at the Institute for Interdisciplinary Studies (InterStudy) in Minneapolis coined the term "HMO" to include prepaid group practice. foundations for medical care, and other organizations with similar incentives. E.g. Ellwood, Anderson, Billings, Carlson, Hoagberg, \& McClure Health Maintenance Strategy, 9 MED. Care 291 (1971). See generally Institute of Medicine, Nat'l Academy of Sciences, HMOs: Toward a fair Market Test (policy statement, 1974); Egdahl, Foundations for Medical Care, 288 New Eng. J. MEd. 491 (1973); Havighurst, Health Maintenance Organizations and the Market for Health Services, 35 LAw \& Contemp. Prob. 716 (1970); McNeil \& Schlenker, HMOs, Competition and Government, 53 Milbank Mem. Fund Q.: Health \& Socy 195 (1975).

135. This section is concerned with the cost-containing abilities of HMOs, which conventional wisdom attributes to prepayment. See generally sources cited note 134 supra. Some analysts, however, now attach as much importance to the incentives of group practice as to those of prepayment alone. Gaus, Cooper, \& Hirschman, Contrasts in HMO and Fee-for-Service Performance, SocIAL 
necessity for allocating the fixed pool of subscriber prepayments to achieve the most benefit for subscribers is thought to lead HMOs to strive for efficiency and to pursue only the most cost-effective treatments. More than any other element in the health care system, HMOs face "either-or" choices and must decide whether particular treatments or particular risk-reducing measures, including those for catastrophic diseases, are better investments than, say, better prenatal care or consumer health education. For these reasons, HMOs would seem well situated to make the difficult decisions which are needed if health care costs are to be reasonably controlled.

Unlike the typical private health insurance plans with which they compete for subscribers, HMOs are heavily committed to caring for catastrophic illness under their basic contractual undertaking to provide all needed care. Nevertheless, some HMOs have expressly excluded coverage of organ transplants, psychiatric services beyond a certain amount, and long-term care. ${ }^{136}$ Moreover, their contractual obligations would probably be construed to cover only what was standard in the community, so that exotic treatments such as heart transplants or other measures still in the experimental stage would not have to be supplied at plan expense. ${ }^{137}$ By the same token, expanded coverage of catastrophic illness in the fee-for-service sector would probably cause an expansion of HMOs' obligations unless varied in some way by contract.

Without the incentives to overtreat which are implicit in third-partyfinanced fee-for-service medicine, HMOs have featured less hospitalization and lower overall costs than the fee-for-service sector. ${ }^{138}$ Their performance probably reflects in part some success in reducing hospital stays in the treatment of catastrophic disease and in employing outpatient and nursing home facilities to good advantage. Despite their success in controlling these costs, HMOs are inhibited in several ways from appropriately omitting in the name of economy any measures which, if taken, might arguably increase by even the smallest amount the probability of recovery or survival in catastrophic cases. For one thing, the law of medical malpractice, drawing its standard of care from medical practice in the larger fee-for-service marketplace, might

SeCurity Bull., May 1976, at 3; The Biggest H.M.O. Advocate Backs off on Prepayment, MediCal Economics, Aug. 9, 1976, at 29 (interview with Dr. Ellwood). Finally, it should be noted that many HMO supporters view the cost-containment capabilities of HMOs as far less important than the potential of HMOs to increase access to and quality of care. See Havighurst \& Bovbjerg, Professional Standards Review Organizations and Health Maintenance Organizations: Are They Compatible?, 1975 UTAH L. Rev. 381, 383-87.

136. See J. Kress \& J. Singer, HMO Нandbook 114-15 (1975); Yohey, Developing a "Benefits" Package, in Health Maintenance Organizations: Proceedings of a Conference, 1972, at 49 (Medical Group Management Ass'n, 1972).

137. See Bovbjerg, The Medical Malpractice Standard of Care: HMOs and Customary Practice, 1975 DukE L.J. 1375, 1386-88 \& n.36.

138. See generally Donabedian, An Evaluation of Prepaid Group Practice, 6 Inquiry, Sept. 1969, at 3; Roemer \& Shonick, HMO Performance: The Recent Evidence, 51 Milbank Mem. Fund Q.: Health \& Soc'y 21 (1973). 
penalize and thus deter all omissions, even those which were justified on benefit-cost grounds, by requiring damages to be paid whenever a jury thought that the omission did not conform to standards of customary practice and contributed to an injury or death. ${ }^{139}$ In addition, regulatory oversight by PSROs may also force HMOs to adopt prevailing fee-for-service practices. ${ }^{140}$ Finally, a reputable $\mathrm{HMO}$ must be concerned about its public image, which would be damaged by any allegation of corner-cutting in the treating of lifethreatening illness. ${ }^{141}$ Each of these problems can be expected to become substantially greater as the fee-for-service sector comes to provide ever more expensive catastrophic care in response to increased insurance coverage.

Despite these handicaps, HMOs remain a most promising cost-control mechanism. ${ }^{142}$ If (a big if in the current climate) consumers in the future are left any reason to consider cost in selecting a health care plan, HMOs could play an important role in holding down costs to their subscribers and perhaps, through competition, in the fee-for-service sector as well. Reasonable HMO innovations and departures from majority practice should therefore be acceptable, even in the treatment of catastrophic disease. Both legally and operationally, however, HMOs are now far from being in a position to supply the needed check on health care cost escalation. Other mechanisms will have to be relied on, at least in the short run, to control costs under a scheme of catastrophic coverage.

\section{The Impact of Due Process Requirements}

The difficulty of making sensitive decisions on the care of particular desperately ill individuals - or even on the allocation of resources to lifesaving purposes in general-could be greatly increased if constitutional procedural "due process" requirements were held to apply. The more deeply government becomes involved in decisions about the initiation, conduct, and termination of catastrophic disease treatments, the more likely it is that such constitutional guarantees of fair procedures-applicable only to governmental action-could

139. Bovbjerg, supra note 137, at 1389-1407.

140. See Havighurst \& Bovbjerg, supra note 135, at 401-11.

141. An HMO's economizing efforts can readily be characterized as unjustified stinting on patient welfare, especially where life may be at stake or where the HMO or its doctors appear to profit in any way from the savings. Public authorities, consumer advocates, plaintiffs law'yers, and fee-for-service physicians (either supporting quality at any cost or simply opposing their HMO competitors) will thus find it easy to stigmatize any departures from customary practices. Only HMOs with very secure reputations or explicit subscriber acceptance of their policies will be able to take even the most appropriate gambles with the health or lives of patients. Even wellestablished health plans apparently regard themselves as less free than fee-for-service doctors to "pull the plug" on a moribund patient. Possibly HMOs which are organized as cooperatives or otherwise have significant consumer participation could more realistically assess the worth of particular increments of expensive care in critical cases.

142. Other approaches featuring closed-end financing similar to that of HMOs are discussed in Section V.C. and the Conclusion infra. 
be invoked by or on behalf of a patient whose constitutionally protected interests would be threatened by an adverse decision. ${ }^{143}$ If procedural due process requirements were applied, great complexities might be introduced, and the impact of the lifesaving imperative might be substantially increased, for decisions would then be subject to the glare of publicity, making a stance seeming to deny or qualify the sanctity of life difficult to maintain.

It is not clear precisely what the due process clause, if applicable, ${ }^{144}$ would be held to require in the circumstances of decisionmaking on financing catastrophic disease treatment. Because such decisions are highly sensitive and complex and frequently must be made under intense time pressure, the courts would be well advised not to press the requirements too far, despite the importance of the patient's interest. In recognition of exigencies such as these in other settings, courts have been flexible in delineating procedural requirements in varying contexts, and could be expected not to be too demanding here. ${ }^{145}$ Nevertheless, a number of troublesome problems would be encountered even if only the most minimal requirements of notice and hearing were routinely imposed. ${ }^{146}$

Among the other requirements which might be mandated under the due process clause is prospective specification of standards through rulemaking, a way of confining discretion that might otherwise be abused. ${ }^{147}$ Similarly, decisionmakers might be required to make explicit findings of fact and to explain their reasons for actions taken. ${ }^{148}$ In the context of catastrophic illness,

143. U.S. Const. amend. V.: "No person shall . . be deprived of life, liberty or property, without due process of law. . . . U.S. Const. amend. XIV, § 1: "No State shall . . deprive any person of life, liberty, or property, without due process of law. . ." See generally Blumstein, supra note 85 , at 238 . The protections of the due process clause (or the equal protection clause, note 184 infra) attach only if state involvement or accountability is sufficient to warrant a finding of "state action." See, e.g., Jackson v. Metropolitan Edison Co., 419 U.S. 345 (1974). Normally, a hospital's mere receipt of federal funds, for example, is not enough to subject it to due process requirements. Compare, e.g., Greco v. Orange Memorial Hosp. Corp., 513 F.2d 873 (5th Cir. 1975), cert. denied, 423 U.S. 1000 (1976) and Ascherman v. Presbyterian Hosp. of Pac. Med. Center Inc., 507 F.2d 1104 (9th Cir. 1974) (majority rule) with, e.g., Christhilf v. Annapolis Emergency Hosp. Assoc. Inc., 496 F.2d 174 (4ch Cir. 1974). See generally Greco v. Orange Memorial Hosp. Corp., 423 U.S. 1000 (1976) (dissenting opinion). See also PuB. L. No. 93-45, § 401(b), (c), 87 Stat. 95 (codified at 42 U.S.C. § 300a-7 (Supp. IV 1974)).

144. Courts must find not only state action but also an interest in life, liberty, or property before due process safeguards are applied. It is not altogether clear that a decision adverse to a patient seeking lifesaving treatment would be held to have deprived him of such an interest, but a strong argument to that effect could be mounted. See Blumstein, supra note 85. at 239: Note, Due Process, supra note 92.

145. See, e.g., Goss v. Lopez, 419 U.S. 565 (1975) (school suspensions); Wolff v. McDonnell, 418 U.S. 539 (1974) (withdrawal of prisoners' credit for good time served).

146. Once it has been determined that due process is required, the issue becomes what process is due. See Mathews v. Eldridge, 424 U.S. 319 (1976); Gagnon v. Scarpelli, 411 U.S. 778 (1973). Notice and hearing are the most basic requirements. See Blumstein, supra note 85 , at 241; Note, Due Process, supra note 92, at 1744 \& n. 53.

147. See generally K. Davis, Discretionary Justice (1969).

148. See, e.g., Goldberg v. Kelly, 397 U.S. 254 (1970); Holmes v. New York City Housing Authority, 398 F.2d 262 (2d Cir. 1968). 
however, detailed articulation of standards and reasons pursuant to such requirements would be highly objectionable: Not only would it gravely interfere with medical practice, ${ }^{149}$ but it would also require both explicit ordering of sensitive priorities and overt interpersonal comparisons, which are bound to have significant demoralizing effects in an egalitarian democratic society. ${ }^{150}$ In life-and-death cases, adherence to such procedural requirements could amount to legalistic indecency. ${ }^{151}$

Although courts usually make an effort not to impose procedural requirements which are unduly burdensome, ${ }^{152}$ the difficulties addressed here could be more surely avoided if the decisions made or the actions taken were found to be not governmental, but private-that is, found not to constitute "state action" within the meaning of the fourteenth amendment. ${ }^{153}$ The locus of decisionmaking is thus of paramount importance in determining whether life-and-death decisions will be dragged into the open for all to see and for lawyers to contest by the many means at their disposal. As later discussion will reveal, recent Supreme Court decisions have evidenced a willingness to recognize a large realm of private behavior which is not subject to procedural requirements. This suggests that structural arrangements which allow wide scope for private decisionmaking in the provision of care will allow government to finance catastrophic medical care and yet avoid the worst distortions attributable to the lifesaving imperative. ${ }^{154}$

IV

Maintaining Government's Distance From Life-and-Death Decisions:

The Effect of Legal Doctrine

Public attempts to contain health care costs thus risk direct government involvement in individual tragic choices; this involvement, in turn, inevitably creates pressure for ever-increasing spending on catastrophic disease. ${ }^{155} \mathrm{But}$ government's involvement in a human death or suffering can be greater or less depending on how the financing program is structured and how resource constraints are given effect. Our sense is that government ought, if possible, to discharge its responsibilities without placing itself in the position of having to accept apparent responsibility for every delayable death and preventable

149. Cf. Planned Parenthood of Cent. Mo. v. Danforth, 428 U.S. 52, 75-79 (1976) (Court invalidated prohibition on use of saline amniocentesis technique of abortion, in part because it arbitrarily interfered with prevailing medical practice).

150. See notes 88-90 supra and accompanying text.

151. But of. Note. Due Process, supra note 92 (favors such requirements).

152. See, e.g., Goss v. Lopez, 419 U.S. 565 (1975).

153. See note 143 supra.

154. See section IV.B. \& n. $182 \mathrm{infra}$

155. Cf. Cooper, Health Costs and Expenditures in the United Kingdom, in International. Heal.TH Costs and Expenditures 93. 102 (Teh-Wei Hu ed. 1976) (Fogarty Int'l Ctr. for Advanced Study in the Health Sciences). (As the "provision gap" between what medical services are possible and which are available becomes more obvious, pressures for increased services, arise.) 
hurt. Such distancing of government from decisionmaking is directly at odds, however, with a widely held belief that openness, explicitness, and accountability are always virtues which should not be compromised ${ }^{156}$ and that government has a responsibility to monitor delivery of the services it finances so as to impose consensually derived, uniform standards of conduct. Nevertheless, deep governmental involvement may have high costs, including not only potentially excessive dollar outlays but a moral and political toll as well. ${ }^{157}$

Avoiding governmental entanglement requires judicial and legislative ingenuity in allocating decisionmaking authority between the public and private sectors and in designing programs of public support. In dealing with catastrophic disease, this may mean entrusting broad discretion to such private decisionmakers as patients, their families, and physicians or to more formal but still "a-responsible" agencies, such as hospital ethics committees. Careful preservation of areas of private responsibility might be dictated by, among other considerations, a pragmatic sense that government and courts can do no better in making sensitive decisions, that openly debating such decisions on the "merits" would be socially demoralizing and ultimately inconclusive, and that, in the absence of anything approaching a consensus on such highly charged questions, it is better to agree to disagree, leaving people to act privately in accordance with their own beliefs and preferences.

The law determines the extent of the state's involvement in private decisions affecting life and death in many ways, and doctrinal changes could be made to shield certain such decisions from close public scrutiny. The legal definition of death is one influence; an altered definition might clarify the acceptable scope of medical decisionmaking with respect to some moribund patients. The law of torts and criminal law also influence how catastrophic care is provided and might be adjusted in subtle ways to make more secure the current range of private discretion. The most important potential legal developments, however, are those of constitutional law. Judicially developed constitutional principles could define a realm of less closely supervised action, both 1) by confining the reach of constitutional obligations through narrowing the "state action" concept and 2) by employing the "right of privacy" to demarcate an area protected against governmental intrusion. It is useful to consider how certain legal doctrines bear at least indirectly on the problem of catastrophic disease costs and on the need to achieve an appropriate balance between public and private decisionmaking in this emotion-laden area.

\section{A. Definitional Approaches}

The legal definition of death was, until quite recently, of remarkably little significance, a matter one might simply look up in Black's Law Dictionary or

156. See, e.g., Katz \& Capron, supra note 93, at 3; Note, Due Process, supra note 92, at 1749

157. See Burt, Authorizing Death for Anomalous Newborns, in Genetics and the Law 435 (A. Milunsky \& G. Annas eds. 1976); Calabresi, Tragic Choices, supra note 81. 
Words and Phrases. Doctors traditionally determined when death occurred for most purposes. ${ }^{158}$ The time of death as a legal issue seems to have arisen principally in property disputes, such as in determining which of two joint tenants died first, allowing the other's heirs to claim the property. ${ }^{159}$ While courts fashioned rules for deciding such cases, scholars did not wrestle with the issue, and no one regarded it as momentous-that is, until the sudden appearance of cadaver organ transplantation sent everyone scurrying to the lawbooks, where they found only definitions formulated without much thought and for very different purposes. ${ }^{160}$ Increased interest in searching for a definition of death reflected in part a new doubt concerning the physician's trustworthiness: For nearly the first time, physicians faced a strong conflict of interests-a severe temptation to neglect one patient's rights in their haste to procure a transplantable organ for another. Whereas a physician had previously been viewed as wholly dedicated to his dying patient's welfare, he was now perceived as having developed a worrisome eagerness to get at the patient's vital parts. ${ }^{161}$

The definitional debate also shows the importance of language and perception in shaping policy. Applying the term "dead" to a particular physiological state is not merely a mechanical determination of fact by a physician or other decisionmaker, but is also a normative judgment implicating important social values. ${ }^{162}$ Clearly, our society could not countenance taking vital organs from a moribund but "live" donor who would thereupon "die." Popular per-

158. Black's Law Dictionary 488 (rev. 4th ed. 1968) recognizes "death" as being "defined by physicians." Sef also Friloux, Death, When Does It Occur? 27 Baylor L. Rev. 10 (1975).

159. See, e.g. In re Estate of Schmidt, 261 Cal. App. 2d 262.67 Cal. Rptr. 847 (1968) (whether husband and wife died simultaneously); Smith v. Smith, 229 Ark. 579, 587, 317 S.W.2d 275,279 (1958) (whether testators who named each other in their respective wills died simultaneously). See generally, Uniform Simultaneous Death Act, 8 U.L.A. 605 (1972).

160. Traditional definitions adopted for other purposes do little to clarify transplantation issues. See Katz \& Capron, supra note 93, at 205-17; D. Meyers. The Human Body and the Law 97-138 (1970): P. Ramsey. supra note 105, at 59-112. See generally Capron \& Kass, A Statutory Definition of the Standards for Determining Human Death: An Appraisal and a Proposal, 121 U. PA. L. REv. 87 (1972); Sadler \& Sadler, Transportation and the Law: The Need for Organized Sensitivitv, 57 GEO. L.J. 5 (1968).

161. See, e.g., Corday, Life-Death in Human Transplantation, 55 A.B.A.J. 629, 632 (1969):

$[\mathrm{C}]$ ertain actions by transplant surgeons in establishing time of death on death certificates and hospital records have shaken public confidence. Coroners have denounced them in the press for signing a death certificate in one county when the beating heart was removed a day later in a far off city. The public wonders what the "item" was that was transplanted across the state line and later registered as a person in the operating room.

See also Shillito. The Organ Donor's Doctor: A Nea Role for the Neurosurgeon. 281 NEw ENG. J. MED. $1071(1969)$.

162. Sep, e.g., Katz \& CAPron, supra note 93, at 211 ("The formulation of a concept of death is neither simply a technical matter nor one susceptible of empirical verification. The idea of death is at least partly a philosophical question, related to such ideas as 'organism,' 'human,' and 'living.' ") See also R. Veatch, Death, Dying, and the Biological Revolution $24-29$ (1976); Capron \& Kass, supra note 160; McCoy, Logic vs. Value Judgment in Legal and Ethical Thought, 23 VAND. L. REV. 1277 (1970). 
ceptions therefore had to be altered so that "dead" persons' organs could be used to restore life to others threatened by death. The same physiological state could then be permitted to justify transplantation, so long as the definitional label had been modified to conform to deeply held societal values regarding the sanctity of "life." 163 The new medical notion of "brain death"164 provided a useful definitional shield for the fundamental value choices necessitated by the decision to transplant organs.

This use of definition is one way that difficult life-and-death decisions have been kept from public scrutiny. The recent prosecution of Dr. Kenneth Edelin for "killing" an aborted (but arguably "live") fetus ${ }^{\mathbf{1 6 5}}$ highlights the political importance associated with definitional labels. The prosecutor convinced a jury that Dr. Edelin was guilty of killing a "person," but, in reversing, the Massachusetts Supreme Judicial Court held that only a fetus "born alive outside its mother" can be "a 'person' within the meaning of the [manslaughter] statute." ${ }^{166}$ The label "nonperson" has the comforting effect of allowing us to avoid the potentially shocking confrontation with the deeply held notion that taking a life is impermissible.

The larger public policy debate over abortion similarly reflects the importance of definitional perceptions. Like the Edelin prosecutor, "right-to-life" groups have acclaimed the fetus as a living "person," whose civil rights must be constitutionally protected. Those who favor permitting abortions counter that the fetus is not a "person" within the meaning of the Fourteenth Amendment, a position adopted by the Supreme Court in Roe \%. Wade. ${ }^{167}$ Either Edelin or Roe could have been resolved by a recognition that the fetus has the requisite elements of "personhood" but that abortion is nonetheless justifiable. This, however, would have risked a much more substantial breach of a basic tenet-namely, that the taking of life is illegitimate except in the most extreme circumstances. The definitional approach has the advantage of channeling disagreement into the process of categorization itself, not directly threatening fundamental belief in the sanctity of human "life."

The case of Karen Quinlan ${ }^{168}$ illustrates both the symbolic significance of

163. See generally McCoy, supra note 162. at 1290-94. For an express suggestion that the moral dilemma of whether to treat defective newborns be defined away, sue Lachs, supra note 84 . arguing that a "hydrocephalic" infant "is not a person. and the fundamental er ror of our ways consists in thinking that it is one." Id. at 839. But see Hevman \& Holu, The Severely Defective Newborn: The Dilemma and the Decision Process. 23 PuB. Policy 381, 415 (1975); Leflers to the Editor. $295 \mathrm{~N}_{\mathrm{EW}}$ Exg. J. MED. 115 (1976). In rebutal, Lachs conceded that he had meant "hydranencephalic" infants. but reiterated his major thesis. $/ d$. at 116 .

164. Harvard Medical School Ad Hoc Committee to Examine the Definition of Brain Death. Report: A Definition of Irreiersible Coma, 205 J.A.M.A. 337 (1968).

165. Commonwealth v. Edelin. 359 N.E.2d 4 (Mass. 1976). On the impact of the trial court conviction, see generally Abortion: The Edelin Shock Ware. TıмE Mar. 3, 1975, at 54; Culliton, Manslaughter: The Charge Against Edelin of Boston City Hospital, 186 SCience 327 (1974).

166. 359 N.E.2d at 12.

167. 410 U.S. 113,158 (1973).

168. In re Quinlan, 70 N.J. 10,355 A.2d 647 (1976). 
the life or death label and its limitations as a device for avoiding problems. Quite clearly, no question about the legality of disconnecting the respirator which was artificially maintaining her vital signs would have arisen if there had been a consensus that she was already "dead." Legal complications arose only because, by accepted medical standards (designed with organ transplantation in mind), Karen Quinlan was "alive."16! Yet, as the New Jersey Supreme Court realized, she was not living a normal and functional human life but rather was being maintained in an irreversibly comatose and "persistent vegetative state." 170 While insufficient for transplant "death," this was enough for the court to realize that the state's interest in preserving her existence was less substantial than it would have been if she had been medically salvageable. ${ }^{171}$ Although the court did not pronounce Karen Quinlan dead, it did allow her life support to be terminated, recognizing that she had a status akin to death, since she could not hope ever to recover. ${ }^{172}$

The Quinlan decision thus had to circumvent an inflexible definition of death. A less rigid and mechanical definition of death would have presented fewer doctrinal difficulties. A different approach could recognize that death is often more a process than an event ${ }^{173}$ and explicitly acknowledge that standards of death can indeed differ-that the conflict of interest involved in terminating life support to get a transplantable organ to benefit another patient dictates a more restrictive approach than allowing irreversibly comatose patients to die because continued life support is not in their own best interest. ${ }^{174} \mathrm{~A}$ court could thus acknowledge that someone like Karen Quinlan

169. All parties involved stipulated that Karen Quinlan was legally and medically "alive." 70 N.J. at 20,355 A.2d at 652 .

170. $70 \mathrm{~N} . J$ at $25-26,355 \mathrm{~A} .2 \mathrm{~d}$ at 655 .

171. 70 N.J. at $41-42,355$ A.2d at 664 .

172. 70 N.J. at 54,355 A.2d at 671 . Sep also note $232 \mathrm{infra}$. The notion of varying degrees of state interest thus achieves a flexibility in dealing with the process of dying not readily obtainable through the usual legal concept of a single instant of death. See note 173 infra.

173. For example, compare Morison, Death: Process or Ezent?, 173 Science 694 (1971) aith Kass. Death as an Event: A Commentary on Robert Morison, 173 Scievce 698 (1971). See also Shapiro. Organ Grafting in Man, 14 J. For. MED. 41.41 (1967): "[B]iologically we die in bits and pieces. Nor all parts of the body. . are equally 'dead' at the same time. Indeed it is this simple thanatological fact that makes organ transplant possible at all."

174. No onc definition is likely to be satisfactory for all purposes, and using different definitions in different circumstances would provide needed flexibility. It would not, however, reduce the difficulty of defining a precise instant of death during a protracted process of dying. Moreover, even where an official "bright line" could be dawn, thus permitting the taking of certain actions with respect to the body which would otherwise be troublesome, the same determination could underscore providers' doubts and fears about the medical management of patients who had not yet crossed the line. Finally, although lawyers may be comfortable in adopting different definitions of the same term according to the circumstances and the result sought to be achieved, see Dworkin, Death in Context, 48 IND. L..J. 623 (1973), many people might find it unseemly to adopt a variety of arguably artificial definitions for such a momentous determination.

Another approach to the definitional problem is to recognize that many decisions need not turn solely on whether a patient is "alive" or "dead." Thus, deciding when to cease treatment need not be seen as a problem of defining just when death occurs, but may be treated as a 
could be deemed "dead" for purposes of discontinuing heroic treatment. This approach might help to dampen the heated rhetoric that swirls around such cases. Moreover, it would restore to physicians much of their traditional authority to determine, as a "medical" matter, whether death has occurred and, in consultation with the family and perhaps a hospital committee, that treatment should therefore cease.

Redefining concepts of "death" is thus one way that physicians and family might be allowed to retain considerable discretion in dealing with these troublesome issues. Nevertheless, there are substantial limits to our ability credibly to define away difficult problems, especially for something so laden with implications as the word "death." 75 The stubbornness of the abortion controversy reflects the resistance the Supreme Court decision has generated by using this approach on a similar issue of deep moral significance. Despite the success of the redefinition of death in the transplant area, many delicate, intractable problems will not be easily resolvable through the use of labels.

\section{B. "State Action" and Government Involvement}

The imposition of constitutional due process requirements could worsen the socially debilitating side-effects of decisions on catastrophic care. Before constitutional safeguards under the fourteenth amendment apply, however, responsibility for specified conduct must somehow be assigned to the state. ${ }^{176}$ Criteria for establishing the existence of governmental answerability have recently been reexamined by the courts in a revival of interest in the so-called "state action" doctrine. ${ }^{177}$

One might not ordinarily think of medical decisions, made primarily by doctors, as involving governmental culpability. A determination by physicians to undertake one catastrophic procedure rather than another, or even to let a patient die rather than to undertake heroic measures, would not appear to implicate the state. But, as governmental financial and regulatory involvement in health care increases, ${ }^{178}$ treatment decisions might come to be seen as sufficiently implicating government to require application of constitutional stan-

separate issue to be decided upon different grounds-as the Quinlan court in fact did. See notes 171, 172 supra, 233 infra.

175. Although they disagree on the nature of death, Kass and Morison, for example, are allied in opposition to seeking solutions through "definitional wizardry." Kass, supra note 173, at 699: Morison, supra note 173, at 695.

176. See note 143 supra.

177. See, e.g. note 182 infra.

178. See, e.g., Greco v. Orange Memorial Hosp. Corp., 513 F.2d 873 (5th Cir. 1975), cert. denied, 423 U.S. 1000 (1976). See generally Weise v. Syracuse Univ., 522 F.2d 397 (2d Cir. 1975); Jackson v. Statler Foundation, 496 F.2d 623 (2d Cir. 1974), cert. denied, 420 U.S. 927 (1975); Wahba v. New York Univ., 492 F.2d 96 (2d Cir. 1973), cert. denied, 419 U.S. 874 (1974). 
dards. Medical decisions to turn off a respirator, or not to save a defective newborn, could then trigger an array of constitutional protections, since the decisions of the physician, even in his most private relation with patients, would be seen as a state responsibility.

It is perhaps unlikely that the state action principle would be pressed so far as to cover essentially private doctor-patient encounters. But in the hospital context, where most catastrophic care is rendered, physician decisions which in themselves would be deemed sufficiently private to escape the "state action" characterization might nevertheless occur in circumstances that would allow them to be seen as institutional decisions of the hospital. Then, if the hospital itself were a public institution or were considered to be acting under color of state law, application of constitutional norms would inexorably follow. ${ }^{179}$ This problem would be most obviously presented by a decision made by a physician who happened to be an employee of the hospital rather than an independent contractor, the more typical relationship. But increased institutionalization of decisionmaking about catastrophic treatments through "a-responsible" hospital committees ${ }^{180}$ or through the PSRO program could increase the probability that medical decisions would be deemed the responsibility of the hospital itself, a view that would find some precedent in the law of malpractice. ${ }^{181}$ Some decisions, of course, would appear more institutional than others. For example, institutional arrangements for rationing limited resources by selecting among individuals might seem to involve the hospital as an institution, even though the actual decisions might conform to traditional medical norms of triage, long practiced by physicians in the face of acute (short-term) resource scarcity.

Because of the high emotional and financial costs that would likely flow from judicial recognition that the tipping point toward government entan-

179. It is, of course, possible for the government to have significant involvement in some parts of an institution but only limited identification with other facets of its operation. For example, if one academic unit of an otherwise private university is publicly supported, then constitutional protections may be afforded to those associated with the state-supported school but not to those affiliated with the rest of the university. See Powe v. Miles, 407 F.2d 73, 81 (2d Cir. 1968) (To support a finding of state action, "the state must be involved not simply with some activity of the institution alleged to have inflicted injury upon a plaintiff but with the activity that caused the injury. ... [T] the state action, not the private action. must be the subject of complaint.") This line of authority would focus the state action inquiry on "whether there is a sufficiently close nexus between the State and the challenged action of the regulated entity so that the action of the latter may be fairly treated as that of the State itself. . ." Jackson v. Metropolitan Edison Co., 419 U.S. 345, 351 (1974). See also Moose Lodge No. 107 v. Irvis, 407 U.S. 163, 175-77 (1972). However, once state action is found-whether for the institution in all its activities or whether for an individual component-then the guarantees of the fourteenth amendment apply.

180. Cf. In re Quinlan, 70 N.J. 10, 355 A.2d 647 (1976) (ethics committee), discussed infra at note 252.

181. Recent years have seen a trend toward increasing institutional responsibility for injuries formerly attributed solely to physicians. See, e.g., Bovbjerg, supra note 137, at 1386-88 \& $\mathrm{nn}$. 37-38. 
glement had been passed, courts should hesitate to apply the state action doctrine too mechanically. Recently the Supreme Court has evinced an increased willingness to recognize a considerable realm of private behavior for which government is not held accountable. The state action concept no longer appears to reflect an expansive philosophy of pervasive government responsibility for perceived social inequities; recent decisions seem inclined to permit and even protect an area of private sector conduct for which governmental accountability (and authority) will be attenuated. ${ }^{182}$ Applying this approach to the provisions of catastrophic care would allow successful development of a strategy for maintaining government's distance from tragic choices. This technique might formerly have failed because of the view that the state had an affirmative, nondelegable duty to perform certain "governmental functions," but the Supreme Court has seemed distinctly disinclined to extend such positivistic notions and indeed has already begun to limit and overrule previous decisions in this area. ${ }^{183}$ Private decisions on what care should be rendered in catastrophic cases would seem a prime candidate for viewing as nongovernmental.

Although the state action doctrine could easily be interpreted to avoid much of the counterproductive interaction of due process requirements and the lifesaving imperative in catastrophic illness cases, findings of no state action would also rule out judicial scrutiny under the equal protection clause to prevent racial or other discrimination. ${ }^{184}$ The potential for unreviewable, possibly systematic discrimination is indeed troubling, but this concern is somewhat mitigated by the possibility that courts can find ways, in practice if not in theory, to view state action differently where racial discrimination is involved $^{185}$ and by the existence of statutory remedies against much private discrimination. ${ }^{186}$ In addition, even without constitutional or statutory obliga-

182. See. e.g., Jackson v. Metropolitan Edison Co., 419 U.S. 345 (1974) (despite strict regulation, government not responsible for actions of private utility company); Lloyd Corp. v. Tanner. 407 U.S. 551 (1972) (private shopping center not a public forum for exercise of freedom of speech): Moose Lodge No. 107 v. Irvis, 407 U.S. 163 (1972) (govermment issuance of liquor license insufficient to atribute private clubs racial discrimination to the state): Evans v. Abney, 396 U.S. 435 (1970) (enforcement by courts of discriminating provision of a private will does not constitute state discrimination). Cf. Pasadena City Bd. of Educ. v. Spangler, 427 U.S. 424 (1976) (private housing patterns creating residential segregation not the responsibility of the school board).

183. See Hudgens v. NLRB, 424 U.S. 507 (1976); Blumstein, supra note 85 at 238.

184. U.S. Const. amend. XIV, $\S 1$ : "No State shall ... deny to any person within its jurisdiction the equal protection of the laws." See note 143 supra.

185. See Jackson v. Statler Foundation, 496 F.2d 623. 628-29 (2d Cir. 1974), cert. denied, 420 U.S. 927 (1975); Grafton v. Brooklyn Law School, 478 F.2d 1137. 1142 (29d Cir. 1973); but see Jackson v. Metropolitan Edison Co.. 419 U.S. 345. 373-74 (1974) (Marshall, J., dissenting).

186. Several civil rights statutory remedies have either been enacted since 1964 or reinvigorated by the Supreme Court. Title VI of the 1964 Civil Rights Act, 42 U.S.C. \& 2000(e) (1970), bars discrimination by any entity that receives support from or contracts with the federal government-an extremely valuable safeguard, since federal financial assistance permeates the 
tions, both public and private hospitals will feel some public pressure not to make decisions arbitrarily and will adopt procedures which they feel defensible in the face of public opinion and legal attack under theories of tort or criminal responsibility. Moreover, the pressure for obtaining sufficient facilities to avoid the necessity for explicit and possibly discriminatory rationing in critical cases will be nearly overwhelming in any event. ${ }^{187}$ Thus, other social and legal controls may reduce the need for the additional protections of constitutional due process requirements.

\section{Legal Liability and Vital Medical Decisions}

\section{Tort Law}

Only recently has tort law begun to impinge upon sensitive decisionmaking in catastrophic medical care, especially critical or terminal care. Given the variety of theories under which potential plaintiffs might seek legal redress with respect to care given to dying patients, it is surprising that so few have ever done so, especially since medical advances have provided physicians with so many means of affecting the time and manner of "death," however defined. ${ }^{188}$ With the ever growing sophistication of medical technology and medical litigants, more legal concerns are likely to emerge in the future, particularly if more generous funding leads some people to expect more heroic medical efforts than seem desirable to providers of care.

The current malpractice "crisis" has made doctors and hospitals acutely aware of their potential legal liabilities, ${ }^{189}$ and their vague fears of suit and

medical sector in general and the research and hospital subsectors in particular. Indeed, the mere threat of enforcement through cut-off of federal funds could be enough to prompt an institution to seek accommodation rather than risk its financial integrity by confrontation.

Even discrimination not resulting from state action may have statutory remedies. Although aimed primarily at hotels and motcls, Title 11 of the 1964 Act could plausibly be applied to discrimination by a hospital, as an "establishment which provides lodging to transient guests," 42 U.S.C. \$ 2000a(b)(1) (1974)-a provision the Court has seemed to construe broadly. See. e.g. . Daniel v. Paul, 395 U.S. 298 (1969) (snack bar and recreational facilities held to make lake resort such an "establishment"). Moreover, ever since Jones 7. Alfred H. Mayer Co.. 392 U.S. 409 (1968). the Supreme Court has given far-reaching interpretations to Reconstruction Era civil rights legislation. Most recently, the Court has interpreted 42 U.S.C. $\$ 1981$ (1970), which guarantees all persons the same right of contract enjoyed by white citizens, to bar racial discrimination by private parties. Runyon v. McCrary, 427 U.S. 160 (1976) (private schools). Cf. Griffin v. Breckenridge, 403 U.S. 88 (1971) (no "state action" required for suits under 42 U.S.C. $\$ 1985(3)$ (1974)).

187. See text accompanying notes $104 \& 105$ supra.

188. Doctors allowing patients to die might be sued for negligence, wrongful death, abandonment, or breach of an implied contract to do everything possible to sustain life. Few cases have been reported. At least one civil suit has been brought, Tucker v. Lower, No. 2831 (Richmond, Va., L. \& Eq. C.., May 23, 1972), discussed in R. VEATCH, supra note 162, at $21-24$ et passim, Katz \& Capron, supra note 93, at 213-15. See also The State of Life-and-Death Lau: Chaotic, National Observer, Aug. 21, 1976, at 4, col. 3 (suit for removal of decedent from respirator said "first ever").

189. E.g., U.S. Dep’t of Health, Educ. \& Welfare, Medical Malpractice: Report of the Secretary's Commission 20 (1973) [hereinafter cited as DHEW, Medical Malpractice]; Malpractice in Focus (An AMA Source Document prepared by the editors of Prism, 1975). 
their cautious lawyers' advice in this area may be further advanced than the actual state of litigation. "Defensive medicine"-undertaking particular diagnostic or therapeutic procedures more for legal protection than for medical benefit-is apparently enough of a problem with regard to superfluous lab tests and the like in everyday medical care. ${ }^{190}$ Should it become prevalent in catastrophic care, not only high costs but also unwarranted suffering for terminal patients and their families could result. To some extent, the PSRO statute may provide a valuable safeguard against any such trend. Since adherence to PSRO norms immunizes a provider from malpractice liability for failure to undertake procedures beyond PSRO norms, ${ }^{191}$ PSROs might help providers avoid extravagant care-provided that PSROs could be persuaded to find that certain heroic measures, which might otherwise be undertaken for legal protection, were not medically necessary.

Moreover, liability fears even more than ethics and medical tradition may lead physicians to neglect the wishes of patients and families ${ }^{192}$-forestalling, for example, obedience to the terms of a "living will." Such a will encourages providers to adhere to a patient's own previously expressed wishes about the nature and extent of catastrophic medical care to be provided. Early versions were simple documents which arguably failed to present enough information to elicit truly informed, reflective choices, taken with awareness of their importance. But recent versions are more sophisticated, ${ }^{193}$ and California's

190. See, e.g., DHEW, Medical Malpractice, supra note 189, at 14-15; Welch, Medical Malpractice. 292 NEW ENG. J. MED. 1372, 1375 (1975).

191. 42 U.S.C. $\$ 1320 c-16$ (c) (Supp. IV 1974); See generally Carter, Medical Malpractice Immunity: A Realistic Prognosis for the Social Security Acts Cinil Immunity Provision, 47 Miss. L.J. 621 $(1976)$

192. One nationwide poll of randomly selected physicians found that two-thirds named "legal constraints" as factors which "might keep them from acceding to a [terminally ill] patient's wishes" about care, whereas only one-fifth listed "ethical constraints." 94.5 per cent nonetheless said they try to follow a patient's expressed wishes. Am. Med. News/Impact, Jan. 24, 1977, at 3, col. 4. Although theoretically a physician must always obtain informed consent to treatment from his patients or their surrogates, see note 224 infra, in practice a doctor (or hospital) has great control over the style of practice undertaken, especially in the routine management of patients. Moreover, informed consent need not be obtained in emergencies. E.g., A. Holder, Medical Malpractice LaW 227 (1975).

193. For example, compare Kuttner, Due Process of Euthanasia: The Liting Will, A Proposal, 44 Ind. L.J. 539 (1969) with Bok. Personal Directions for Care at the End of Life. 295 NEw ENG. J. Med. 367 (1976). See also Note. Informed Consent and the Dving Patient, 83 Yale L.J. 1632, at 1663-64 \& nu. 174-75 (hereinafter cited as Note. Informed Consemt). Providers reliance on even a sophisticated "living will" may still be criticized for not anticipating a particular eventuality and for not allowing signers to change their minds. Of course, any involuntary treatment decision is less satisfactory than contemporaneous informed consent. but perfection is unatainable by any proxy decisionmaker-whether family, doctor, or court-and in this light the "living will" is more acceptable.

The law properly view's with unease any involuntary cessation of treatment allegedly based upon the prior consent of an incompetent patient, and courts should demand good evidence of its seriousness and informed nature. Thus, in the Quimlan case, discussed infra, both trial and appellate courts dismissed as inconclusive evidence that the comatose patient had repeatedly said 
Natural Death Act ${ }^{194}$ recently legitimized the use of a similar but more formal "Directive to Physicians."

The California statute creates a carefully limited "right to die"195 and constitutes a first step in assuring legal protection for providers who wish to honor individual decisions to terminate heroic medical treatment. The Act finds that "adult persons have the fundamental right to control . . . the decision to have life-sustaining procedures withheld or withdrawn in instances of a terminal condition." 196 Any competent adult may execute a directive asking that life-sustaining procedures for terminal conditions be withheld or withdrawn. Providers acting pursuant to a patient's directive, executed under the protective safeguards of the statute, ${ }^{197}$ are immunized from civil or criminal liability. Although no provider is obligated to follow the patient's directive, a physician's "failure to effectuate the directive . . . shall constitute unprofessional conduct if the physician refuses to make the necessary arrangements, or fails to take the necessary steps, to effect the transfer of the . . patient to another physician who will effectuate the directive ...."198 The California Act thus eliminates any need to act in professional self-defense rather than to abide by uncoerced, rationally articulated patient choices.

Because catastrophic and especially terminal care present such personal, value-laden issues, state courts, applying common law principles, should recognize that a single objective community standard of care may well be too inflexible and that consensual arrangements should be fostered to accommodate the variety of human responses in this sensitive area. ${ }^{199}$ Courts will of

that she never wanted to be kept alive by extraordinary means. In re Quinlan, 137 N.J. Super 227, 260, 265, 348 A.2d $801,814,819$ (1975), 70 N.J. 10,41, 355 A.2d 647,664 (1976). A well-executed and sophisticated living will offers rather more safeguards in this regard than evidence from informal past conversations. But. for an argument that a broad-based panel should rule on whether to accépt any such will, see R. Butrer. Why Survive? Being Old in America 378-79 (1975).

194. Cal. Health \& Safety Code $\$ \$ 7185-7195$ (West Supp. 1976).

195. See note 218 infra and accompanying text.

196. Cal. Health \& Safety Code $\$ 7186$ (West Supp. 1976).

197. Cal. Health \& Safety Code $\$ 7188$ (West Supp. 1976)

198. Cal. Health \& Safety Code $\$ 7191($ b) (West Supp. 1976).

199. Malpractice law has typically required providers to follow the standard of care prevailing in a given locality, e.g., $1 \mathrm{D}$. Louisell \& H. Williams, Medical Malpractice 9.06 (1973)potentially including how much effort to make in catastrophic cases. However, since so much acute or catastrophically expensive care is the province of hospital-based medical specialists. a uniform nationwide standard might be applied. See, e.g., Naccarato v. Grob. 384 Mich. 248, 180 N.W.2d 788 (1970). In either case, a single objective standard would not be applied if the practice objected to (say, refusing to undertake potentially life-prolonging measures) were followed by a "reputable" or "respectable" minority of providers. E.g., 1 D. Louisell \& H. Williams, supra. at 9 8.04.

Clear judicial acceptance of consensual determination of care in appropriate cases would nonetheless be helpful in motivating providers to follow their patients wishes rather than undue malpractice fears. Cf. Epstein, Medical Malpractice: The Case for Comiract, 1976 A.B.F. ReSEARCH J. 87 (favors more consensual approach generally). 
course have a central role in assuring that consent is conscientiously sought and freely given.

\section{Criminal Law}

Although its precise effect is impossible to quantify, the criminal law both embodies our society's high valuation of life and bolsters the lifesaving imperative in medical care. Indeed, implementing medical decisions whose normal and natural consequence may be death is theoretically homicide. ${ }^{200}$ Yet providers of catastrophic medical care do and must routinely make such decisions, and even a remote legal threat doubtless has some impact on doctors treating critically ill patients. In practice, providers probably have very little reason to fear the application of criminal sanctions, but simple nonenforcement and looking the other way-as prosecutors and others have routinely done in the past ${ }^{201}$ - may no longer suit the tenor of the times. ${ }^{202}$ The lifeand-death decisions necessitated by advanced medical technology are becoming more and more frequent and visible to the public at large, and several recent events suggest that such treatment decisions will not always be kept out of the public domain and the criminal courts. ${ }^{203}$

Some degree of safety for decisionmakers may be sought through doctrinal subtlety. For example, allowing a patient to die without undertaking heroic life-sustaining efforts might be characterized as an omission rather than an act. ${ }^{204}$ But such distinctions probably provide insufficient security for

200. See, e.g., G. Whlliams, The Sanctity of Life and the Criminal Law 261-64, 326 (1956); Survey, Euthanasia: Criminal, Tort, Constitutional and Legislative Considerations, 48 NOTrE Dame Law. 1202. 1203, 1213. 1229 (1973) [hereinafter cited as Survey, Euthanasia]. See also D. MEyers, supra note 160 , at $150-52$.

201. See generally, D. Maguire, Death by Choice 23-24 \& n.5 (1975); Survey, Euthanasia, supra note 200 , at $1203,1213,1229$.

202. The same kind of considerations that lead many to press for "open" procedures to make life-and-death decisions, see note 156 supra and accompanying text, would support more public resolution of similar issues in criminal law as well.

203. Among these are the Edelin case, supra note 165 , and the decision by the Attorney General of New Jersey to intervene in the Quinlan litigation. In re Quinlan, 70 N.J. 10, 19-20; 355 A.2d $647,651-52(1976)$.

204. See, e.g. D. Maguire. supra note 201, at 45-46; Fletcher, Prolonging Life, 42 Wash. L. REv. 999, 1008 (1967). However. since medical providers have a duty to treat patients, even omission may be culpable, unless the duty is somehow limited. Notions of customary standards of care might set boundaries to criminal as well as civil liability, see note 199 supra, or the duty could be limited to providing "ordinary" care. See, e.g., Robertson, Involuntary Euthanasia of Defective Nouborns: A Legal Analvis, 27 STAN. L. REv. 213, 235-37 (1975). What constitutes “ordinary" care is. however, highly subjective. See, e.g., P. RAMSEY, supra note 105, at 118-32; R. VEATCH, supra note 162, at 106-10. Alternatively, the notion of patient consent could be borrowed from civil law to limit the doctor's duty to providing desired care. Here the legal hurdle is the maxim that one cannot consent to murder. See, e.g. Survey, Euthanasia, supra note 200, at 1205.

Other legal subtleties could also be relied upon: (1) The cause of death might be held to be the underlying catastrophic condition rather than the lack of care. Compare Elkinton, The Dying Patient, The Doctor, and the Law. 13 VILL. L. REv. 740, 743 (1968) and In re Quinlan, 70 N.J. 10, $51-52.355$ A.2d 647. 670 (1976) with Robertson, supra, at 237-39. (2) The doctrine of necessity 
physicians, patients, and public alike. ${ }^{205} \mathrm{~A}$ better approach is to protect some private decisions from public scrutiny. Living wills and the California statute $^{206}$ accomplish this to some extent. A more thoroughgoing way of achieving this result is considered next-the possibility of recognizing constitutional limits on the power of the state to intrude upon such personal and family decisions.

\section{Constitutional Delineation of Private Realms- Karen Quinlan and Beyond}

In structuring government's role in catastrophic illness, it would prove profitable to build upon our society's experience in dealing with other important symbolic issues. Our constitutional system does, for example, limit governmental intrusions into some religious or quasi-religious affairs because of the very real dangers which flow from government's involvement. ${ }^{207}$ Thus, a restricted sphere for public action has been laid down by the establishment of the religion clause of the Bill of Rights ${ }^{208}$ and by the Supreme Court in cases involving contraception ${ }^{209}$ and abortion. ${ }^{210}$ These recognitions that it is sometimes desirable for government to be kept at a distance from the swirl of unresolvable policy problems may carry over to other areas, such as catastrophic disease, where appearances, symbolism, and individually held fundamental values often dominate substantive outcomes. ${ }^{211}$

The first amendment's prohibition against the establishment of religion gave constitutional effect to its ratifiers' experience that governmental interference in or involvement with religion endangered not only religious institutions but democratic ones as well. Whereas the free-expression provisions of the first amendment ${ }^{212}$ adopt the view that an open marketplace of ideas most constructively channels disagreement and resolves political conflict, the

might be invoked. Compare Robertson, supra, at 239-43 with Williams, Euthanasia and Abortion, 38 U. Colo. L. REv. 178, 183 (1966). (3) The quality of intent or motive legally required for criminality could be re-examined. See, e.g., D. Maguire, supra note 201, at 37-41.

205. See, e.g., Fletcher, The Patient's Right to Die. Harper's, Oct. 1960, at 138, 143 ("a very cloudy distinction"); Morison, supra note 173, at 696-97 (distinction is as arbitrary as the position of zero on Fahrenheit temperature scale); Note, Informed Consent, supra note 193, at 1649-50 (1974) (not a distinction, but a continuum).

206. See notes 193-98 supra and accompanying text.

207. See generally. Tribe, The Supreme Court, 1972 Term-Foreword: Tou'ards a Model of Roles in the Due Process of Life and Lau', 87 HaRv. L. Rev. I (1973).

208. U.S. CONST. amend. I: "Congress shall make no law respecting an establishment of religion...", see, e.g. Lemon v. Kurtzman, 403 U.S. 602 (1971).

209. E.g., Eisenstadt v. Baird, 405 U.S. 438 (1972); Griswold v. Connecticut, 38 l U.S. 479 (1965).

210. E.g., Planned Parenthood of Cent. Mo. v. Danforth, 428 U.S. 52 (1976); Roe v. Wade, 410 U.S. 113 (1973); Doe v. Bolton, 410 U.S. 179 (1973).

211. See section III.A. supra.

212. U.S. Const, amend. I: "Congress shall make no law... abridging the freedom of speech, or of the press...." 
establishment clause embodies a judgment that public decisions arrived at through exchange of ideas and majority vote are inappropriate where the issues may involve faith more than reason. The establishment clause therefore removes religion from the political realm, thus avoiding the permanent divisiveness that could result from the drawing of political battle lines according to religious convictions. ${ }^{213}$ In establishment clause cases, government is admonished not to become "entangled" in religion because of the substantial risk to democratic and religious institutions alike in permitting any significant interrelationship between them. ${ }^{214}$

Contraception and abortion are examples of intensely debated issues with significant religious or quasi-religious undercurrents. One important achievement of the Supreme Court's invalidation of state prohibitions in these areas has been to prevent government from having to take a side-“for" or "against"-in highly charged ethical controversies. ${ }^{215}$ Although many antiabortionists do not accept the state's position as ethically neutral in that controversy, technically, at least, abortion questions have been largely left to personal choice. Indeed, the intensity of feeling and unwillingness to compromise that permeate the abortion debate clearly demonstrate the dangers of politicizing such issues, with their strong overtones of personal ethical values and religious beliefs about the nature of life. Many issues involved in the treatment or nontreatment of catastrophic disease present similar concerns and cannot be resolved without violating some moral tenet which many people would not wish to see society offend. ${ }^{216}$

The abortion cases extended the scope of the constitutional interest in privacy to protect the right of a woman to decide, in consultation with her physician, to have an abortion. The state was in effect forbidden to prohibit or even to regulate early abortions, beyond requiring that they be performed by a licensed physician. ${ }^{217}$ This notion of a private realm free of state intrusions

213. In Lemon \%. Kurtzman, 403 U.S. 602 (1971), Chief Justice Burger noted regarding aid to parochial schools: "Ordinarily political debate and division, however vigorous or even partisan, are normal and healthy manifestations of our democratic system of government, but political division along religious lines was one of the primary evils against which the First Amendment was intended to protect." Id. at 622 .

214. Walz v. Tax Commn, 397 U.S. 664 (1970). "Entanglement" is a third test for whether government action constitutes establishment of religion, the other two being secular legislative purpose and principal or primary effect which neither advances nor inhibits religion. Bd. of Educ. v. Allen, 392 U.S. 236 (1968). In Lemon v. Kurtzman, 403 US. 602 (1971), the entanglement notion took on two dimensions, administrative and political, of which only the latter is of importance for this discussion. See Roemer v. Bd. of Public Works, 426 U.S. 736 (1976); Meek v. Pittenger, 421 U.S. 349, 373 (1975) (Brennan, J., dissenting).

215. See Tribe, supra note 207. But see Maher v. Roe, 45 U.S.L.W. 4787 (U.S. June 20, 1977) (state refusal to pay for nontherapeutic abortions under Medicaid not unconstitutional even when state pays for more expensive costs of childbirth).

216. See Burt, supre note 157; Calabresi, Tragic Choices, supra note 81 .

217. Under Roe v. Wade, 410 U.S. 113 (1973), permissible state intervention increases as pregnancy advances. Abortion cannot be proscribed in the first trimester, but may be regulated 
is reflected in other developments and could be extended to exclude the state from imposing its standards on other private medical decisions, including those involving life and death-thus establishing a kind of "right to die."218 A number of precedents, culminating in the recent and widely publicized case of In re Quinlan, ${ }^{219}$ illustrate the direction the law seems to be taking toward reserving to individuals the right to determine their own destinies when confronted with catastrophic disease.

Judicial decisions have allowed competent patients (or relatives acting on behalf of incompetents) to refuse some medical treatments, even where the result was likely to be fatal; many cases involve Jehovah's Witnesses' objections to blood transfusions. ${ }^{220}$ Courts have intervened mainly to protect minor children from being victimized by their parents' religious convictions, either where a child's own life is at stake or where the afflicted individual has minor dependents. ${ }^{21}$ In varying degrees, the rationale for self-determination reflects the free exercise clause, ${ }^{222}$ the right to privacy, ${ }^{223}$ and the wellestablished doctrine of informed consent to medical treatment. ${ }^{24}$ The free-

in the second trimester in the interest of safeguarding the mother and may be forbidden in the third trimester in the interest of protecting the viable fetus. Under Planned Parenthood of Cent. Mo. v. Danforth, 428 U.S. 52 (1976), states may limit the performance of abortions at any stage to licensed physicians only.

218. Although legally something of a misnomer, since there is no fundamental, unconditional right to die or to be killed, this expression is firmly rooted in popular consciousness. See, e.g., THE Dying Patient (O. Brim. H. Freeman, S. Levine, \& N. Scotch, eds. 1970) (overview with annotated bibliography); Fletcher, supra note 205. See also text accompanying note 195 supra.

219. 70 N.J. 10, 355 A.2d 647 (1976).

220. See, e.g., In re Brooks' Estate, 32 Ill. 2d 361, 205 N.E.2d 435 (1965) (court refused to order transfusion). But see, e.g., John F. Kennedy Memorial Hospital v. Heston, 58 N.J. 576,279 A.2d 670 (1970) (transfusion authorized). See also In re Quinlan, 70 N.J. 10, 39, 355 A.2d 647, 663 (1976). For general discussions, see R. VeAtch, supra note 162, at 116-63; Cantor, A Patient's Decision to Decline Life-Saving Medical Treatment: Bodily Integrity versus the Preservation of Life, 26 Rutgers L. Rev. 228, 228-36 (1973). Unless the medical provider counseling an undesired transfusion seeks court authorization, the unwilling patient may have little legal recourse. If the provider simply proceeds with treatment, the patient probably would not have time to seek advance judicial intervention to prevent it, and after-the-fact suit for battery or negligent failure to get informed consent is unsatisfactory. Not only is an action for monetary damages unlikely to assuage the perceived spiritual harm, but the factfinder is unlikely to make a significant award after setting off the value to the patient of the transfusion's presumedly lifesaving effects. In the latter respect, such suits are like those for "wrongful life" brought by plaintiffs claiming they would have been "better off" dead; courts have greeted these with little favor. E.g., Gleitman v. Cosgrove, 49 N.J. 22, 227 A.2d 689 (1967). See also Comment, Liability for Failure of Birth Control Methods, 76 Colum. L. Rev. 1187, 1187 n.4 (1976). Legal questions could arise of course over the patient's liability to pay the bill for the unwanted service.

221. See, e.g., State v. Perricone, 37 N.J. 463, 181 A.2d 751, cert. denied, 371 U.S. 890 (1962) (child); Application of the President and Directors of Georgetown College, 331 F.2d 1000 (D.C. Cir.), cert. denied, 377 U.S. 978 (1964) (mother of baby). See generally R. VEATch, supra note 162, at $123-36,155-61$.

222. See, e.g., Cantor, supra note 220, at 238-39; Note, Compulson Medical Treatment and the Free Exercise of Religion, 42 IND. L.J. 386 (1967).

223. See, e.g., Cantor, supra note 220 , at 239-42.

224. E.g., Erickson v. Dilgard, 44 Misc. 2d 27, 252 N.Y.S.2d 705 (Sup. C.. 1962); see generally Harper \& James, The Law of Torts $\$ 17.1$ (1956); Note, Restructuring Informed Consent: Legal 
dom thus guaranteed individuals to influence their own treatment, even to make what most people would regard as patently wrongheaded decisions with possibly fatal consequences, ${ }^{225}$ suggests that judges may be more respectful of patients' rights and more aware of the distorting influence of the lifesaving imperative than are more political institutions. ${ }^{226}$

Although legal doctrine can easily be found to support voluntary selfdetermination for competent adults, serious problems arise where a patient is unconscious, comatose, or otherwise incompetent to participate in decisions on catastrophic care. ${ }^{227}$ Traditionally, care for such patients has been informally determined by the victim's doctor, in consultation with the patient's family. The growing complexity of potential medical interventions and increased concern about possible legal liability has led to a search for a more formal solution.

The leading case involving an incompetent patient and involuntary cessation of treatment is that of Karen Quinlan, a young unmarried adult maintained in a "chronic persistent vegetative state" 228 through artificial life support. When her condition remained essentially hopeless after several months of treatment, her parents requested that such extraordinary measures be discontinued and released the medical providers from all liability. ${ }^{229}$ Her doctors resisted this choice, and her father applied to a New Jersey court to be named her guardian and given express judicial authorization to have disconnected the respirator maintaining her vital functions. ${ }^{230}$ The trial judge refused to intervene, saying Karen Quinlan was "alive," ${ }^{231}$ and that the "compelling state interest ... in preservation of life" and the "doctor's duty to provide lifegiving care" meant that "there is no constitutional right to die that can be asserted by a parent for his incompetent adult child."232

Therapy for the Doctor-Patient Relationship, 79 YALE L.J. 1533 (1970); Note, Informed Consent, supra note 193, at 1648: "The patient's right to an informed consent makes no sense without a right to an informed refusal." Constitutional notions of privacy and free exercise of religion may underlie the consent doctrine in this area. Id. at $1644-45 \& \mathrm{nn} .75-76$ : In re Quinlan, 70 N.J. 10, 39-40, 355 A.2d 647, 663 (1976) (apparently limited to terminal patients). In any case, all three rationales are similar in supporting individual self-determination against government intervention.

225. Cf. Application of the President \& Directors of Georgetown College, Inc., 331 F.2d 1000 , rehearing denied. 331 F.2d 1010 , cert. denied, 377 U.S. 978 (1964): "[T]he 'right to be let alone" [is] ... intended to include a great many foolish, unreasonable and even absurd ideas which do not conform, such as refusing medical treatment even at great risk." 331 F.2d at 1017 (Burger, J., dissenting).

226. Cf. In re Quinlan. 70 N.J. 10, 28-29. 355 A.2d 647.657 (1976) ("the supposed [medical] imperative to sustain life at all costs").

227. See generally R. VEATCH, supra note 162 , at 136-59.

228. In re Quinlan, 70 N.J. 10, 23-24, 355 A.2d 647, 654 (1976).

229. In re Quinlan, 137 N.J. Super. 227, 250, 348 A.2d 801, 813-14 (1975) (trial court).

230. 70 N.J. at $18,355 \mathrm{~A} .2 \mathrm{~d}$ at $65 \mathrm{l}$.

231. 137 N.J. Super. at 256,348 A.2d at 817 .

232. 137 N.J. Super. at 265-66, 348 A.2d at 882. The trial court concluded that the decision whether to continue care should be "left to the treating physician" as "a medical decision, not a judicial one." 137 N.J. Super. at 260,348 A.2d at 819 . Here, the attending physician had testified 
The Supreme Court of New Jersey reversed. Though Karen Quinlan was not dead, she could never hope to recover, and the state's interest in preserving her life was consequently attenuated. ${ }^{233}$ Her constitutional right of privacy was held "broad enough to encompass a patient's decision to decline medical treatment under certain circumstances," ${ }^{234}$ among them her irreversible condition, and could be exercised by her father as guardian. ${ }^{\mathbf{2 3 5}}$

The interest of physicians in practicing medicine according to professional medical standards was not directly assessed, but the patient's and her guardian's right to choose whether or not to accept treatment was held paramount; ${ }^{236}$ she (or her guardian) was entitled to select her doctors (and thus their style of practice). ${ }^{237}$ The court recognized that removal from the respirator would not conform to medical practice, standards, and traditions, but refused to be bound by a professional medical standard. ${ }^{238}$ Rather it undertook to establish a standard for involuntary cessation of life support that would be "responsive not only to concepts of medicine but also to the common moral judgment of the community at large." ${ }^{239}$ The proper rule of decision was not "life" or "death" as medically defined, ${ }^{240}$ but rather salvageability-"the prognosis as to the reasonable possibility of a return to cognitive and sapient life." ${ }^{241}$ Discontinuation of life support, even in the face of almost certain death, could not only be a rational choice but would also be the choice of an "overwhelming majority" of society. ${ }^{242}$

The Quinlan decision therefore allows treatment to be terminated with the consent of the patient's guardian where a patient is not medically salvageable,

that turning off the respirator would be a "substantial deviation from medical tradition," 137 N.J. Super. at 250, $348 \mathrm{~A} .2 \mathrm{~d}$ at 814 . The court concluded that, at least under these circumstances, discontinuing treatment would be homicide under the law of New Jersey. $137 \mathrm{~N}$.J. Super. at 262, 348 A.2d at 820 .

233. $70 \mathrm{~N} . \mathrm{J}$. at $41-42,355 \mathrm{~A} .2 \mathrm{~d}$ at 664 : In the continuum of life-sustaining treatments, "as the degree of bodily invasion increases and the prognosis dims . . there comes a point at which the individual's rights overcome the State interest [in preserving life]." See also notes $169-72$ supra and accompanying text. This view of the State interest may undercut the court seeming acceptance of (competent) terminally ill patients' unqualified right to refuse treament. 70 N.J. at $39-42.355$ A.2d at $663-64$.

234. $70 \mathrm{N.J}$. at $39-40,355 \mathrm{~A} .2 \mathrm{~d}$ at 663 .

235. 70 N.J. at $41-42.355$ A.2d at 664. The "circumstances" the court found relevant apparenty included its opinion that "the overwhelming majority" of society would also choose to cease life support. Id. In permitting refusal of treatment, the court did nol, however, substitute its judgment for that of the patient or guardian, as some courts have in compelling treatment. See sources cited note 220 supra.

236. 70 N.J. at $39-41,355$ A.2d at $663-64$.

237. $70 \mathrm{~N}$.J. at $54,355 \mathrm{~A} .2 \mathrm{~d}$ at 671

238. $70 \mathrm{~N} . J$. at $25-26,44-47,355 \mathrm{~A} .2 \mathrm{~d}$ at $655,666-67$.

239. $70 \mathrm{~N} . \mathrm{J}$. at $44,355 \mathrm{~A} .2 \mathrm{~d}$ at 665 . Acknowledging that the dilemma was usually resolved in a low-visibility decision by family and physician without judicial involvement, the court argued that selting the standard was a "nondelegable judicial responsibility." Id.

240. Id.

241. 70 N.J. at $50-5 \mathbf{i}, 355$ A.2d at 669 .

242. See note 235 supra. 
provided this medical judgment is affirmed by a hospital ethics committee or similar body. ${ }^{243}$ The principal decision is thus firmly lodged within the "patient-doctor-family relationship," ${ }^{244}$ with the physician providing important information and in a sense validating the treatment choice. ${ }^{245}$ The hospital committee review diffuses professional responsibility, easing pressure on individual doctors, who may face conflicts of interests. ${ }^{246}$ Yet at the same time it

243. $70 \mathrm{~N}$.J. at $54-55,355 \mathrm{~A} .2 \mathrm{~d}$ at 671-72. The court drew the idea for a committee from Teel. The Phrsician's Dilemma: A Doctor's View: What the Law Should Be, 27 BAYLOR L. Rev. 6, 8-9 (1975). Cf., e.g., KaTz \& CAPron, supra note 93, at 222-35 ("Institutional Advisory Committee"); J. Wilson. Death b y Decision 176-80 (1975) ("committee of medical and non-medical specialists"). Few institutions now have such committees. N.Y. Times, June 27, 1976, § 1, at 36, col. 3. See also Fried, Terminating Life Support: Out of the Closet!, 295 NEw Eng. J. MED. 390 (1976).

244. $70 \mathrm{~N}$.J. at $50-51,355 \mathrm{~A} .2 \mathrm{~d}$ at 669.

245. The Supreme Court has emphasized the importance of the "[t]he participation by the attending physician in the abortion decision, and his responsibility in that decision ...." Planned Parenthood of Cent. Mo. v. Danforth, 428 U.S. 52, 61 (1976) (discussing Roe. v. Wade, 410 U.S. 113 (1973)). See also id. at 89-92 (Stewart, J., concurring) indicating concern for the "chilling" of a physicians's professional judgment and emphasizing the importance of minors' seeking nonbinding counsel prior to undergoing an abortion. The device adopted in Quinlan, allowing a parental guardian to choose the attending physicians, protects the patient's right to choose from the dominance of any particular doctor but retains the physicians validating and legitimating role.

It is arguable that the requirement for approval by a hospital committee rums afoul of the standard enunciated in Doe v. Bolton. 410 L.S. 179 (1973). a companion abortion case to Roe $\%$. Wade. The Georgia statute examined in Bolton had defined circumstances under which abortions would be permitted. including a requirement-held unconstitutional-that a hospital abortion committee approve abortions in advance. However, once Roe made it clear that a woman has a right to receive an abortion in accordance with her physician's best medical judgment, the reviewing committee became "basically redundant," since the comparatively simple medical judgment could be made by the physician without any assistance from the committee. 410 U.S. at 197. In abortion cases, the woman is presumably capable of safeguarding her own interests, and under Roe the states interest in the potential life of the fetus is not compelling until the point of viability; so the existence of the abortion review committee is overly restrictive of the woman's rights.

B: contrast, a comatose patient like Karen Quinlan cannot exercise her own constitutional rights, and whether a guardian should be allowed to do so hinges on whether there is a "reasonable possibility" that the patient will regain cognition. $70 \mathrm{~N} . \mathrm{J}$. at $55,355 \mathrm{~A} .2 \mathrm{~d}$ at 672 . This medical decision consequently takes on considerably more constitutional significance than physician judgments in abortion cases. The hospital review committee contemplated in Quinlan is expected to provide significant professional consultation to the attending physician in making this difficult and important determination. Moreover. in cases like Quinlan the states interest in preserving life is far stronger than in the abortion context, diminishing only where it appears that the patient cannot reasonably be expected to regain a "cognitive, sapient state." Id. Having that determination made by a physician and validated by a consultative hospital committee therefore rejects a legitimate state concern. It is not the redundant and unduly restrictive review for abortions struck down in Bolton. Presumably, however, under Quinlan, just as the guardian can choose the attending physician, the guardian or physician could shift a comatose patient from a hospital whose reviewing commituee declined to approve cessation of heroic treatment. Otherwise. the panel would have a veto power akin to the one found objectionable in the Planned Parenthood case, supra.

246. The New Jersey court was very concerned about the potential conflict a physician faces in serving his patient yet protecting himself from malpractice or criminal liability. 70 N.J. at 49 , 355 A.2d at 668. But $f$. Burt, supra note 157 (maintaining potential physician criminal liability for withholding treatment from anomalous newborns serves valid function of restraining abuse). Other possible sources of conflict include the desire to obtain transplantable organs, see note 161 
provides a check on private decisions, ${ }^{247}$ thus perhaps allowing government to remain further in the background than it otherwise could.

The Quinlan court carefully kept the state at a distance in this process, even while establishing the salvageability standard by judicial decision. It emphasized that courts are ordinarily "inappropriate" for making the actual decisions $^{248}$ and refused to grant express permission for shutting down the respirator. ${ }^{249}$ The court also removed all civil or criminal liability for private decisions made under the Quinlan circumstances, whether by family, guardian, physician, or hospital. ${ }^{250}$

supra and accompanying text, the desire to save treatment costs (where doctors or hospital bear some of the expenses, as in an HMO or for charity patients), and the desire to transfer scarce medical resources to the use of another patient deemed more needy.

247. $70 \mathrm{~N} . \mathrm{J}$. at $50.355 \mathrm{~A} .2 \mathrm{~d}$ at 669 : "Moreover, such a system would be protective to the hospital as well as the doctor in screening out, so to speak, a case which might be contaminated by less than worthy motivations of family or physician." The danger, of course, is that an occasional physician might make himself available as a "gun for hire" to families less conscientious than the Quinlans and more interested in saving treatment costs or hastening their inheritance from an elderly relative. Yet medical custom and practice could supply checks on abuses, since the constitutional right of privacy could be held to shield from criminal prosecution only actions in the mainstream of medical tradition. For an argument that formalization of medical standards would be desirable, particularly in clarifying the physician's duty in counselling families and his duty not to implement purely selfish choices, see Robertson, supra note 204, at 266-69.

Concern may be strongest in the case of defective newborns and their families. Deciding what care should be provided to such deformed infants (including choices for involuntary cessation of treatment like that of Quinlan) is particularly troublesome and especially poignan because they have had no chance for life and have alwavs been incapable of voluntary consent. See. e.g. . Duff \& Campbell, Moral and Ethical Dilemmas in the Special-Care Nursery. $289 \mathrm{NEw}$ ENG. J. MED. 890 (1973); Hevmann \& Holtz, supra note 163; Nolan-Halev, Defective Children. Their Parents, and the Death Decision, 4 J. LEgal MED., Jan. 1976. at 9: Robertson, supra note 204. Some decisionmaking proxy is essential. There is evidence that in practice a Quimlan-like standard of meaningful life is applied by some parents and doctors, see D. Crane, The Sanctity of Social Life: Physicians' Treatment of Critically Ill Patients 4-6, 49-52, $199-200$ (1975); Duff \& Campbell, supra, but both professional and legal clarification of parents' and doctors' responsibilities may be warranted. But see Burt, supra note $15 \%$.

It is hard. however. to envision a better locus for such agonizing decisions than the family in conjunction with their medical providers, and the scope of the right of privacy should be considered in this context where parents have traditionally exercised their authority. See. e.g. . Bennet, Allocation of Child Medical Care Decisionmaking Authority: A Suggested Interest Analysis, 62 VA. L.. Rev. 285, 285-88, $311-17$ (1976). Whether family-doctor decisions are to be protected by a familial right to privacy-similar to the "marital privacy" of Griswold v. Comnecticut, 281 U.S. 479 (1965)-remains to be decided. See generally Moore v. City of East Cleveland, 45 U.S.L.W. 4550 (U.S. May 31, 1977); Carey v. Population Services, Int'l, 45 U.S.L.W. 4601 (U.S. June 9, 1977). Professor Tribe has upheld the family's right to choose to have abortions-a somewhat analogous decision-despite the family's self-interest and lack of medical expertise; he notes "how the family's claims in this area are rooted in a constitutionally recognized associational integrity." Tribe, supra note 207, at 51 . The Quinlan approach of protecting guardian and doctor as necessary implementors of the patient's right-of-privacy choice, $70 \mathrm{~N}$.J. at $52,355 \mathrm{~A} .2 \mathrm{~d}$ at 670 , is less likely to be acceptable in the case of newborns who have never exercised conscious choice.

248. $70 \mathrm{~N} . J$. at $50,355 \mathrm{~A} .2 \mathrm{~d}$ at 669 . It should be noted, however, that the cited weaknesses of judicial decisionmaking were not those given here, but rather "gratuitous encroachment upon the medical profession's field of competence" and "impossibly cumbersome" procedures. $I d$.

249. $70 \mathrm{~N}$.J. at $34-35,355 \mathrm{~A} .2 \mathrm{~d}$ at 660 .

250. $70 \mathrm{~N}$.J. at 54-55, $355 \mathrm{~A} .2 \mathrm{~d}$ at $67 \mathrm{l}$. 
The most notable thing about the Quinlan case is neither its result, for similar results are routinely achieved without judicial intervention, nor its standard, since lack of human potential is in fact the standard applied by many or most practicing physicians. ${ }^{251}$ Rather it is the new actor in the decision, the ethics committee, and the new safeguard for decisionmakers-substantial immunity from civil and criminal liability in deference to a patient's broad right of privacy. As an "a-responsible" agency, the committee can help make tragic choices without clearly articulating its rationale ${ }^{252}$ and thus help preserve a large and important private realm of choice in a very private and sensitive area. There is, however, some danger that the committee role will be overextended. Committee concurrence should probably be required only in involuntary cases, lest it unduly bureaucratize the straightforward voluntary choices of competent patients, ${ }^{253}$ although such a group might provide useful aid for difficult decisions on competency itself and on the voluntariness of consent. ${ }^{254}$

Quinlan is not definitive. The exact nature and extent of the protected zone of privacy remain to be resolved: ${ }^{255}$ Many practical questions about the

251. See generally D. Crane, supra note 247. See also In re Quinlan, 70 N.J. 10, 28-29, 47-48. 355 A.2d 647, 657,667 (1976): Fried. supra note 243; Levine. Disconnection: The Clinician's Vieu. Hastings Ctr. ReP., Feb. 1976. at 11.

252. See notes 89, 90 supra and accompanying text. Cf. Katz \& Capron, supra note 93, at 189-92 (discussion of the problems of explicit collective decisions and the potential advantages of not articulating specific value choices). For critical views of such use of ethics committees, see $R$. Veatch, supra note 162, at 173-76; In re Quimlan: Legal Comfort for Doctors, Hastings CTR. ReP., June 1976, at $29,30-31$.

253. But of. J. WILSON, supra note 243 , at 173-74:

Patients who are suffering and dying usually cannot make responsible medical decisions on their own. In the majority of cases. the responsibility for their care rests entirely on their families or their doctors. In a complex and mobile society, however, familial relationships are often tenuous and undependable. Furthermore, because the practice of medicine is highly specialized, the doctor-patient relationship tends to be technical and impersonal.

Wilson therefore supports committee decisions under established guidelines. Id. at 176-85. See also D. Crane, supra note 247 , at 47-48, 204-06

254. Cf. note 245 supra (validating role of individual physician).

255. The right of privacy is not absolute and may be outweighed by "compelling" state interests. See, e.g. Roe v. Wade, 410 U.S. 113, 153-54 (1973). The line drawn in Quinlan is unclear. Compare $70 \mathrm{~N} . \mathrm{J}$. at 39-42, 355 A.2d at 663-64 (1976) (only the invasive nature of life support and Karen Quinlan's irreversibly comatose condition allow termination of life support) with $70 \mathrm{~N}$.J. at 54 n. 10,355 A.2d at 671 n. 10 (reasoning may apply to "terminal" patients without "hopeless loss of cognitive or sapient life").

Nor did the court clarify just what treatments could be witheld, simply saying, "the present life-support system may be withdrawn. . ." $70 \mathrm{~N} . J$. at 54, $355 \mathrm{~A} .2 \mathrm{~d}$ at 671. Mr. Quinlan chose to withdraw only the "extraordinary" care of the respirator, and his daughter was successfully "weaned" from it. not dying as expected. Transferred to a nursing home under a new physician's supervision, she continues to receive "ordinary" care. including life-supporting intravenous feedings and antibiotics-as her family wished. N.Y. Times, June 27, 1976, at 1, col. 6. See also Battelle, 'Let Me Sleep: The Story of Karen Ann Quimlan, Ladies Home J. Sept. 1976, at 69. Query whether Quinlan allows the Quinlans to change their minds after even more time elapses and legally withdraw more "ordinary" forms of medical life-support. 
role of the committee and patients' changing of physicians can be expected to arise, though these may not require judicial intervention. Further litigation of this type, however, seems inevitable, ${ }^{256}$ given the continuing growth of government and insurance funding, as well as the technological ability to sustain life through medical intervention. ${ }^{257}$

Judicial delineation of a sphere of private responsibility for medical treatment at the end of life can foster civil harmony and individual moral responsibility. Some appear to believe that all such judgments must be societal ones and that individuals are ill-equipped to accept responsibility for such choices, requiring instead the state's assumption of ultimate responsibility or at least its explicit ratification of the choices made. While some protections are clearly necessary in cases of involuntary cessation of treatment, we believe that other and better moral supports are available, and that people should be encouraged to supply their own or to seek counsel. In Quinlan, for example, the doctor, in conjunction with the hospital committee, serves not only as technical advisor but also as counselor and moral agent. Physicians should fill this role to the extent they are able, but not to the exclusion of other individual helpers and institutional supports. ${ }^{258}$

An additional benefit likely to derive from leaving many life-and-death decisions to private individuals in consultation with physicians is an economic one, which many would perhaps prefer to leave unmentioned. ${ }^{259}$ In judging the desirability of heroic life-sustaining efforts, private decisionmakers may well be less attached to treatment at any cost than would be publicly account-

256. The Qumlan court recognized this, $70 \mathrm{NJ}$. at $55,355 \mathrm{~A} .2 \mathrm{~d}$ at 672 , even while hoping that most determinations could be made extrajudicially. Since Quinlan, the Supreme Court of Massachusetts has approved withholding a life-prolonging but difficult treatment of leukemia in a sixty-seven-year-old retarded state patient with a mental age of three. See MEdiCAL WorLd News, Aug. 9, 1976, at 8; Boston Globe, July 13, 1976, at 1, col. 4.

257. A different and far more serious complication is introduced by another form of the treatment dilemma in critically ill or terminal patients-positive action by doctors or others to hasten death as a termination of incurable suffering. This is called "active" euthanasia, e.g., C. Triche \& D. Triche. The Euthanasia Controversi' 1812-1974, A Bibliography with select Annotations v-vi (1975); D. Crane, supra note 247, at 67, and is far more controversial than the "passive" cessation of artificial life support at issue in Quinlan and similar cases. Some commentators, however, feel the active-passive dichotomy is more a matter of degrce than of kind, is difficult to apply in practice, and is a thin theoretical reed to support a major moral differentiation. See, e.g. Williams, supra note 204, at 182-83; Note, Informed Consent, sufra note 193. at 1650 \& n.97. But see, e.g., D. Maguire, supra note 201, at 43-47; Survey Takers Active on Euthanasia Question, Hastings Ctr. ReP. Aug. 1976, at 2. The debate over enuthanasia of all kinds has long raged, see, e.g., C. Triche \& D. Triche, supra, and this note is meant to contribute only the observation that the Quinlan right of privacy is relevant to the issue and that its application will ultimately have to be considered.

258. Cf. Planned Parenthood of Cent. Mo. v. Danforth, 428 U.S. 52, 91 \& n.2 (1976) (Stewart, $\mathrm{J}$, concurring) (physician is often an inadequate substitute for the counsel of parents of pregnant minors desiring abortions).

259. Neither Quinlan court mentioned the cost of her hospital care, reported to be $\$ 450$ a day, Am. Medical News, Nov. 3, 1975, at 9, col. 1, and borne primarily by the state of New Jersey through Medicaid, Battelle, supra note 255, at 76. 
able decisionmakers in a political, legalistic environment. Most people are probably pleased that their government is constitutionally (in the generic even more than the legal sense) unable to take direct cost-control measures to curb the treatment of life-threatening illness. One might hope, however, that, where government is congenitally incapable of acting, it can find ways of locating decisionmaking authority elsewhere in order to achieve humane treatment, to improve the allocation of resources, and to advance the sum total of human welfare. This section has considered some ways to accomplish this through legal doctrines which both shield individuals from state interference and shield the state from direct responsibilities which it is not well equipped to shoulder. The remainder of the article considers other such methods.

$\mathrm{V}$

Structuring Financing Mechanisms to Influence Private Choices

Leaving troublesome questions about medical care at the end of life largely to private choice should reduce some overspending prompted by the lifesaving imperative or the threat of legal sanctions (as well as yielding other benefits in a heterogeneous, individualistic society), but it will not obviate the cost-containment problem generally. Open-ended, almost all-inclusive catastrophic disease insurance will still invite individuals and physicians to pay insufficient attention to economic constraints in their decisions. Our inquiry here is therefore whether, in designing financial protection against catastrophic costs, government can legitimately take steps to impose on the individual decisionmakers some of the economic costs of their lifesaving efforts, thereby requiring individuals, families, and doctors to consider economic trade-offs. The approaches suggested here are intended to allow government to help protect individuals against undue financial hardship from a health calamity while at the same time limiting the distorting impact of the lifesaving imperative and increasing decisionmakers' cost consciousness. The broader goal is to help individuals and society cope more effectively with the reality of inevitable death and suffering without holding their government somehow to blame.

\section{A. Cost-Sharing Possibilities}

Cost sharing through coinsurance, copayments, and deductibles is widely, albeit not universally, accepted as a legitimate means of curbing utilization of health services, though such price rationing is regarded as less appropriate for low-income people, who may be induced to neglect basic health needs. ${ }^{260}$

260. See generally C. Phelps \& J. Newhouse, Coinsurance and the Demand for Medical Services (Rand Report No. R-964-OEO/NC, April 1973). Some observers object that even nonpoor insureds do not respond as intended to cost-sharing schemes. See. e.g., Ball, Response [to Prof. Schelling] in Institute of Medicine, National Academy of Sciences, Implications of 
Possibly an acceptable cost-sharing system could be designed along the following lines: Cost sharing might cease once a certain level of costs had been incurred, so that care would be wholly at public expense for a considerable while thereafter. But another breakpoint might occur later on, after which a not insignificant cost-sharing obligation would again apply. The entitlement to such a fixed amount of care free of cost sharing might be deemed a sufficient public investment without a private commitment. Moreover, the possibility of its exhaustion might induce providers and families to count costs from the beginning in anticipation of surpassing the initial allotment.

Government's obligation toward any given patient might be limited further by setting a dollar lifetime maximum beyond which insurance would cease to pay anything at all. ${ }^{261}$ Providing for automatic restoration of exhausted benefits at some constant annual rate would allow expended benefits to be earned back in periods of good health and would prevent the lifetime maximum from being depleted by a series of small expenditures. Another possibility that has been suggested is that any public insurance ceiling could decline over a lifetime ${ }^{\mathbf{2 6}}$ beginning at a certain age and disappearing at a specified rate per year thereafter. These ideas merely illustrate the many possibilities. The design of a lifetime insurance limit could aim at securing some impact on private decisions and advancing relevant distinctions about what society is willing to pay for. ${ }^{263}$

The justice of imposing some of the costs of catastrophic illness on the sick is a matter which can be debated only inconclusively. Arguments against cost sharing are 1) that, in many cases at least, the hazard insured against is grave and results from a random event and 2) that the potential size of patients' outlays can be extremely burdensome, thereby defeating the very purpose of insurance. Yet there is considerable evidence that many catastrophic diseases are not totally fortuitous but reflect choices of lifestyle and unhealthful behavior which the society might not wish to prohibit but which it might prefer

Guaranteeing Medical Care 39 (J. Perpich ed. 1975) (half of Medicare beneficiaries buy supplementary insurance to reduce cost sharing).

261. This is the approach of the Federal Employees Health Benefits Act plans (high option), 1 A.D. Little, supra note 14 , at $4-6$; it is widely conceded, however, that a claimant can achieve additional benefits by switching plans as he nears the lifetime ceiling. Id.

262. See Lachs, Questions of Life and Death, Wall St. J., Mar. 31, 1976, at 12, col. 4. Avoiding unfairness in designing such a scheme is a challenge, particularly at the boundaries between amounts of benefits. See also note 263 infra.

263. For example, benefits might be set to go up or down with age, as suggested by some research on "willingness to pay" or "human capital" approaches to valuing lives economically. See Acton, Measuring the Monetary Value of Lifesaining Programs, 40 Law \& Contemp. Prob. 46 (1976). Of course, age would not be the only relevant factor. See, e.g., Zeckhauser \& Shepard, Where Now for Saining Lifes? 40 Law \& Contemp. Prob. 5 (1976) ("quality-adjusted life years"). The egalitarian ethic and constitutional constraints would limit the policy-making applications of such research on the economic evaluation of human lives, and no serious legislative proposal has yet suggested variable benefits along such lines. But cf. Lachs, note 262 supra (informational proposal). 
not to subsidize. ${ }^{264}$ In addition, many steps in the treatment process itself might be of such little benefit as to be of relatively low priority compared with other uses for scarce government resources; they might more appropriately be paid for privately-or omitted altogether if private resources have better uses or are not available. ${ }^{265}$ Moreover, individuals committed to unconstrained financial commitments to all lifesaving as a moral imperative may not be entitled to have their preferences supported involuntarily by persons who are not like-minded.

An arrangement forcing individuals and families to bear a share of costs undeniably makes wealth a potential factor in the outcome. A partial solution to the justice questions thus posed would be to make sure that supplemental insurance coverage-over and above that mandated by government-was available to those who wished to purchase it at an actuarially fair price. ${ }^{266}$ The availability of supplementary insurance would not of course solve the problem of uninsurables or the poor. Nor would it allow society, or providers acting in society's behalf, to be too cold-blooded toward those who, having elected not to procure such insurance, live, like Faust, to regret their decision. Still, if a decent level of protection has been provided, the state's fundamental responsibility may be deemed discharged by the mandated coverage and by the outlay already made. ${ }^{267}$

It is important to observe that exhaustion of a patient's benefits or his inability to meet a cost-sharing obligation would not automatically be fatal, both because not all catastrophic illnesses threaten imminent death and because providers would frequently continue to take care of many such patients without charge, much as they do now. Indeed, preservation of the financial ability of providers to furnish some uncompensated services would seem de-

264. See, e.g., V. Fuchs, supra note 11, at 30-55; Knowles, The Responsibility of the Individual, 106 Daedalus 57 (Winter, 1977); Vaupel, Early Death: An American Tragedy, 40 Law \& Contemp. Prob. _- (1976); Veatch, Who Should Pay for Smoker's Medical Care? Hastings Ctr. ReP., Nov. 1974 , at 4 .

265. Long-term care provides perhaps the most dramatic example of this point. Society might reasonably conclude, especially since so much of the care is expensive, but nonlifesaving and only semi-medical, that family resources should to a substantial degree share long-term care costs with a government scheme. If a program defines "catastrophic" coverage solely on the basis of medical costs incurred by a beneficiary, much of its outlay can be expected to be for long-tern care for people with chronic conditions. See generally note 2 supra.

266. Within the limits of practicality, insurance companies can design coverage to reflect the varying risks of different groups of similarly situated people. One can imagine smokers paying more than nonsmokers for health insurance and an insurance market in which subscribers to the right-to-life-at-any-price philosophy would face higher premiums to cover costs of elaborate heroic treatment. Insurers should be encouraged to offer numerous packages of insurance and to categorize insureds in whatever way they can. A program of government loans or income replacement, discussed in Section V.B. infra, could also help mitigate the effect of wealth or ability to make cost-sharing payments.

267. Cf. Fried, supra note 5 ("decent minimum"); Rosenthal, supra note 5 (floor); Michelman, On Protecting the Poor. Through the Fourteenth Amendment, 83 Harv. L. REv. 7 (1969) (basic level of protection). 
sirable as a means of softening the impact of benefit limits imposed by government in a catastrophic insurance plan. ${ }^{268}$ Moreover, providers, in rationing their limited discretionary funds, might engage in precisely the kind of benefit-cost balancing that is so difficult to achieve in more formal mechanisms, choosing perhaps to serve those patients who could be saved most cheaply or those who could be restored to the most useful existence or to the most satisfactory quality of life. This reliance on providers, where benefits are exhausted, could be an important buffer against pressures on government to expend unlimited sums to save a single (identified) human life, although this strategy might risk offending commonly held notions of equity.

\section{B. Catastrophic Disease Protection Through Income Replacement}

In order for cost sharing to serve as an effective constraint, improving the allocation of resources, the patient's obligation must be more than nominal; yet in catastrophic expenditure ranges even a moderate cost-sharing requirement could be excessively burdensome for many people. It might be possible, however, to design a system of income support payments triggered by the onset of a catastrophic illness which not only would soften the economic hardship of substantial cost-sharing obligations but at the same time would spare families at least some of the hardship flowing from the loss of the income or services of the family member affected. Such a plan could be a considerable improvement over the pure medical insurance model being touted to deal with catastrophic disease. Health insurance alone does both too much and too little, covering too much of the medical costs to induce economy but providing too little protection against the disruption of family finances.

So far, the debate about government financing for catastrophic illness has not adequately recognized the necessity for both promoting cost consciousness and preventing financial hardship, and medical payment plans which seem to solve one problem necessarily exacerbate the other. But both problems might be dealt with by shifting the primary focus of governmental intervention away from direct payment of catastrophic medical costs, providing instead specific indemnity payments for victims of catastrophic illnesses. ${ }^{269}$ Payments would

268. This admittedly contemplates a form of internal subsidization, but is arguably warranted in this limited class of cases. See generally note 17 supra. This provision of some slack in the system has been called "ethical inefficiency"-allowing the special humane appeal of some cases to override more general benefit-cost calculations. Neuhauser \& Lewicki, National Health Insurance and the Sixth Stool Guaiac, 2 Policy Analysis 175, 494-95 (1976).

269. Although some appear to believe that any government role should be limited to underwriting an indemnity form of insurance, Newhouse \& Taylor, How Shall We Pay for Hospital Care?, 23 Pub. Interest 78, 86-92 (1971), that approach would not solve the problem of the improvident "free rider" who chose not to insure himself against major medical risks. See text accompanying notes $38 \& 39$ supra. Some government action to see that insurance against catastrophic illness is provided for also seems indicated. See Blumstein \& Zubkoff, supra note 11, at 423-25. It should be noted, however, that the "free rider" rationale for government intervention does not necessarily require direct public support, except perhaps for the poor. A "hard-nosed" approach 
be designed to help I) replace income or household services lost during the period of disability and 2) meet substantial cost-sharing obligations under an underlying insurance policy covering catastrophic medical expenses, the purchase of which would be a prerequisite for participation. ${ }^{271}$

Not only would a program of indemnity payments provide important income support for individuals or families in time of need, but it would also serve to disassociate government from decisions on the actual provision of medical care, which would be left to patients, families, insurers, and providers. A high degree of cost consciousness would be preserved, since patients and families would themselves face part of the costs of care and would have in hand sufficient funds to be able to pay them. ${ }^{2 i 1}$ The necessity for allocating the available resources among all familial needs would provide significant incentives to spend wisely, selecting lower-cost institutions and doctors willing to weigh the costs of alternative treatments. ${ }^{2 i 2}$ No longer cast in the role of

could simply require the nonpoor to self-insure just as auto insurance (both liability and nonfault) is now required. Id. at 423. The indemnity proposal reflects a more active, beneficent government role and a sense that the lifesaving imperative might elicit public charity even for an illegally uninsured victim of catastrophic disease (or auto accident).

Some observers question whether indemnity payments can effectively create cost-containment incentives. E.g., Davis, Comment [to Prof. Schelling], in Institute of Medicine, National Academy of Sciences, Implications of Guaranteeing Medical Care 53, 54 (J. Perpich ed. 1975): “[G]reater reliance on indemnity insurance... makes little sense when applied to a mar. ket where any guaranteed payment for a service quickly becomes a floor on which to apply additional patient charges." Accord Ball, supra note 260, at 43. The proposed income replacement plan would differ from many indemnity plans in paying indemnities for an entire episode of disease rather than for given services or courses of treatment.

270. The underlying insurance could be either public or private and could be either mandatory or merely strongly induced by making its prior purchase a condition of receiving indemnity payments-depending on the degree of coercion and government involvement desired. (The goal of distancing government from medical decisions would obviously be better met by private underwriting. ) Standards for acceptable basic catastrophic coverage should be set in any event, and government intervention to foster an active private market would also be appropriate. Presumably individuals or families could buy more extensive coverage privately if they chose not to rely solely on the indemnity program to meet cost-sharing requirements. Further protection could possibly be provided by a system of government loans if this could be achieved without undercutting the income replacement program.

271. The income replacement concept does contemplate conflict between patients' medical needs and their (and their families) other needs. Such conflicts exist now in case of serious illness, see note 247 supra. and supplementary funds might as often ease them as heighten them. Thus, potential conflicts, while troubling, seem an acceptable price of effective cost control, especially since medical providers may well serve as patient advocates. The opposite danger may be greater-that patients and families will feel forced to spend all available funds on medical care, despite the income replacement aspect of the plan. At a minimum, providers should probably be forbidden routinely to attach, or require assignment of, a patient's indemnity. See also note 280 infra.

The approach proposed here would also aid cost control through its emphasis on income support payments, which can be determined in advance, rather than on medical or service-oriented payments, which cannot be easily contained.

272. This system might allow frugal recipients to "profit" from an illness, just as a welfare family now might be able to save some current benefits for future use. Neither result should be troubling. 
payer for any and all catastrophic medical care, government could avoid the thorny symbolic issues presented by tragic choices, leaving those matters in private hands. Rather than having to say "no" in a life-or-death case-or having to say "yes" mainly for symbolic reasons regardless of the cost of lifesaving efforts-government would be able to serve simply as the supporter of the family in its time of need, leaving spending decisions to the recipients' discretion. ${ }^{273}$ Historically, medical support programs have tended to follow and to be built upon government's income maintenance initiatives. ${ }^{274}$ Moreover, a major reason that coverage for catastrophic illness has become a pressing public policy issue is the threat of family bankruptcy, against which medical coverage alone is insufficient protection.

The practical problems of developing such a program of indemnity payments are considerable, since the amount of income support appropriate to individual cases would vary widely and there would be danger that some families would receive payments inadequate to their needs while others would enjoy windfalls. For this reason, the program's coverage would have to be highly categorical, and there would still be considerable arbitrariness at the margins. Payments would be governed by a combination of circumstances affecting probable need, including the anticipated extent of medical expenditures $^{275}$ according to the nature of the illness or condition ${ }^{276}$ and the

273. G.I. benefits for education are analogous; there, government pavs veterans for attendance but does not come between student and school. This allows veterans, among other things, to attend even church-affiliated schools without running afoul of the constitutional separation of church and state; it also minimizes government involvement in educational institutions. The discretion to be allowed indemnity recipients is also similar to that accorded beneficiaries of unemployment compensation and other such programs.

274. Income support programs have traditionally preceded categorical medical payment programs and built upon their definitions of eligibility. Thus, Medicare and Medicaid added new medical benefits for people already eligible for income support. Similarly, 1972 amendments added Medicare coverage to previous disability benefits. See generally Dixon, The Welfare State and Mass Justice: A Warning from the Social Security Disability Program, 1972 Duke L.J. 781; Liebnan, The Definition of Disability in Social Security and Supplemental Security Income: Drazing the Bounds of Social Welfare Estates, $89 \mathrm{HARv}$. L. REv. 833 (1976). Adding medical insurance benefits to unemployment insurance was also suggested during the recent recession. This prior pattern of medical benefits' following a previously determined program of income support has somehow been lost in the debate about catastrophic illness and costs. Other nations have not ignored the importance of income replacement as a part of a social insurance program. See. e.g., Reinhardt, Health Cost and Expenditures in the Federal Republic of Germany and the United States, in International Health Costs and Expenditures 249, 262-73 (Teh-Wei Hu ed. 1976) (Fogarty Int'l Ctr. for Advanced Study in the Health Sciences).

275. Whereas total expenditures are the sole trigger of catastrophic coverage in current proposals, notably the Long-Ribicoff bill, see section II.B. supra, for this proposal cost is only one of several considerations. Expenditures could include either total medical expenses or only out-ofpocket ones, and the program might or might not consider only expenditures over a certain proportion of patient or family income or resources. If payments were to be made as a lump sum, see note 279 infra, anticipated future expenditures would have to be computed.

276. Not all diseases or treatments need be covered; for example. plastic surgery might be deemed unworthy even if catastrophically expensive. Diseases threatening imminent death without care are probably the strongest candidates. A 1969 DHEW task force suggested distinguish- 
degree and effect of resulting disability. ${ }^{277}$ Ease of administration might be found to require creating an eligibility list of covered events the occurrence of which (or their equivalent) would trigger the indemnity payments. ${ }^{278}$ Benefits might be either lump-sum, periodic, or a modification of the two, depending upon circumstances. ${ }^{279}$ Payments would thus need to be related to both goals-income replacement and support for a portion of catastrophic medical expenses not covered under the prerequisite insurance policy. ${ }^{280}$

In view of its obvious complexities, this idea is offered only tentatively. ${ }^{281}$

ing between life-threatening illnesses and non-fatal chronic illnesses which may nonetheless have costly therapeutic regimens. See Catastrophic Illnesses and Costs, supra note 1. But it would seem unwise to focus exclusively on life-and-death cases; the lifesaving imperative should be skirted in a program designed to prevent family bankruptcy. Covered diseases generally should be those most apt to elicit public charity in the absence of a catastrophic program, in keeping with the goal of dealing with the "free rider" problem. This plan would not define illnesses as "catastrophic" solely by their costs or by listing specific conditions, but by a combination of the two approaches. See notes 1 and 2 supra and accompanying text. (There may, however, be resistance to coverage by disease or condition. See notes 1,28 supra.)

277. Some diseases that are catastrophically expensive may nonetheless with treatment constitute manageable disability-hemophilia, for example-so that some criteria for granting income replacements are needed. One standard might be eligibility for benefits under the current disability program of the Social Security Act. The existing program could perhaps itself serve as the vehicle to cope with the problem of catastrophic illness generally, as it has been modified to serve victims of end-stage renal disease, though the current eligibility standards are probably too stringent. See 42 U.S.C. 423(d)(1), (d)(2)(A) (1970), 20 C.F.R. $\S \S 404.1501-39$ (1976). See generall Liebman, supra note 274 , at $847-55$. The proposed plan's emphasis on disability would establish for government a functional approach towards health, stressing its instrumental nature. See Blumstein \& Zubkoff, supra note 11, at 398-99, 423.

278. The approach of the current disability program might be followed: Claimants qualify by showing (1) listed illness, (2) substantially equivalent illness, or (3) actual medical disability. 42 U.S.C. $\$ 423(\mathrm{~d})$ (1970); 20 C.F.R. $\$$ 404.1502, 404.1506 (1976). The "equivalent" approach would mitigate the potential arbitrariness of an exclusive listing of covered events.

279. The typical pattern of expenditures for different illnesses and conditions would be the important factor in fixing appropriate payment schedules. For example, a chronic patient requiring considerable ongoing care might best receive periodic payments.

280. Determining the appropriate payments will be a difficult but important political task based on perceptions of the needs of individuals and families with debilitating illness. The medical portion of the indemnity would be related to the typical expense of the event. On the one hand, equal payments to all would leave some recipients still necessitous, while others would realize windfall "profits" from their illness. On the other hand, completely individualized payments would merely convert the program into a cost-plus supplemental insurance scheme and complicate administration as well. Determining the income support portion would be difficult. It could be a standard amount, to ease administration and sidestep the problem of imputing income, especially for lost household services. Alternatively, it could be tailored to individual circumstances and collateral sources.

Despite the bipartite nature of computing an award to cover both medical and income aspects, a joint, undifferentiated payment should be made; the essence of the program is to leave the ultimate allocation of resources to recipients. For the same reason, changes in award schedules should not be made in lockstep with medical inflation. To be effective, the program must be perceived as support for beneficiaries and families, not as an automatically enlarged hunting ground for medical providers. See also note 271 supra.

281. An alternative approach to that presented in the text would simply tie indemnity eligibility to the onset of payments under an approved catastrophic insurance policy. Whether to cover only expenses above an income-related threshold, note 275 supra, would thus be considered as part of the basic policy determination on appropriate coverage. Similarly determined by the basic 
But, while it needs considerable elaboration to deal with such problems as defining categories, making eligibility determinations, and guarding against fraud, it promises to reward further examination. At the very least, it dramatizes the policy dilemma presented-namely the need to protect individuals in widely varying economic circumstances against medical-financial catastrophe without issuing additional blank checks to the providers of hightechnology medical care. It also suggests a way of keeping government from becoming a central participant in the extraordinarily difficult but inevitable decisions in the borderland between life and death.

\section{The Universal Fixed-Budget Approach}

Despite the demonstrable advantages of giving patients substantial decisionmaking and some cost-sharing responsibility, many observers may still prefer an allocative system in which providers, not patients, face resource constraints. ${ }^{282}$ This entails setting a fixed budget with which providers must meet the health needs of a defined population. Denied the customary assurance that all services rendered will almost certainly be paid for on a fee-forservice or cost reimbursement basis, providers operating under a fixed budget have to adopt and adhere to priorities in their use of resources. This means of altering provider behavior underlies the HMO concept, as discussed

coverage would be whether certain illnesses were included, note 276 supra-presumably with some less "worthy" but expensive ones excluded. Degree of disability, note 277 supra, could be handled as a matter of indemnity amount, note 280 supra, rather than one of eligibility. Such an alternate approach might be simpler to administer, but would probably control costs somewhat less well and require somewhat broader government involvement than the text's plan.

282. Policy analysts who are skeptical of emphasizing patient prerogatives and responsibilities often point to the following concerns, among others:- 1) Patients are ill-informed about and poorly equipped for medical decisionmaking and are therefore unable to balance costs and benefits effectively; overcoming these problems is either impossibly complex or excessively costly (if only in increased physician time). 2) Patients who seek medical help are not entering into an arm's length commercial transaction but rather are seeking counselling from a fiduciary, with whom they are unprepared to bargain as they would with other service providers; this mindset is exacerbated by the dependency and anxiety that naturally accompany illness and a patient's decision to seek treatment. 3) Catastrophically ill patients are unlikely to have a rational perspective in coping with their medical problems. Not only may desperately ill patients seek the reassurance of virtually any treatment, but their other priorities will also necessarily pale in comparative importance-in short. decisionmaking by critically ill patients lacks the requisite element of true choice because of the extraordinary exigencies of catastrophic illness. 4) Finally, the medical marketplace is so imperfect because of monopolistic physician dominance-gained from supply curtailment, hoarding of knowledge, social norms of physician omniscience, and competitive barriers imposed by professional norms and referral patterns-that reliance on patient sovereignty is unrealistic and doomed to be ineffectual. Those who stress these factors typically advocate reliance on some form of government regulation, such as health planning-cum-regulation or utilization review through such bodies as PSROs.

However, incremental emphasis on patient prerogatives and responsibility does not mean abandonment of other techniques of social control. The fixed-budget approach discussed in the text, for example, attempts to accommodate skepticism toward patient autonomy by examining a nonregulatory approach that relies primarily on providers rather than government regulators to make allocative choices 
earlier, ${ }^{283}$ but it could also be implemented on a system-wide basis, as is done in the United Kingdom and as is proposed in the Kennedy-Corman Health Security bill. ${ }^{284}$ The implications of a universal fixed-budget strategy go well beyond the scope of this paper's investigation of catastrophic care financing, but, setting the larger issues aside, ${ }^{285}$ it is useful to consider how well such a system might address the problem of controlling the cost of treating catastrophic disease.

The fixed-budget approach assigns the legislature the task of assessing societal priorities at a macro level ${ }^{286}$ and earmarking a specific sum for health care, which is then allocated among the myriad health services by a mixed professional, managerial, and political process. In this process, the lifesaving imperative would surely operate, but its impact would be softened because many important investment and budgeting decisions would be made in advance, affecting patients who are only unknown, future statistics and not identified individuals. Moreover, the fixed budget would compel many decisions to be framed in "either-or" rather than "yes-no" terms, greatly improving prospects for cost-control effectiveness. For these reasons, the fixed-budget approach would help achieve the goal of insulating government from direct responsibility for the system's inability to effect cures in specific cases and would almost certainly lead to substantially more effective overall cost control than is achievable under open-ended government financing.

Despite these virtues, a universal fixed-budget system would not guarantee the achievement of optimal resource allocation between catastrophic and

283. The experience of HMOs, section III.B.3. supra, shows this effect. Prospective reimbursement of hospitals is a similar prepayment strategy. See, e.g., Public Health Service, U.S. Dep't of Health, Educ. \& Welfare, Forward Plan for Health, Fy 1978-82 at 34 (Aug. 1976); V. Fuchs, supra note 11, at 100-02. See also Roemer, On Paying the Doctor and the Implications of Different Methods, 3 J. Health \& Human Behavior 4 (Spring 1962).

284. The governmentally operated Veterans Administration (V.A.) system is a functioning American example of system-wide resource allocation through an estimated budget, negotiated in advance. V.A. behavior may, however, be atypical of pre-budgeted systems' effectiveness in containing outlays because it lacks institutional incentives for reducing costs. Moreover, the political funding debates often take on military and patriotic, rather than health-related, dimensions. See Sapolsky, America's Socialized Medicine: The Allocation of Resources Within the Veterans' Health Care System, _ Public Policy — (1977). The V.A. is nonetheless worthy of policymakers' attention, since it is the closest model to a publicly operated comprehensive health care delivery system that currently exists in the United States. See generally Lipsky, McCray, Prottas, \& Sapolsky, The Future of the Veterans' Health Care System, I J. Health Politics, Policy \& Law 285 (1976).

285. See, e.g., Donabedian, Issues in National Health Insurance, 66 Am. J. Public Health 345, 345 (1976): "Those who wish to reform the system have a broader range of objectives which include protective efficacy, cost control, quantitative adequacy, qualitative adequacy, efficiency of production, efficiency of allocation, equity, and redistribution of capacity. . . The provision of comprehensive benefits generates the necessity for a fundamental change in the organization of health services ...."

286. See text accompanying notes 131 \& 132 supra for an explanation of "macro" versus "micro" approaches. 
other health needs. Even though Britain's overall commitment to health services has been impressively, even oppressively, controlled by central dictation of the National Health Service's budget, ${ }^{287}$ only recently, under extreme fiscal pressure, has significant rationalization of resource allocation even begun. ${ }^{288}$ Even so, many observers feel that relatively too much is still spent on catastrophic care and too little on other pressing health needs. ${ }^{289}$ The problem would likely be more acute in the United States, where the public is already accustomed to much greater medical spending and higher technology and where it is unlikely that comparably draconian budget limits would be imposed because of the commitment to the lifesaving imperative. Although it is at least arguable that the Health Security fixed-budget model might achieve a better balance between catastrophic and other care than has yet been achieved in Britain-if only because it contemplates broader responsibilities for PSROs, utilization-control institutions beyond anything employed in the United Kingdom ${ }^{291}$ - it is unlikely that patient or societal preferences would prevail in the face of medical dominance and the symbolic values of the lifesaving imperative in allocative decisionmaking. ${ }^{291}$ Under these circumstances, a unitary, governmentally financed system is likely to compromise or neglect the public's legitimate interest in cost control and in receiving nonmedical health services.

287. The British system has been relatively successful at holding down costs and has been described as "probably one of the cheapest in the world." Cooper, supra note 155, at 104. In 1974 a parliamentary committee concluded that "no Government has ever provided sufficient money" for health. "As a result of the inadequacy of finance, the service is grinding to a halt." House of Commons, Public Expenditure Comm. (Social Services Subcomm.), 4th Report, Sess. 1974. Expenditure Cuts in Health and Personal Social Services, HMSO, 1974 (HC 307) [hereinafter cited as Public Expenditure Comm.], cited in Klein, The National Health Service, in Inflation and Politics 83, 86 (R. Klein ed. 1975).

288. See Dept. of Health and Social Security (U.K.), Priorities for Health and Personal Social Services in England 1 (1976) [hereinafter cited as Priorities]. See also The British Health Care System 144-46 (Prepared by Economic Models, Lid., London, for the Am. Med. Ass'n, 1976); R. Crossman, supra note 100, at 11-17, 26-28; Klein, supra note 287, at 88-92. Indeed, the very expression "resource allocation" is in Britain taken to mean the "distribution of financial resources" among different localities, not how the money is spent. Resource allocation Working Party, Dept. of Health and Social Security, (U.K.), Sharing ReSOURCES for Health in ENGLANd 8 (1976).

289. See, e.g. Public Expenditure Comm., supra note 287; see also Priorities, supra note 288, at 1; Lister, By the London Post: Bleak Outlook, 294 New ENG. J. MEd. 1224 (1976); note 100 supra.

290. One important British consultative document, while noting the importance of efficiency as well as quality in medical practice, concludes that clinical practice "must continue to be the responsibility of the clinicians concerned." Priorities, supra note 288, at 28. See also Anderson, All Health Care Systems Struggle Against Rising Costs, Hospitals, Oct. 1, 1976, at 97, 102.

291. PSROs could be expected to be more effective in allocating a fixed budget than in controlling costs under the present system of open-ended financing. PSROs' structure and orientation, however, would probably still leave considerable scope for medical politics and would allow medical rather than societal or patients' personal values to predominate. Nor would adding a consumer influence to PSROs solve the problem, since the difficulty lies in giving organized medical interests the high ground and conceding their legitimacy as spokesmen for patient interests. 


\section{VI}

\section{Conclusion: The Pluralistic Approach}

The often harrowing dilemmas created by the necessity to limit the commitment of societal resources to catastrophic care suggest that there is probably no one right way to solve this problem for all people at once. Much turns on personal values and preferences. From this point of view, the principal weakness of comprehensive national health insurance plans, such as the Health Security proposal, is that they would centralize financing and attempt to settle politically upon a single standard of care for everyone. ${ }^{292}$ They would thus remove the necessity for cost-constrained expression of the widely divergent preferences of individuals with respect to medical care generally and catastrophic care in particular. These preferences reflect varying degrees of confidence in what doctors can $\mathrm{do}^{293}$ and a wide range of personal values and circumstances. People vary greatly both in their fatalism and stoicism about various qualities of life and health and in their preferences between such things as security and risk-taking, institutional and home care, and hightechnology medicine and procedures less offensive to personal integrity and dignity. ${ }^{294}$ By removing willingness to pay both for coverage and for services as a measure of the strength or weakness of such preferences, and also by denying individuals the opportunity to benefit from their economizing choices, comprehensive national health insurance plans would invite both overspending for those with preferences for elaborate health services and nonprice rationing unfair to those with a desire to purchase more or better care. As we have argued, political processes dominated by the medical profession and the lifesaving imperative are poorly adapted to making choices with potentially tragic consequences, leading to a systematic bias toward more spending on catastrophic care than cost-conscious but nonnecessitous consumers would elect on their own.

292. Although the bill does not detail the quality regulation it would require, its objective is "to require the highest practicable quality of care that is attainable in substantially all parts of the United States. Exceptions ... shall be permitted only when necessary to avoid critical shortages of services. . ." S. 3 \& H.R. 21 , 94th Cong., lst Sess., \$ 141(b) (1975) in 1975 Hearings, supra note $4 \mathrm{l}$, at 475 . It is, of course, unknowable whether in practice the single governmental standard might ultimately prove too low or too high for most people. Cf. Klein, supra note 287, at 85 (Britains low proportion of GNP spent for health care may indicate either too low priority or successful cost containment).

293. See. e.g. McNerney. The Quandary of Quality Assessment, 295 New Eng. J. Med. 1505 , $1506-07$ (1976).

294. Various religious groups, for example, hold distinct positions on the use of certain medical procedures or on questions like the desirability of prolonging dying patients' lives. Rather than seek a false social consensus, it may be easier and wiser to allow different groups to reach their own conclusions and bear the consequences themselves. Such questions are likely to become progressively more acute as biomedical technology expands our capacity to maintain life after health and to rearrange genetic and physiological processes previously beyond our reach.

Starr, A National Health Program: Organizing Diversity, Hastings Ctr. ReP. Feb. 1975, at 11,13 
An attractive alternative may be to eschew trying to solve the problem in any definitive fashion and instead to take steps to enhance each individual's ability to solve his own personal problem by choosing among a variety of available options, with public financial assistance where necessary. Such a strategy lacks the tidiness and specificity which policymakers often desire and would doubtless leave many residual problems for regulators and the courts to grapple with. But the fundamental values of pluralism and freedom, as recognized in such constitutional precepts as the right of privacy, suggest an obligation not only to tolerate but also to foster diversity on matters as intensely personal and private as the means of coping with life-threatening disease and the attendant tragic choices. Something like the positive program sketched below for improving catastrophic insurance coverage may well offer the best chance for resolving the allocative and ethical dilemmas which this article has identified. Because dilemmas of this kind are implicit in all medical care, though in lesser measure, the catastrophic disease problem may fairly be regarded as the hardest case, and a proposal which addresses it effectively should have value for dealing with the health sector's broader allocative problems as well.

The basic, well recognized need to widen the population's financial protection against medical-financial catastrophes can be met in a variety of ways consistent with limiting government entanglement and avoiding enforcement of a false consensus on surrounding issues. One promising approach is based upon a relatively simple change in the tax law. The current subsidies for health insurance premiums implicit in the tax law's definition of income and wages and in the medical deduction would be replaced by a limited credit against personal income taxes for premiums paid by either employer or employee. ${ }^{295}$ In addition to benefiting most taxpayers more than the tax ad-

\footnotetext{
295. Many congressional bills are of the tax-credit variety. One summary lists five such bills (of eighteen summarized in all). DHEW Summany, supra note 41. A major recent academic initiative for "kiddie-care" and catastrophic coverage would also use tax credits. Marmor. Rethinking National Health Insurance, 46 PUB. INT. 73, 89-94 (1977). Many analysts generally oppose such use of tax credits (and similar devices) to effect social or political goals through hidden, indirect spending (loss of revenue) rather than direct appropriations, which must be regularly and openly debated. E.g. S. Surrey, Pathways to Tax Reform (1973). In defense of the proposed credit. it should be noted that the fiscal impact of such tax subsiclies need no longer be hidden. The concept of "tax expenditures" was formally introduced in 1968. U.S. Dep"T of the Treasury. Annual Report of the Secretary of the Treasury on the State of the Finances $322-40$ (1969), and allows such expenditures to be analyzed along with normal appropriations. But of. Bitter, Accounting for Federal "Tax Subsidies" in the National Budget. 22 Nar'L TAx J. 244 (1969) (expressing concern about the "tax expenditure" concept), a reply by Professors Surrey and Hellmuth, id. at 529, and a rebuttal by Professor Bittker, id, at 538. Moreover, the Congressional Budget Act of 1974, Pub. L. No. 93-344, tits. I-IX, 88 Stat. 297 (codified in scattered sections of 1,2 and 31 U.S.C.), requires the President to include tax expenditures in the Budget, id. $\$ 601$, 31 U.S.C. \& 11 (Supp. IV 1974), and has created the mechanisms for Congress regularly to review such expenditures. Also the exact cost of the proposed tax credit would be far easier to compute than that of the current exclusion from income and deduction approach. Finally, it is
} 
vantages lost (so as to make the change politically attractive), the maximum credit should be at least sufficient to permit purchase of substantial catastrophic coverage $\mathrm{e}^{\mathbf{9 6}}$ — with cost sharing no greater than an acceptable proportion of annual income. This would have at least two important effects:

1) Greater emphasis on catastrophic as opposed to "shallow" coverage. Limiting the credit would put people in the position of spending their own after-tax money to get extra coverage or broader benefits. This would help curb the current tendency toward overinsuring against modest and predictable medical expenses in order to pay such bills with untaxed dollars. People could be expected to concentrate instead on spending the credit on essential protection, particularly against catastrophic risks. If policymakers lacked confidence that the public would indeed come increasingly to prefer catastrophic coverage, further government steps to deal with the "free rider" problem would be justified: Certain minimum standards could be set for the insurance policies and other plans whose premiums would be eligible for the credit. Or an attractive public income replacement plan could be offered to induce purchase of adequate catastrophic coverage ${ }^{297}$ Finally, catastrophic coverage could be made compulsory, as auto insurance now often is.

2) Expanded catastrophic coverage for the poor and near-poor. Under the suggested tax change, everyone, including those currently uninsured, would be guaranteed adequate coverage by a $100 \%$ tax subsidy up to the maximum amount of the credit. Those with insufficient tax liability to absorb their credit could be given a cash rebate or an insurance voucher of equal or greater value. Appropriate arrangements for subsidizing noncatastrophic coverage of lower-income persons should also be made.

Of course, changing the tax law would not solve the problem of controlling costs in the treatment of catastrophic disease; indeed, without more, the expected expansion of private catastrophic insurance coverage could exacerbate the problem. Nevertheless, by making additional premiums wholly aftertax expenses, the tax change would, to some extent, increase customer resistance to premium increases, and insurers and other plans would feel greater pressure to provide cost-effective coverage and to find effective and acceptable means of controlling costs. A recent study by the Council on Wage and Price Stability suggests that the private sector's present incentives-and its ability-to contain costs have been significantly underestimated. ${ }^{298}$ A shift to

difficult enough to postulate the removal of current tax subsidies of medical care even supposing the credit as a replacement subsidy; without the credit, changing the tax law would be politically inconceivable.

296. A variety of "Major Risk Insurance," supra note 42, could be one such plan, although this paper does not mean to endorse any of Professor Feldstein's suggested versions. Other possibilities are discussed in sections V.A. \& B. supra.

297. See section V.B. supra.

298. Council on Wage \& Price Stability, Executive Office of the President, The Com- 
limited tax credits would strengthen the existing incentives and stimulate added cost-control endeavors.

Effective cost containment could also be facilitated by easing the current restrictions on insurers and other financing entities (including HMOs) which unduly limit their ability to influence physician decisionmaking on a wide variety of matters affecting costs. Indeed, a truly pluralistic approach to problems of health care costs and of catastrophic disease would require that financing plans and their members have reasonably wide discretion as to what services will be covered and how care will be provided. Current state restrictions on the "corporate practice of medicine" by health plans should therefore be narrowed if necessary to permit active cost-containment initiatives to be taken. ${ }^{299}$ Plans would then be in a position to obtain meaningful recognition by providers of patients' collective interest in cost-effective allocation of resources. The predictable professional resistance to many of the measures which might be taken could be curbed by appropriate application of the antitrust laws. ${ }^{300}$

With the tax incentives for overinsurance and legal and professional im-

Plex Puzzle of Rising Health Care Costs: Can the Private Sector Fit It Together? (1976). See Havighurst, Controlling Health Care Costs: Strengthening the Private Sector's Hand, 1 J. HEalth Politics, Policy \& Law 471 (1977).

299. The common law rule that a corporation cannot engage in a "learned profession" has been supported as a protection of professional services against lay interference or commercial exploitation. See, e.g., Laufer, Ethical and Legal Restrictions on Contract and Corporate Practice of Medicine, 6 LAW AND Contemp. Prob. 516 (1939). The "corporate practice" rule may not be a significant problem except for HMOs which do not qualify under the federal HMO Act and therefore do not benefit from the "override" provision which exempts qualified HMOs from such restrictions in state law. 42 U.S.C. $\$ 300 \mathrm{e}-10$ (Supp. IV 1974). See also Note, The Role of Prepaid Group Practice in Relieving the Medical Care Crisis, 84 HARv. L. REv. 887, 960-62 (1971) (HMOs' problems before the HMO Act). Insurers should have no problem because they do not undertake to provide medical care and insured patients contract directly with doctors without any intermediary. So long as insurers' cost-control efforts are confined to defining the coverage of their plans, see text accompanying notes 301-03 infra, no question of corporate practice should arise. Thus, coverage could even be limited to a group of doctors who had accepted an insurer's fee schedule and agreed to follow the insurer's procedures for establishing its payment responsibility. The critical feature would appear to be whether patients and doctors were free to make arrangements for care not covered by the insurance plan. Cf. Havighurst \& Blumstein, supra note 5, at 54-58 (arguing that PSROs are engaged in defining Medicare-Medicaid coverage, not regulating medical practice).

300. Antitrust principles would of course prohibit medical societies from organizing formal boycotts. Radiant Burners, Inc. v. Peoples Gas Light \& Coke Co., 364 U.S. 656 (1961) (per curiam); Klor's, Inc. v. Broadway-Hale Stores, Inc., 359 U.S. 207 (1959); Fashion Originators' Guild of America, Inc. v. Federal Trade Commission, 312 U.S. 457 (1941). They would also prohibit concerted actions calculated to stimulate collective pressure on the initiators of unwanted cost controls. Cf. Eastern States Retail Lumber Dealers' Ass'n v. United States, 234 U.S. 600 (1914) (information exchange prompting refusals to deal unlawful). The AMA was recently counseled-correctly, it would seem-not to issue a prepared statement attacking certain costcontrol strategies being adopted by insurers. 'Second Opinion' Statement Weakened, Am. Med. News, Dec. 13, 1976, at 12, cols. 2-3. See Havighurst, The Role of Competition in Containing Health Care Costs, a paper prepared for the Federal Trade Commission, Conference on Competition in the Health Care Sector: Past, Present, and Future, Washington, D.C., June 1-2, 1977. 
pediments to cost control eliminated, consumers desiring health care insurance would no longer be induced to purchase only plans providing more or better (or different) health services than they in fact want. A fuller menu with more opportunities to economize would be offered. It is impossible to imagine or set forth all of the possible offerings or all of the methods by which plans might give each consumer or group just the desired amount of protection against the risks of catastrophic disease. Nevertheless, some possibilities are listed below in order to convey a sense of the multiplicity of possibly workable and acceptable approaches. That one can debate, perhaps endlessly, such issues as the cost-effectiveness and ethical implications of each approach in a variety of particular circumstances is simply evidence of the desirability of decentralizing decisions about their respective merits and avoiding adopting any of them in a single universal plan.

1) Specific exclusions from coverage. Plans could elect to exclude highly discretionary or medically questionable procedures from basic coverage, provided such exclusions were disclosed as explicitly as possible. A set of procedures that a particular plan might consider more discretionary and budgetable and of less absolute importance-possibly including coronary bypass surgery, total hip replacement, and organ transplants, at least at the present state (and cost) of the art ${ }^{301}$-could be sold as supplemental coverage, although problems of self-selection by high-risk purchasers could necessitate high risk-related rates and perhaps physical exams, as with life insurance.

2) Utilization controls. Plan-initiated utilization controls are similar to coverage limits but normally operate case by case to exclude procedures which do not lend themselves to blanket exclusion in advance. ${ }^{302}$ Such controls could be appropriately tailored to reflect the expectations of the subscribers to a particular plan and could differ substantially in their leniency or stringency from those imposed by PSROs. As under PSROs, reviewers would monitor the steps taken in treating particular patients, assuring that appropriate settings and treatments were chosen and that questionable procedures were not reimbursed. Plans with unreasonable or poorly administered controls would have trouble in attracting and keeping both consumer patronage and provider cooperation. Individuals would of course be free to purchase things which the plan found not of sufficient priority or value to be reimbursed. So structured, utilization controls might well prove to be a frequently used option.

3) Policy limits and cost sharing. A plan might set up an upper limit on lifetime catastrophic benefits. ${ }^{303}$ Plans could also use cost sharing to discourage overutilization of certain kinds. Creative use of cost sharing might also include, for example, higher rates for questionable procedures or for smokers

301. See note 110 supra.

302. Quality controls could likewise operate to review the necessity for and value of certain modes of diagnosis or treatment.

303. See text accompanying notes 260-63 supra. 
or others whose health problems are partly self-inflicted.

4) Income replacement plans. Plans might not only cover medical care but also provide income replacement, particularly as a means of making more extensive cost sharing or stricter coverage limitations feasible. The promise of this intriguing approach would be most effectively explored in a pluralistic context. ${ }^{304}$

5) Fixed-budget proziders. The fixed-budget approach to resource allocation would certainly be a major item on the menu. Earlier discussion highlighted a major difficulty encountered by one such provider, HMOs, in treating catastrophic disease-namely the need to adhere to customary practice. ${ }^{305}$ If, however, clearly announced and reasonable deviations from prevailing standards and style of practice were legitimized-through contractual arrangements, for example-this problem could be overcome. A promising alternative model of prepayment has recently been proposed: promoting cost-effective, quality care through prepaid "Health Care Alliances (HCAs)," initiated by insurers. ${ }^{316}$ Each HCA would be "a limited set of hospitals and doctors who have been designated by the insurer to function as an economic unit," ${ }^{307}$ providing comprehensive care to a defined, voluntarily enrolled population and competing for subscribers with a number of HCAs, HMOs, and other plans in a given community.

HCAs differ from HMOs in that insurers rather than providers bear the financial risks. Yet, as in HMOs, but not in the insurance programs discussed thus far, HCA providers are expected to function as a group, helping to control one another's utilization of resources in order to maintain their plan's competitive viability. The qualitative and cost advantages achieved could also supply competitive pressure on other plans. Because of the ability of these plans to select and influence physicians and because of the decentralized, competitive nature of a system featuring many HCAs and HMOs, such a system would probably achieve much greater alterations in physician behavior and in resource allocation between catastrophic and ordinary care than would a highly politicized universal fixed-budget system. The prepaid comprehensive model is not, however, easily adapted to provide only catastrophic care.

Given such a varied menu of plans and controls, an obvious concern would be whether consumers were making reasonably informed choices and whether the bargains being entered into in buying catastrophic coverage were fair ones. Nevertheless, there are grounds for optimism. First, most purchases of catastrophic coverage would probably continue to be made in employment

304. The multiplicity of possible income replacement plans, section V.B. supra, provides an argument for private diversity in this area.

305. See notes 139-4l supra and accompanying text.

306. P. Ellwood \& W. McClure, Health Delivery Reform (InterStudy, Oct. 25, 1976) (summarized in Health Services Information, Nov. 1, 1976, at 2).

307. Id. at 4 . 
groups, despite the tax change. Groups can hire outside experts and otherwise bring considerable sophistication to bear and supply substantial assurances of fairness. Moreover, despite the arguable ignorance of the average consumer, competition normally forces competitors to cater to the betterinformed marginal customers, particularly those organized in sophisticated groups. Efforts by health plans to attract or retain those who are most likely to join or leave and who are most alert to differences among plans should assure that a reasonable balance between quality and cost is maintained for the benefit of all. ${ }^{318}$ Finally, many plans would probably adopt a policy of close consultation with plan members as a means of deciding on, and legitimizing, otherwise troubling restrictions on payment for catastrophic care. This would allow decisions to be made by those who are most directly affected and who must pay the cost. Consumer participation would also help clarify and publicize the issues so that members unhappy with the outcome would know to seek an alternative. The federal HMO Act already requires membership participation in such policy decisions by HMOs, ${ }^{319}$ but plans organized under different authority would probably find that developing consultative channels would not only enhance their marketability but perhaps strengthen their legal position as well.

Despite these substantial safeguards, many observers would probably still feel the need for comprehensive regulation to protect consumers against abuses. Although the lifesaving imperative might well distort the outcome if such regulation were too extensive, some oversight could be beneficial. State insurance commissioners, for example, might promote some standardization (though, one hopes, not too much) and could provide some additional assurance that the plans' cost-control features were not unfair. ${ }^{310}$ The courts, too, would exercise oversight in deciding whether to recognize and enforce limits on plans' commitments. Courts are familiar in other contexts with problems of consumer ignorance, sellers' overreaching, unconscionability, and "contracts of adhesion"-in short, with the problems of policing the institution of private contract to promote fundamental fairness. Courts should be able to distinguish reasonably well between abuses and rational choices about the quantity and type of health services to be provided at insurer expense when catastrophic disease strikes. It is perhaps also reassuring that a patient who exhausted his benefits would continue to have a degree of informal protection in providers' unwillingness to terminate treatments instantaneously and in the

308. Special problems would be created by plans catering almost exclusively to disadvantaged groups, at the same time more in need of services (and therefore more expensive to insure) and less able to switch from one plan to another.

309. 42 U.S.C. $\$ 300 \mathrm{e}(\mathrm{c})(6)$ (Supp. IV 1974).

310. It might be thought desirable, for example, to follow the lead of California's Natural Death Act, supra notes 194-98, in banning any requirement that subscribers sign "living wills," supra note 193, or any denial of coverage to nonsignatories-although an actuarially reasonable premium differential would not be unfair. 
obligation that most of them feel to treat sympathy-arousing cases without charge. $^{311}$

A diversified system might use any or all of the foregoing methods to balance the needs for catastrophic disease protection and for cost containment, but this list is obviously not exhaustive. ${ }^{312}$ Nor does it present any single, ultimately satisfying means of resolving the tragic choices inherent in catastrophic medical care. There would surely be imperfections, but these would at least not be universally imposed by government and might even prove self-limiting. What the pluralistic approach does accomplish is to avoid making the wrong choice of strategy or freezing our entire societal approach to health care into one irrevocable mold. ${ }^{313}$

We must face facts: We do not know where future medical technology will take us or even what priority much of current medical practice is really assigned by different people in our society. Accepting a pluralistic approach would allow experimentation and not preclude future changes. Precisely because this approach contains elements of all the others and does not limit people's options or opportunities for future elaboration, it may well be the most promising one available for beginning to deal with the truly intractable, indeed tragic, dilemmas of responsibly financing catastrophic medical care.

311. See notes $17 \& 268$ supra and accompanying text. Some further care might also be made available in public institutions.

312. Another potential innovation by third-party payers would require all professional services to be billed and approved by a primary physician except in unusual cases. The goal would be to subject the very expensive services of specialists and subspecialists to a form of peer review by their more generalist colleagues who make referrals to them. Physicians' ethics and tradition currently require that patients (and their insurers) deal with every provider individually-on the theory that an inviolate doctor-patient relationship exists for every medical service. See AMA Principles of Medical Ethics passim (Opinions \& Reports of the Judicial Council, Am. Med. Ass'n 1971). ( $\$ 7(2)$ provides: "[E]ach physician should submit a bill for the service he has himself rendered and receive payment therefore [sic] directly from the patient.") No matter how artificial this may seem when compared with actual practice (as where, for example, pathologists perform laboratory tests for patients never seen), direct billing is apparently adhered to almost universally, effectively bypassing the potential scrutiny of the primary care provider who has ordered the service or made the referral and who should, after all, be expected to provide overall continuity in patient management. If third-party payers would accept only a single professional bill, then primary physicians might be expected to honor their fiduciary obligations to patients by exercising a restraining influence on excessive procedures or particularly high charges. At the least, primary care providers would become more aware of specialists' practices and fees-information which could help guide future referrals.

In this model, primary care physicians are analogous to general contractors, who monitor subcontractors' cost and quality performance for their "clients," just as primary care physicians should be encouraged to oversee specialists on referral. The principle of primary physicians' responsibility and concomitant accountability for cost and quality assurance is a potentially valuable sources of improved medical "productivity," although the model would naturally prove impractical in some cases (like emergency care). Equally naturally, specialists would vociferously oppose any such challenge to their independence, and many generalists would worry about unethical practice, potentially enlarged malpractice liability, overwork, and their competence to review the work of specialists. The proposal would have undoubted appeal, however, for those seeking to enhance the prestige of today's outnumbered, low-status primary care providers.

313. For a student of the case for a pluralistic approach to the problems of the health sector generally, see Havighurst, supra note 298. See also Blumstein \& Zubkoff, supra note 37. 